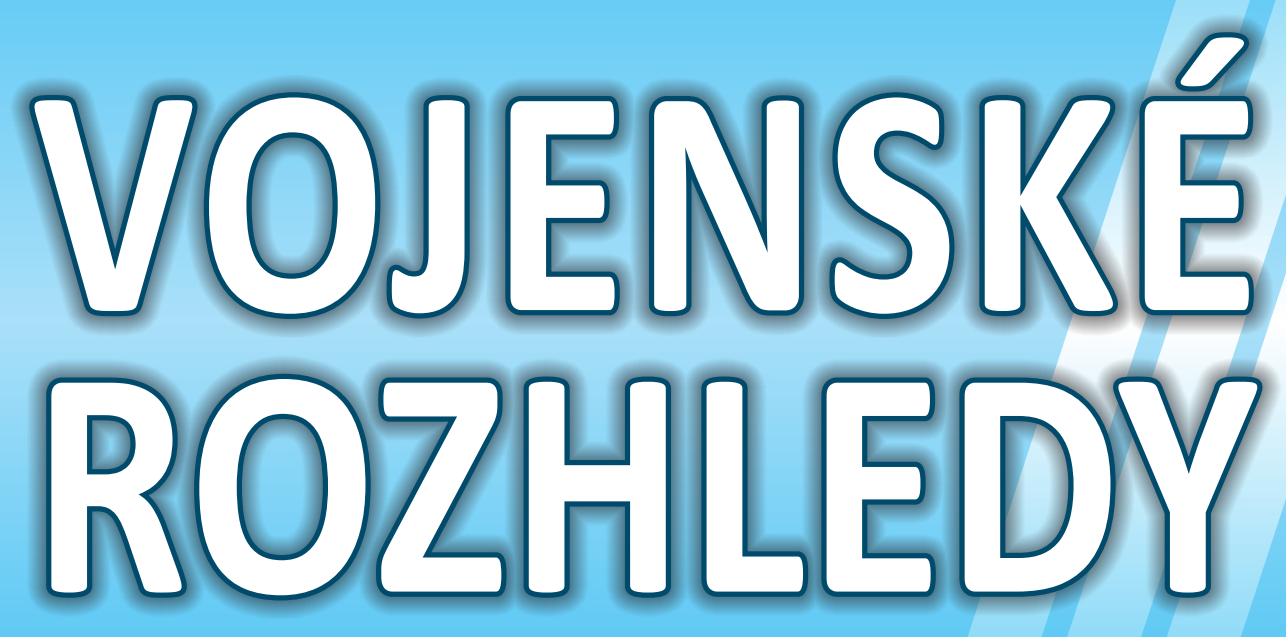

Czech Milijitary Review
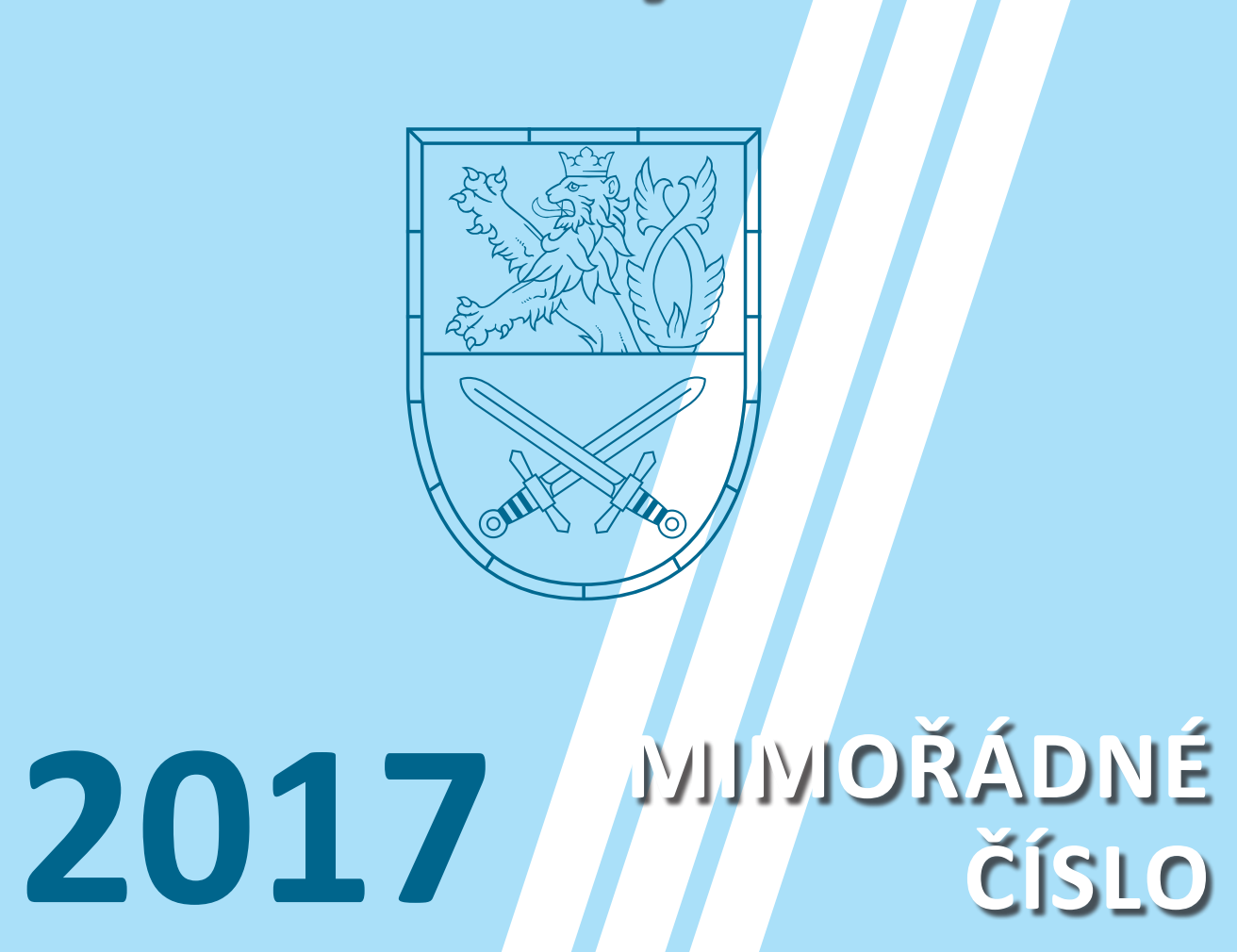


\section{VOJENSKOTEORETICKÝ ČASOPIS}
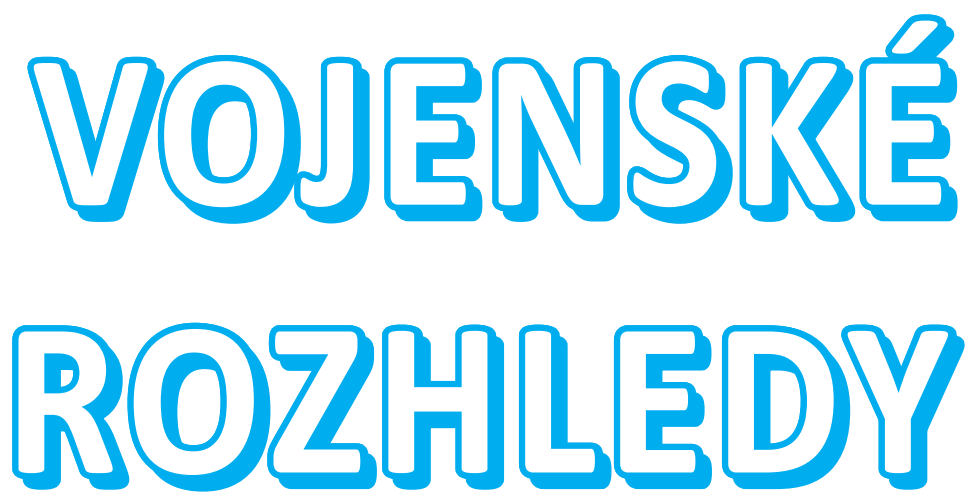

\section{Mimorádné číslo}

ROČNÍK 26 (58) 



\title{
Institutionalisation of the Analytical Support Function to Ensure Credibility of Defence Management - Canada, Norway, Sweden and NATO Case Study
}

\author{
Institucionalizace funkce analytické podpory pro potřeby \\ důvěryhodného řízení obrany - případová studie Kanada, \\ Norsko, Švédsko a NATO
}

\section{Josef Procházka}

Abstract: The paper outlines several recommendations for strengthening the institutional framework of the analytical support function for credible defence management. Recommendations are drawn based on the outcome of the institutional research project named Strategic Alternatives conducted by the Centre for Security and Military Strategic Studies of University of Defence (CSMSS). The multi-objective research focuses on organisational arrangement of the analytical support function within the overall ministry of defence organisational architecture of several countries (Canada, Norway, Sweden) as well as the NATO structure and management (in this case, the main focus embraces the analytical support to defence planning).

Abstrakt: CClánek doporučuje některé přistupy pro posílení institucionálního rámce analytické podpory za účelem zvýšení důvěryhodnosti řízení obrany. Doporučení jsou výsledkem výzkumu, který byl proveden Centrem bezpečnostních a vojenskostrategických studií Univerzity obrany (CBVSS) v rámci dlouhodobého záměru rozvoje organizace s názvem Strategické alternativy (STRATAL). Výzkum byl zaměřen na organizační uspořádání funkce analytické podpory v rámci celkového organizačního uspořádání ministerstev obrany několika vybraných zemí (Kanada, Norsko a Švédsko) a v rámci organizační struktury NATO ( $v$ tomto prípadě byla pozornost zaměřena především na analytickou podporu obranného plánování).

Keywords: Analytical Support; Defence Management; Military Decision Making Process; Credible Defence; Institutional Framework.

Klíčová slova: Analytická podpora; rízení obrany; vojenský rozhodovací proces; důvěryhodná obrana; institucionální rámec. 


\section{INTRODUCTION}

There is an even greater need for sound defence management today than at any time since the dissolution of the Warsaw Pact. The combined effect of resurgent Russia and security pressures from radical extremists coupled with the ongoing national austerity measures present new and growing security challenges for allies and partners. When you couple these new challenges with the emergence of new warfare tools, such as cyber capabilities and greatly enhanced electronic warfare capabilities, enabled by rapid advances in the nation's ability to process information, the security environment becomes more complex than at any time in the past. Two additional elements that add complexity to the capability development are the rise of commercial products and capabilities and the shortening of the technological maturation cycle, both of which change the security environment for most nations. The ability to harness the commercial opportunity in military capabilities is critical for future security. Simply, greater complexity coupled with the rise of a potential near-peer and a challenged resource pool leave all allies and partners in a situation where more, not less, analytical support and research collaboration is needed. ${ }^{1}$

Additionally, the provision of defence is inevitably related to the process of making hard choices in terms of resources allocated to the development of capabilities or people's lives and the potential of material damage in relation to the employment of force in operations. In order to ensure a convincing degree of defence credibility, the decision making process must maintain its objectivity and rational nature. It means, for example, that defence policy objectives should be set right and implemented in the right way. The state's defence policy should be the most rational (the most reasonable) policy of the state, because, in case of its failure, the existence of the state is threatened. It is a paradox, however, that in everyday practice, this perfectly reasonable policy of the state is very often built upon the background of irrational inputs, permanent lack of information and subjective factors. ${ }^{2}$ It means that effective and efficient defence policy formulation and its implementation via sound strategic management framework require the most comprehensive and objective information and inputs into the decision making process. This is understood as an evidence-based decision making.

1 Science and Technology Organisation Collaborative Programme of Work and Budget for Year 2016. NATO Science and Technology Organisation, Collaborative Support Office, BP 25, F 92201 NEUILLY-SUR-SEINE - FRANCE. 5 February 2016. p. 1.

2 FRANK, Libor; PROCHÁZKA, Josef. Scenarios and Capability Planning: Creation of Scenarios as a Tool for Predicting the Future Operating Environment. Strategos, 2017, vol. 1, no. 1, pp. 69-82. ISSN 2459-8771. Available at: http://strategos.morh.hr/wp-content/uploads/2017/03/LiborFrank-and-Josef-Prochazka.pdf 
Therefore, the modern defence sector management benefits from a sound analytical support function (ASF). The point of departure for justification of the ASF is actually the definition of managerial functions. ${ }^{3}$ The recognised main managerial functions include planning, organizing, staffing, directing, and controlling. However, there are also supporting managerial functions, which embrace analysing, decision making and communication. ${ }^{4}$ It means, in fact, that without proper analysis, decision making and communication the management model of any given organisation would be rather incomplete. This fact could put the functioning of this organisation under a considerable level of risk. ${ }^{5}$

With regard to the role the analysis plays at the Czech MoD, the situation is not very positive. Based on the data acquired in the research entitled "Solving Unstructured Decision-Making Problems in the Czech MoD", it was obvious that the utilization of the strategic analysis methods in this organization is not at a high level. Based on the performed research, there is a lack of utilization of the existing and relevant methods, little knowledge about their proper application and a number of barriers which complicate their effective use. ${ }^{6}$

The author of this article argues that proper institutionalization of the ASF in accordance with the best practices applied by several NATO allies and partner nations will enhance the quality of strategic defence management within the MoD of the Czech Republic and effectiveness of decision making process in the area of defence provision.

The objective of this contribution is to define the ASF and identify its necessary organisational framework, including its mission and areas of interest. The findings presented in this article are outcomes of research spanning several years of analysis encompassing organisations, which might be considered as champions in this area, taking into consideration the wider NATO context (allies and partners). ${ }^{7}$

3 VODÁČEK, L., VODÁČKOVÁ, O. Modern Management in Theory and Praxice (Moderní management $v$ teorii a praxi). 1. Edition. Prague: Management Press, 2006. 295 p. ISBN 807261-143-7.

4 NORMAN, Leyla. What Are the Four Basic Functions That Make Up the Management Process? Available at: http://smallbusiness.chron.com/four-basic-functions-make-up-managementprocess-23852.html

5 GRASSEOVÁ, M. (ed.) Effective Decision Making: Analysis-Decision Making-Implementation and Evaluation (Efektivní rozhodování: Analyzování-Rozhodování-Implementace a hodnocení). 1. Edition. Brno: Edika, 2013. 393 s. ISBN 978-80-266-0179-1.

6 GRASEOVÁ-MOTYČKOVÁ, Monika and Jiři RICHTER, Methods of Strategic Analysis Used by Strategic Documents Processing in the Ministry of Defence - The Present and Possible Changes. Vojenské rozhledy - Czech Military Review. 2016, 25 (special issue), pp. 62-82. DOI: 10.3849/2336-2995.25.2016.05.061-081. ISSN 1210-3292 (print), 2336-2995 (on-line). Available at: www.vojenskerozhledy.cz

7 PROCHÁZKA, Josef. Report on Defence Research and Development Support Function, Analytical support to decision making in the area of defence and security, Case Study Canada and the Czech Republic. A study. Brno: Centrum bezpečnostních a vojensko strategických studií UO, 2016, 38 p. 


\section{Definition of the Analytical Support Function}

In general, the ASF might be defined as an operations research or operational research. It is a discipline that deals with the application of advanced analytical methods to help make better decisions. Employing techniques from other mathematical sciences, such as mathematical modelling, statistical analysis, and mathematical optimization, operations research arrives at optimal or near-optimal solutions to complex decision-making problems. Operations research is often concerned with determining the maximum (of profit, performance, or yield) or minimum (of loss, risk, or cost) of some real-world objective. Originating in military efforts before World War II, its techniques have grown to concern problems in a variety of industries. ${ }^{8}$

For the successful implementation of the ASF, it is critical to establish the right relation between practitioners and researchers. Both sides must make every effort to develop relationships that will enable practitioners to keep in touch with research developments and that will expose academics to the rapidly changing real world. Academics and practitioners should develop and support links that keep both parties up to date with important issues and enable them to develop jointly new knowledge and theory. Research is important, but there can never be any guarantee that any particular idea or project will be successful. Practice is important and the complicated world of deadlines and budgets will always make things difficult. ${ }^{9}$ Therefore, modern defence organizations maintain appropriate institutional framework for providing the academic level of expertise to assist practitioners in their effort to ensure effective and efficient defence.

The ASF in modern defence organisations is usually defined by: (1) stable institutional framework (organisation); (2) knowledgeable and experienced strategic and operational analysts and researchers (human resources); (3) institutional knowledge in the form of analytical tools and procedures (know-how); (5) processes allowing effective control and utilisation of this function including tasking, financing and evaluation (processes); and (6) appropriate support, such as IT, simulation, laboratories and others (material). ${ }^{10}$

The modern institutional framework for relevant ASF arrangement should address the following elements:

- Ownership including proper tasking and reporting arrangement;

- Appropriate business model, e.g. project management functional structure and processes;

- Motivated personal with required skills;

8 KATSALIAKI, K.; MUSTAFEE, N.; DWIVEDI, Y. K.; WILIAMS, T.; WILSON, J. M. (2010). A profile of OR research and practice published in the Journal of the Operational Research Society. Journal of the Operational Research Society. 61: 82. doi:10.1057/jors.2009.137

9 Williams, T., Wilson, J. \& Pidd, M. J Oper Res Soc (2005) 56: 479. doi: 10.1057/palgrave. jors.2601977

10 PROCHÁZKA, Josef. Report on Defence Research and Development Support Function, Analytical support to decision making in the area of defence and security, Case Study Canada and the Czech Republic. A study. Brno: Centrum bezpečnostních a vojensko strategických studií UO, 2016, 38 p. 
- Adequate financial resources while combining the institutional and customer ways of funding.

In a broader view, for the purpose of this study the ASF is understood as a complex activity portfolio embracing research and development (R\&D) on defence related phenomena and development of new processes, methods, tools, and equipment used for military purposes. The aim of these activities related to $R \& D$ is to deliver timely results and advice that advance the defence capability of the respective nation and its armed forces and strengthen the defence management.

In a much narrower context, the ASF comprises operational research and analysis (ORA), which focuses generally on conducting studies, analysis and information exchange activities that explore how operational capability can be provided and enhanced through the exploitation of new technologies, new forms of organization, or new concepts of operation. Such studies provide, where appropriate, explicit consideration of financial and other resource issues. In particular, the ORA focuses on the methods, techniques and procedures required to address the new issues brought up by the evolving strategic environment. ${ }^{11}$

\section{Research Methodology}

The research covers three defence research institutions providing a complex ASF to strategic defence management in Canada, Norway and Sweden and one agency responsible for providing the analytical support function for NATO.

The research concerns the following organisations:

- Defence Research and Development Canada (DRDC) ${ }^{\mathbf{1 2}}$

- Forvarets Forskningsinstitutt (FFI), Norway. English name: Norwegian Defence Research Establishment ${ }^{13}$

- Totalförsvarets Forskningsinstitut (FOI), Sweden. English name: Swedish Defence Research Agency (FOI) ${ }^{\mathbf{1 4}}$

- NATO Communication and Information Agency (NCIA), NATO15

The reason why these nations and institutions became the subject of this research was influenced by several factors. First of all, these institutions are recognised leaders of collaborative research of the System Analysis and Studies Panel (SAS Panel) of NATO Science and Technology Organisation (NATO STO). Secondly, they exercise stable defence policies accompanied with solid institutional frameworks including an in-house analytical function. Thirdly, these nations maintain high-quality armed forces whose size is comparable to the Czech Armed Forces (CZAF).

11 The System Analysis and Studies Panel Handbook Version 3.0, December 2014. p. 12.

12 Official DRDC website: http://www.drdc-rddc.gc.ca/en/index.page

13 Official FFI website: http://www.ffi.no/en/Sider/default.aspx

14 Official FOl website: https://www.foi.se/en.html

15 Official NCIA website: https://www.ncia.nato.int/Pages/homepage.aspx 
The research aims at answering the following questions:

a) Does the MoD have a formal institutional framework for research and development (R\&D) and operational research analysis (ORA)?

b) With whom does the highest authority for the R\&D management rest?

c) What is the legal statute, ownership and financing of the R\&D organisation(s)?

d) What is the mission of the R\&D organisation(s)?

e) What are the main research areas and what is the level of effort devoted to them?

f) What is the personnel strength of the R\&D organisation(s)?

g) What is the business model (modus operandi, tasking) of the R\&D organisation(s)?

For the assessment of main research focus of the R\&D organisation(s), two levels of

granularity were established: (1) Generic Focus Area (GFS), and (2) Specific Focus Area (SFA).

Generic Focus Areas embrace: (1) Strategic Level Decision Making, (2) Procurement,

(3) Operational Effectiveness, (4) Technology Development.

For each GFA, the following several SFAs were identified:

- Strategic Level Decision Making: (1) Defence Policy Development and Review, (2) Military Strategy Formulation, (3) Political Guidance Development, (4) Management of Force Structure Realignment and Readiness, (5) Strategic Resource Management, (6) Investment Portfolio Management, (7) Performance Measurement, (8) Property Management, (9) Human Resource Management, (10) Capability Planning.

- Procurement: (1) Bidding Process Preparation, (2) Bid Evaluation, (3) Life-Cycle Cost Analysis, (4) Cost-Benefit Analysis of Procurement Options.

- Operational Effectiveness: (1) Operations Assessment, (2) Lessons Learned from Operations, (3) Optimisation of Logistic Support, (4) Through Life-Cycle Maintenance, (5) Training, (6) Exercise Design and Evaluation, (7) Platform Availability, (8) Multiple Objective Optimization, (9) Fleet Replacement, (10) Different Platforms Trade-Offs.

- Technology Development: (1) Assessment of Technology Trends and Maturity for Military Exploitation, (2) General Engineering and Design.

- Additionally, Level of Effort (LoE) for each SFA was assessed against the following criteria: the number of analysts involved per year and the quality of decision influenced by the outcomes of the ASF. In both instances, this assessment was based on the professional judgement of employees (researchers) of the respective organisations. Also, in this case, the questions were included in the research survey.

- Levels of Effort:

- LoE 1 Very limited or almost no LoE - there is no significant LoE allocated to the SFA from the analytical support function (organisation).

- LoE 2 Low - there is a low LoE allocated to the SFA in terms of labour and time from the analytical support function (organisations). This LoE consists of variety of analytical inputs (expert discussions, analytical material as studies, reports and other analytical products). In quantitative terms, it is less than 1 analyst full time job per year equivalent.

- LoE 3 Moderate - there is a moderate LoE allocated to the SFA in terms of labour and time from the analytical support function (organisations). In quantitative 
terms, it is 1 analyst full time job per year equivalent. Additionally, this LoE is reflected in some way in the quality of the respective final outcome or the process of its development benefits from analytical inputs (analysis, studies, reports, other analytical products).

- LoE 4 Substantial - there is a substantial LoE allocated to the SFA in terms of labour and time from the analytical support function (organisations) and this effort is significantly reflected in the quality of the respective final outcome. In quantitative terms, it is more than 1 analyst full time job per year equivalent.

The answers to the research questions and the research focus and level of effort dedicated to the SFAs were sought using several methods. For Canada and Norway, staff talks were conducted in July 2016 and February 2017. Furthermore, the questionnaire for nations and organisations was developed and the research survey among the SAS Panel members conducted between October 2016 and May 2017. Responses were provided by Norway, Sweden, Turkey, and NCIA. Additionally, information for clarification and in some scope also for validation of data was searched at the Internet.

\section{Findings and Discussion}

The point of departure both for the Czech Republic and the analysed nations (Canada, Norway and Sweden) or organization (NATO) in the area of defence management is completely different. The Czech MoD has undergone fundamental structural changes after 1989 during a long transition process in order to establish a sound defence management system and modern armed forces according to the western standards. ${ }^{16}$

Nevertheless, even today this effort cannot be seen as a "mission accomplished". After several waves of sometimes questionable reforms, there is still the need for further optimization of the MoD's internal business process, enhancement of its overall performance and strengthening of the armed forces' posture and readiness. The critical functions in this regard include: (1) defence planning, (2) capability delivery with expected parameters, on-time and on-budget (armaments), and (3) sound human resource management.

The author of this article argues that one of the areas which could considerably reinforce the Czech MoD's overall performance and effectiveness in terms of forward looking planning, smarter resource management, providing better value for money in capability delivery, and last but not least contributing to successful operational deployments is the proper institutionalisation of the ASF. Relevant inspiration for this effort considers also the findings outlined in this article, which represent the best practices adopted by the analysed nations and their R\&D organisations. Moreover, the overall R\&D arrangement might be seen as a strategic enabler for the institutional adaptation and capa-

16 PROCHÁZKA, Josef. Adaptation of the Czech Republic Defence Policy - Lessons Learned. Security and Defence, 2015, vol. 6, no. 1, p. 15-28. ISSN 2300-8741. 
bility development. It is also an opportunity for knowledge transfer and multinational research and capability development. ${ }^{17}$

In the past, several attempts have already been made within the Czech MoD to institutionalize the ASF. Nevertheless, it has never succeeded to create a necessary institutional framework for its sustainable development in the long-term perspective. ${ }^{18}$

One of the preconditions for the successful ASF institutionalisation is the change of mindset and organisational culture at the Czech MoD, which will be supportive to more rigorous and evidence-based decision making. This kind of mindset and organisational culture would naturally create demand for rigorous analytical inputs into the decision making process, because unless there is a smart customer, there is no chance to establish a sound ASF according to the standards (best practices) implemented by the analysed countries.

Currently, technical defence research and development in the Czech Republic is ensured through state owned and to some extent also controlled defence R\&D enterprises (Military Technical Institute and Military Research Institute), state owned production enterprises (LOM Praha and VOP) providing maintenance and modernisation of most of the equipment operated by the CZAF. Furthermore, there are several organizations founded and sponsored by the MoD ensuring variety of services related to the medical support, including research, e.g. Military Hospital Prague, Institute of Aviation Medicine in Prague and Sport Research Institute of the CZAF (CASRI).

Additionally, there are several specialised institutions within the Czech MoD's organisational structure providing in-house defence research in the area of geography, hydrometeorology, medicine and military history. ${ }^{19}$

The research and development in the area of military science, military leadership, military technology, and military medicine is chiefly exercised by the University of Defence. The University of Defence is also part of the MoD's organisational structure and it might be considered - to some extent - as the "in-house ASF provider".

The responsibility for strategic analysis rests implicitly with the Centre for Security and Military Strategic Studies (CSMSS) of the University of Defence, unfortunately, with most of its capacity (almost $80 \%$ ) devoted to career education of high ranking officers (General Staff Course and Senior Officers Staff Course). ${ }^{\mathbf{2 0}}$

17 KOLín V. Česká republika a „nová“ Společná bezpečností a obranná politika EU: Čas zásadních rozhodnutí. Czech Military Review (Vojenské rozhledy). 2016. ISSN 1210-3292 (print), 2336-2995 (on-line). Available at: http://www.vojenskerozhledy.cz/kategorie/cr-a-nova-sbop-eu

18 Comprehensive analysis of the R\&D transformation between 1989-2009 is provided by JANOŠEC in his article Defence R\&D between 1989-2009 (Obranný výzkum a vývoj v letech 1989-2009). Military Review (Vojenské rozhledy) 2009/4. pp.71-82. ISSN 1210-3292 (print), 2336-2995 (online). Available at: http://www.vojenskerozhledy.cz/kategorie/obranny-vyzkum-a-vyvoj-v-letech-1989-2009

19 Concept on Defence Applicable Research, Development and Innovation 2016-2022 (Koncepce obranného aplikovaného výzkumu, vývoje a inovací na období 2016 až 2012). Ministry of Defence of the Czech Republic. Prague 2016. p. 9. Available at: https://vyzkum.army.cz/sites/vyzkum.army.cz/files/dokumenty/ zakladni-stranka/iii_koncepce.pdf

20 The calculations of CSMSS available capacities are conducted on regular basis as part of the routine management process and results are available at the executive management level of this organisation. 
The long-term tradition in the area of defence R\&D including the existence of expertise rested with the above mentioned $R \& D$ organisations are seen as the strength of the Czech MoD. On the contrary, the non-existence of institutional cooperation among the military and civil research institutions, limited centralisation of national capabilities in the defence $R \& D$ and insufficient research activities in the area of military strategy and operational art represent the weaknesses of the current institutional arrangement. ${ }^{21}$

In terms of focus of the defence R\&D, the priority focus areas of the Czech MoD follow the material rather than non-material research. Nevertheless, the general analytical support is also listed in that priority list. But it is reduced almost exclusively to conflict analysis and capability development for the purpose of security environment prediction. However, most of the focus areas of the ASF as it is understood and defined in this article are missing. ${ }^{22}$

Based on this assessment, it is possible to conclude that the ASF embracing operational research and analysis within the broader R\&D context is not formally institutionalized by the Czech MoD. Furthermore, there is no ambition to reinforce the existing "in-house" institutional arrangement in the mid-term time span. The objective is to utilize the existing capabilities of the Czech MoD's R\&D organisations and enhance the cooperation with civil research institutions rather than to develop a robust centralised R\&D organisation as an "in-house" ASF provider.

In the following paragraphs, the answer to the defined research questions and relevant findings will be communicated.

- Does the MoD have a formal institutional framework for research and development (R\&D) and operational research analysis (ORA)?

In comparison to the Czech Republic, nations such as Canada, Sweden and Norway have a long-term tradition of employing science in support of sound defence management. Despite limited resources, the political and military leaderships have always seen value added in the outcomes provided by an "in-house" maintained ASF.

An "in-house" ASF has been established during the World War II or shortly after. In case of Canada, for example, the main reason at that time was to optimize the protection of maritime convoys supporting the Canadian forces deployed on WWII battlefields. Since that time the variety of tasks fulfilled by the ASF has been significantly growing, embracing support to strategic planning, force development, force sustainment, and force deployment.

21 Concept on Defence Applicable Research, Development and Innovation 2016-2022 (Koncepce obranného aplikovaného výzkumu, vývoje a inovací na období 2016 až 2012). Ministry of Defence of the Czech Republic. Prague 2016. pp. 5-6. Available at: https://vyzkum.army.cz/sites/vyzkum.army.cz/files/ dokumenty/zakladni-stranka/iii_koncepce.pdf

22 Concept on Defence Applicable Research, Development and Innovation 2016-2022 (Koncepce obranného aplikovaného výzkumu, vývoje a inovací na období 2016 až 2012). Ministry of Defence of the Czech Republic. Prague 2016. pp. 7-8. Available at: https://vyzkum.army.cz/sites/vyzkum.army.cz/files/ dokumenty/zakladni-stranka/iii_koncepce.pdf 
Currently, the ASF is institutionalised by all three analysed nations and also NCIA. The ASF is provided by "in-house" R\&D organisations, in which organisational elements responsible for the provision of the ASF services are embedded. In the case of DRDC Canada, for example, the ASF is ensured by Centre for Operational Research and Analysis (CORA) with the strength of more than 100 analysts. In Norway, the ASF rests with the FFI's Defence Analysis Department. In terms of NCIA, the ASF is ensured by the Analytical Support Department responsible for the delivery of operational and planning support services. It comprises 26 analysts.

\section{- With whom does the highest authority for the R\&D management rest?}

In all three nations, there are high ranking MoD officials responsible for the defence R\&D management. In Canada, this responsibility rests with the Assistant Deputy Minister who reports both to the Deputy Minister of Defence and the Chief of the Defence Staff (CDS) of the Canadian Armed Forces (CAF). This arrangement makes the unique expertise resting with the R\&D function equally available to all customers both within MoD and CAF. In Sweden and Norway, this responsibility is assumed by the Division Directors. Within the NATO framework, the authority for the R\&D provision is exercised by the NATO Chief Scientist, who reports directly to the North Atlantic Council.

\section{- What is the mission of the R\&D organisation(s)?}

The top political and military leaderships of all analysed nations face a similar or even identical set of challenges in the pursuit of ensuring the country's defence as does the top-level management of the Czech MoD.

In general, the mission of the analysed R\&D organisations is to provide MoD, Armed Forces (AF) and other government departments as well as the public safety and national security communities with the knowledge and technologies needed to defend and protect national interests at home and abroad. These organisations should support the following processes: (1) formulation of relevant defence policy in the dynamic security environment, including the right set of strategic objectives, (2) establishment of equilibrium between those objectives and resources required for their successful implementation while taking on board acceptable levels of risks, (3) design of relevant, sustainable and still affordable force structure with appropriate levels of readiness to fulfil all assumed tasks, (4) identification of military requirements in short and long timeframe within the defence planning processes, (5) formulation and execution of the most suitable strategic portfolio - investment programs - with the highest value possible while considering broader political, operational, social, and economic interdependencies, (6) identification of the most effective human resource policy while competing on a constrained labour market, (7) last but not least, making decisions on operational deployments once it comes to the use of force for safeguarding the security interests of the country.

\section{- What is the legal statute, ownership and financing of the R\&D organisation(s)?}

All three nations run defence R\&D organisations as agencies. There is a transparent ownership mechanism in place to exercise the appropriate level of control through steering boards. The composition of these bodies ensures appropriate control mechanisms 
(transparency, effectiveness and efficiency). In the case of $\mathrm{NCIA}$, it is the Advisory and Steering Board (ASB), in which all NATO member states are represented.

There is variety of mechanisms to task these organisations based on different arrangements with customers. Basically, the tasking process with the principle customer (MoD and AF) reflects the discussion between agencies and their customers taking into consideration the customers' needs and financial possibilities and available capability and capacity of the respective agency. In case of Norway, the FFI offers also topics of potential interest to its customer. The agreed topics and costs are usually outlined in the program of work (PoW) and finally agreed by the steering board. Regarding DRDC, the tasking is reflected in research programs. Formulation of these programs and portfolio execution rest with several director generals dealing exclusively with the customers.

In terms of financing, the DRDC, FFI and FOI operating budgets are covered by the respective MoD's budget. The PoW is always customer funded. In case of FFI and FOI, the operating budget covers about $20 \%$ of the overall agency's needs. Interestingly, in all cases the funds from the MoD or NATO principal customers are re-allocated directly to the ASF provider without any formal competition (bidding) process. The agreed PoW serves as reference.

The NCIA's legal statute is defined in its charter. NCIA is a customer-funded organisation established by NATO. It is NATO's principal command, control and communication (C3) capability deliverer and communication and information service provider for the NATO HQ, the NATO Command Structure, NATO Agencies (including itself), nations and multinational organizations. ${ }^{23}$ Tasking of NCIA is the outcome of the customers' requirements identification against the catalogue comprising also approved rates (the decision making authority rests with the ASB).

- What are the main research areas and what is the level of effort devoted to them? Despite the technological development and material research exercised by all analysed national institutions (all invest substantial LoE in this area - see figure 2), there are basically two relatively broad areas of non-material research, in which the ASF services are delivered: (1) Analytical Support to Strategic Decision Making, and (2) Analytical Support to Defence Planning.

\section{Analytical Support to Strategic Decision Making}

DRDC and FFI allocate substantial LoE and FOI moderate LoE to the support of defence policy development and review. Furthermore, DRDC and FFI invest also substantial LoE to the support of military strategy formulation (see figure 2).

Defence policy development and review. Strategic analysts provide assessment of future security environment, including technology evolution, demography and economy. They assess impacts on the defence policy and strategy, role of the military power, mission of the military and capability development.

Close to real time strategic situational awareness - the management of force structure realignment and readiness. Analysts contribute to the development of management

23 Charter C-M 2012(0049) - 14 June, 2012. 
tools. ${ }^{24}$ They are objective, complex, administratively light and simple tools to be used for monitoring the strategic task implementation (performance management) and assessing force posture and readiness of all armed force elements in the horizon of up to 5 years.

Operational Effectiveness. Operational researchers support the optimal use of capabilities and resources for mission accomplishment of all services. These tasks embrace optimisation of logistic support, through life cycle maintenance, basic training, exercise design and evaluation, capabilities and capacity issues. Examples: optimization of platforms and their availability, pilot training and crew optimisation, surveillance and patrolling, multiple objective optimization, impact assessment of new operational deployments, fleet replacement and effect delivery of different platforms - trade-offs.

Contribution to SMART procurement. Operational researchers provide advice to help make sure that the given defence strategy is fulfilled in the most effective and efficient way - do the right thing right. In the area of procurement, they contribute to the life-cycle cost analysis and costing methods development, cost-benefit analysis of procurement options, bid formulation and evaluation.

Strategic Resource Management is a critical area for political and senior military leadership. Analysts address rapid change of political priorities in a constrained resource environment. The main tasks embrace the development of modern tools for investment (strategic) portfolio performance measurement, advanced visualization techniques for communicating value, risks and performance assessment for senior political and military leadership, corporate risk management, alignment of programs and individual projects with strategy and policy, and harmonisation of force generation process (Force Posture \& Readiness (FP\&R).

\section{Analytical Support to Defence Planning}

All analysed organisations allocate substantial LoE to the support of defence planning process, including trade-off analysis of different platforms (see figure 2).

Analysts assist in the development of sound and well-structured defence planning process while implementing the best practices from allies and partners.

The defence planning process is owned by the military, responsive to political expectations, addresses short and long-term timeframes, and mitigates uncertainty in the strategic environment, evolution in operating environment and resource constraints. The analysts' role is to provide assistance to the military, which encompasses planning process enhancement, environment assessment, scenario development, mission and capability assessment, requirement setting and validation, risk assessment and prioritisation of requirements.

24 The Strategic Managed Readiness Tool (SMaRT) has been used by the Canadian Armed Forces since April 2015. It provides the Chief of Defense Staff (CDS) with an efficient and effective means of articulating force generation tasks for the CAF and identifying risk of not being able to fulfil these tasks. It supports the Strategic Joint Staff in its effort to elaborate and implement the CDS Annual Directive on Force Posture and Readiness. 
$\mathrm{NCIA}$ uses a robust analytical instrument for defence planning (Joint Defence Planning Analysis and Requirements Toolset - JDARTS). It is an integrated federation of software applications developed to provide analytical support to the execution of the enhanced NATO Defence Planning Process (NDPP). JDARTS provides the Alliance with a unique and powerful analytical toolset, based on the consolidated military analysis of NATO staffs, in which coalition capability requirements can be systematically identified, stress tested and subsequently compared against the spectrum of military capabilities available to NATO in Steps 2 and 3 of the NDPP. ${ }^{25}$

FFI (NOR) adopted and customised JDARTS for their national needs via its membership in the Multinational Alliance Defence Analysis and Planning for Transformation (MN ADAPT) Smart Defence project. This project offers a cost effective means of training and supporting their national JDARTS evaluations and usage.

Support to Top-Down Planning. Meaningful and overarching political guidance and clear senior military direction is a critical component for the successful conduct of defence planning. The analytical support consists mainly of providing decision support to informing the development of strategic level documents and their elaboration subject to the defence planning guidance. Analysts help enhance the understanding of security environment trends and challenges, their implications for the future operating framework and roles of armed forces. They also support the identification of potential options in the endeavour to connect the means and the ways to the ends (objectives) of defence strategy.

Support to Force Generation Process (Force Posture and Readiness). The planning should address short term challenges in generating the right set of force elements and at the same time allow for long term thinking about the future requirements and create adequate time for force realignment if required. Analysts provide assistance in the process adaptation, guidance and directive formulation and force posture and readiness objective evaluation and associated risks assessment.

Support to Capability Based Planning. CBP is still a relevant tool for dealing with uncertainty and dynamics in the security environment. The use of scenarios supports the rigorous mission and capability analysis. The employment of analysts leads to the establishment of a sound methodological framework for CBP. Nevertheless, the military judgement is a critical component in capability assessment and requirement identification. It means that the CPB process is to be owned by the military!

Balancing Requirement and Resources. Analysts facilitate objective based prioritisation and risk assessment in a resource constrained environment. They assess (qualitatively) the relative value of each capability requirement for the mission accomplishment and operational risks associated with the non-existence of the capability for the mission accomplishment.

25 Staff talks between NCIA and CSMSS conducted in Brno and Hague in 2015. NCIA explained the JDART functionality and offered membership in the MN ADAPT Smart Defence project. Consequently, the outcomes of this discussion were presented to the leadership of Defence Policy and Strategy Department Division of the Czech MoD. 
Support to Bottom-Up Planning. Analysts support the enhancement of the existing strategic level lessons learned process and improvement of its conduct during exercises and deployments (preparation, collection and evaluation), including information and knowledge management (database, information sharing and access to lessons learned).

Support to Services. Analysts also assist services (Army, Navy, Air Force and Special Forces) in conducting their own planning activities spanning short, mid-term and long-term timeframes. In Canada, for instance, three levels of considerations are employed: Forces of Today (up to 5 years) -Tomorrow's Forces (from 5 to 15 years) - Future Forces (more than 15 years). The analytical support embraces the potential evolution of the future security environment and implications for the services' employment and capability development. The analytical tools are designed to serve this purpose, including the methodological and conceptual framework at services level. However, the approaches of various services differ. In Canada, services are fully independent and they use different processes and develop different outputs (documents). This effort helps the military leadership and officers understand the implications of alternative futures for their services in the complex manner along all the lines of capability development. In Norway and Sweden, the strategic level planning rests with the MoD and General Staff level. Services have only limited freedom to exercise their own capability development.

The ASF focus concern areas both generic and specific and the levels of effort devoted to each of them are assessed in matrix, which allows for a comprehensive comparison of all analysed organisations (see figure 2).

\section{- What is the personnel strength of the R\&D organisation(s)?}

FOI in Sweden employs 950 persons, 780 out of them are researchers and analysts.

The Norwegian FFI personnel strength is more than 700 people; more than 500 of them are researchers and analysts (50 of them dealing with the strategic analysis and operations research).

Canada exercises the most robust R\&D organisation. DRDC employs 1500 people, 800 of them researchers. The Centre for Operational Research and Analysis (CORA), part of DRDC, keeps more than 100 strategic analysts and operational researchers. ${ }^{26}$

\section{- What is the business model (modus operandi, tasking) of the R\&D organisati- on(s)?}

The importance of the ASF is reflected in the organisational structure of MoD. In all three nations, the ASF is an inherited part of the defence R\&D organisation within MoD. It is an in-house, centralised, robust, and high-quality capability able to satisfy the customer's needs with relevant multi-disciplinary expertise in a timely manner. Its valuable output outweighs the associated costs.

26 CORA consists of 5 sections (Strategic Analysis, Joint System Analysis, Maritime and Air, Land and Operational Command, Scientific and Technical Intelligence). Strategic analysts and operational researchers (mostly civilians) provide deep insight into problem solving. They develop unique expertise which is impossible to maintain within a system of rotating military personnel. In addition, they contribute to the institutional knowledge development (enhanced institutional memory). 
Integrated research and development function. In all three countries, the MoD entities providing R\&D services are integrated into one organisation (agency). Canada uses a distributed business model applying embedded personnel (analysts and scientists) throughout the MoD and AF organisational structure. It allows better cooperation with the customer, mutual trust and understanding development between analysts, civilian servants and military staff and an enhanced level of expertise sharing. Indeed, this organisational arrangement significantly contributes to better-quality product delivery as it is aligned with the customer needs.

Business model. The ASF has been adapted to the customer's needs on permanent basis. In Canada, the matrix of the internal organisational structure was introduced, emphasising the need for a close customer engagement while taking on board related coordination challenge with this model. It is basically built on two pillars. (1) Daily routine operations ensured by one overarching umbrella (CORA) and (2) responsibility for the program formulation and portfolio execution resting with several director generals dealing exclusively with the demand side (customers). It allows flexibility for the creation of inter-disciplinary teams designed to solve the respective problems with the required expertise in the most effective manner and at the same time with high level responsiveness to customer expectations. However, the matrix structure also requires enhanced coordination, an outcome oriented mind-set and team work cultural awareness.

The R\&D agencies in Norway and Sweden keep a traditional hierarchical structure usually dominant in the military environment.

The ASF embraces an in-house wide spectrum of scientific level expertise (from technical to social science, including technical intelligence). The emphasis is put on objectivity, scientific rigour and maintenance of freedom of action and strategic decision making. In addition, there is also an extensive multinational and bilateral cooperation and partnership with other scientific institutions and universities in order to deliver the missing elements of expertise, if needed. The international cooperation is essential for knowledge sharing and success. All three nations promote partnership and multilateral research within the NATO SAS Panel.

A critical aspect is also the protection of defence critical information, which support the in-house provision of the ASF.

Summary of this discussion and comparison of findings is provided in the matrix (see figure 1).

The strategic level findings demonstrate the environment and culture, in which the strategic defence management is conducted by all analysed nations:

- All three nations have been enjoying long-term political, social and economic stability, which is accompanied with solid institutional framework and sound processes. Changes in defence management and its support are subject to evolutionary adaptation rather than revolutionary turmoil. For example, Canada has adopted only six defence policy documents since WWII. ${ }^{27}$

27 The Czech Government adopted more than ten strategic level documents during the last two and half decades. 


\begin{tabular}{|c|c|c|c|c|}
\hline & FOI Sweden & FFI Norway & $\begin{array}{l}\text { DRDC/ } \\
\text { CORA Canada }\end{array}$ & $\mathrm{NClA}$ \\
\hline Responsibility & MoD Division Director & $\begin{array}{l}\text { MoD Division } \\
\text { Director }\end{array}$ & $\begin{array}{l}\text { Assistant Deputy } \\
\text { Minister of Defence }\end{array}$ & $\begin{array}{l}\text { NATO Chief } \\
\text { Scientist }\end{array}$ \\
\hline Mission & $\begin{array}{l}\text { Technical Research, } \\
\text { Defence Analysis and } \\
\text { Political Science }\end{array}$ & $\begin{array}{l}\text { Technical Research, } \\
\text { Applied Engineering, } \\
\text { Defence Analysis }\end{array}$ & $\begin{array}{l}\text { Technical Research, } \\
\text { Applied Engineering, } \\
\text { Defence Analysis }\end{array}$ & $\begin{array}{l}\text { Technical Re- } \\
\text { search, Applied } \\
\text { Engineering, } \\
\text { Defence Analysis } \\
\text { and Analytical } \\
\text { Support to NATO } \\
\text { Defence Planning }\end{array}$ \\
\hline Ownership & $\begin{array}{l}\text { MoD Agency, assign- } \\
\text { ment-based organisation }\end{array}$ & MoD Agency & MoD Agency & NATO Agency \\
\hline Financing & $\begin{array}{l}20 \% \text { Operating Budget, } \\
80 \% \text { Customer Funding, } \\
\text { PoW is covered by } 19 \% \\
\text { out of Government Grants }\end{array}$ & $\begin{array}{l}\text { Operating Budget/ } \\
\text { Customer Funded } \\
\text { PoW }\end{array}$ & $\begin{array}{l}\text { Operating Budget/ } \\
\text { Customer Funded } \\
\text { Research Portfolio }\end{array}$ & $\begin{array}{l}\text { Customer Funded } \\
\text { Mode (PoW) }\end{array}$ \\
\hline Employees & $950 / 780$ & $716 / 514$ & $1500 / 800$ & $26^{*}$ \\
\hline Business Model & $\begin{array}{l}\text { Centralised (researchers, } \\
\text { analysts and academics } \\
\text { concentrated in one } \\
\text { organisation) }\end{array}$ & $\begin{array}{l}\text { Centralised (re- } \\
\text { searchers and ana- } \\
\text { lysts concentrated in } \\
\text { one organisation) }\end{array}$ & $\begin{array}{l}\text { Centralised function } \\
\text { in several locations, } \\
\text { distributed perfor- } \\
\text { mance model (em- } \\
\text { bedded researchers) }\end{array}$ & $\begin{array}{l}\text { Centralised, in } \\
\text { several locations }\end{array}$ \\
\hline Tasking & $\begin{array}{l}\text { FOl suggests tasking to } \\
\text { customers (Armed Forces, } \\
\text { Swedish Defence Materiel } \\
\text { Administration, Swedish } \\
\text { Civil Contingencies } \\
\text { Agency). Decision made } \\
\text { by customers after } \\
\text { dialogue. The customers } \\
\text { provide the financing. } \\
\text { There are also customers } \\
\text { in the civilian sector, } \\
\text { including industry and } \\
\text { a range of public and local } \\
\text { authorities, primarily in } \\
\text { the fields of emergency } \\
\text { preparedness and securi- } \\
\text { ty, as well as from other } \\
\text { countries. }\end{array}$ & $\begin{array}{l}\text { PoW discussed with } \\
\text { customers (Armed } \\
\text { Forces and MoD). } \\
\text { Decision taken } \\
\text { by customer and } \\
\text { Steering Board. } \\
\text { Customers provide } \\
\text { financing. }\end{array}$ & $\begin{array}{l}\text { Responsibility for } \\
\text { program formulation } \\
\text { and portfolio execu- } \\
\text { tion rests with sever- } \\
\text { al director generals } \\
\text { dealing exclusively } \\
\text { with customers. }\end{array}$ & $\begin{array}{l}\text { PoW agreed } \\
\text { with customers } \\
\text { and approved by } \\
\text { Steering Board. }\end{array}$ \\
\hline Main Focus Areas & $\begin{array}{l}\text { C2, Information Technol- } \\
\text { ogy, Sensors, Materiel, } \\
\text { CBRN, Explosives, EW, } \\
\text { Security Policy, Defence } \\
\text { Analysis, Underwater } \\
\text { Research }\end{array}$ & $\begin{array}{l}\text { Electronic, Materiel, } \\
\text { CBRN, CD, IED, EW, } \\
\text { Defence Analysis }\end{array}$ & $\begin{array}{l}\text { Defence Analysis, En- } \\
\text { gineering, Economic } \\
\text { Intelligence }\end{array}$ & $\begin{array}{l}\text { Electronic, C3, } \\
\text { Defence Analysis }\end{array}$ \\
\hline
\end{tabular}

Figure 1: Analytical Support Function - Institutional Arrangement

* There are 26 analysts at the Analytical Support Department of NCIA, which might be augmented by contractors based on the current demand.

** Research for a safer and more secure future. FOI. Available at: https://www.foi.se/ download/18.38aa824f15a9fd6396e1282/1489138368046/FOI\%20i\%20fokus_ENG_print.pdf 
- All governments put significant level of emphasis on transparency and performance of public institutions, including military, and they seek the best value for money once it comes to public spending.

- There are several rather worrying trends with potentially negative impact on all countries and their armed forces' posture and readiness - aging critical equipment (submarines, fighter jets) and growing cost of military personnel. Recapitalisation of equipment and proper manning of structures is under risk taking into consideration the shrinking or stagnating defence budget.

- All nations' strategic culture calls for long-term forward looking. They allocate significant resources in terms of personnel, time and money to understand properly the evolution of future security and operating environment and its impact on the role of the armed forces and armed forces' development.

- The defence team (civilians and military within MoD and armed forces) sees the value added in the outcomes provided by the ASF; they are applied routinely in variety of areas (business process improvement, optimisation tasks in the area of logistic support, procurement decisions, risks assessment, assessment of operational effectiveness, performance measurement, forward looking planning support and many others).

- The ultimate benefit of the ASF for the decision makers is that it enables them to deconstruct and pinpoint a complex issue, better define risks and threats, work out technical solutions, and aid in the forecasting of the decisions' outcomes and impacts such that the leader is moving forward with a more complete picture. All three nations try to understand the impact of any strategic decision making.

- It is imperative to do the right thing right. While strategic analysis establishes the framework, in which our armed forces will operate in the future (defence policy objectives, ambitions etc.), operational research makes sure that the political and military leadership has the best advice available to conduct military missions in the most effective manner (trade-offs, optimisation of resources).

- As already mentioned, there is variety of findings stemming from this research, which can be considered as building blocks of best practices for the establishment of a solid institutional framework for the ASF and its focus.

\section{CONCLUSIONS}

After 1989, there were numerous serious problems related to the provision of defence in the Czech Republic, e.g. policy and strategy formulation in different phases of defence sector transition from the communist to the current era, realignment of force structure from mass armed forces to a much smaller professional force with expeditionary capabilities, and modernisation of obsolete capabilities, to name just a few of them.

One could argue that a substantial amount of tax payers' money could be saved and potentially even more suitable solution found, if tools such as the ASF were employed appropriately according to the standard code of conduct (best practices) implemented 


\begin{tabular}{|c|c|c|c|c|c|}
\hline \multicolumn{2}{|c|}{ Analytical Support Function - Focus and Level of Effort } & \multicolumn{4}{|c|}{ Organisations/Nations } \\
\hline $\begin{array}{l}\text { Generic Focus Areas } \\
\text { (GFAs) }\end{array}$ & $\begin{array}{l}\text { Specific Focus Areas } \\
\text { (SFAs) }\end{array}$ & FFI, NOR & FOI, SWE & $\mathrm{NClA}$ & DRDC, CAN \\
\hline \multirow{14}{*}{$\begin{array}{l}\text { Strategic Level } \\
\text { Decision Making }\end{array}$} & $\begin{array}{l}\text { Defence Policy Development } \\
\text { and Review }\end{array}$ & 4 & 3 & 2 & 4 \\
\hline & Military Strategy Formulation & 4 & 2 & 3 & 4 \\
\hline & Political Guidance Development & 2 & 2 & 2 & 3 \\
\hline & $\begin{array}{l}\text { Management of Force Structure } \\
\text { Realignment and Readiness }\end{array}$ & 2 & 2 & 4 & 3 \\
\hline & Strategic Resource Management & 4 & 3 & 2 & 3 \\
\hline & $\begin{array}{l}\text { Investment Portfolio } \\
\text { Management }\end{array}$ & 4 & 2 & 1 & 3 \\
\hline & Performance Measurement & 1 & 3 & 4 & 3 \\
\hline & Property Management & 1 & 1 & 1 & 2 \\
\hline & Human Resource Management & 4 & 3 & 1 & 3 \\
\hline & Capability Planning & 4 & 4 & 4 & 4 \\
\hline & Concept Development & 3 & 3 & 3 & 3 \\
\hline & Global Development & 4 & 4 & 3 & 4 \\
\hline & Information Operations & 1 & 2 & 1 & 1 \\
\hline & Civilian Defence & 1 & 4 & 1 & 2 \\
\hline \multirow{4}{*}{ Procurement } & Bidding Process Preparation & 4 & 1 & 1 & 3 \\
\hline & Bid Evaluation & 4 & 1 & 1 & 3 \\
\hline & Life-Cycle Cost Analysis & 3 & 2 & 2 & 3 \\
\hline & $\begin{array}{l}\text { Cost-Benefit Analysis } \\
\text { of Procurement Options }\end{array}$ & 4 & 3 & 2 & 4 \\
\hline \multirow{12}{*}{$\begin{array}{l}\text { Operational } \\
\text { Effectiveness }\end{array}$} & Intelligence Methodology & 1 & 3 & 1 & 2 \\
\hline & Operational Planning & 1 & 3 & 1 & 3 \\
\hline & Operations Assessment & 2 & 3 & 4 & 4 \\
\hline & $\begin{array}{l}\text { Lessons Learned from } \\
\text { Operations }\end{array}$ & 2 & 4 & 2 & 3 \\
\hline & Optimisation of Logistic Support & 3 & 3 & 3 & 3 \\
\hline & Through Life-Cycle Maintenance & 1 & 1 & 1 & 2 \\
\hline & Training & 4 & 2 & 3 & 4 \\
\hline & Exercise Design and Evaluation & 4 & 2 & 3 & 4 \\
\hline & Platform Availability & 3 & 2 & 1 & 4 \\
\hline & Multiple Objective Optimization & 2 & 2 & 2 & 4 \\
\hline & Fleet Replacement & 4 & 3 & 1 & 4 \\
\hline & Different Platforms - Trade-Offs & 4 & 4 & 4 & 4 \\
\hline \multirow{2}{*}{$\begin{array}{l}\text { Technology } \\
\text { Development }\end{array}$} & Technology Trends & 2 & 3 & 4 & 4 \\
\hline & Engineering & 4 & 4 & 4 & 4 \\
\hline
\end{tabular}

Figure 2: Analytical Support Function - Focus and Level of Effort 
by countries known for their modern defence sector management. Canada, Norway and Sweden and also NATO might definitely be considered among them.

This assessment is based on a proven list of records of implemented analytical projects, long-standing tradition of the ASF role in decision making and stability of institutions responsible for the ASF provision in these countries.

Since WWII, Canada, Norway and Sweden have developed strategic culture in the way that both political and military leaderships do not hesitate to refer to the analytical support once it comes to decision making in order to develop the broadest possible picture of the issue and understand the impact, consequences and associated risk the particular decision may pose. Informed and evidence-based decision making has become a critical element of strategic defence management and organisational culture of defence organisation in these three countries. Additionally, tax payers in these countries expect effectiveness, efficiency, accountability, and transparency of their public sectors.

Based on the assessment of the institutional arrangement of the R\&D function within the Czech MoD, it might be concluded that the transformation in this area has actually never finished. One of the reasons for it might be the continuous search for the most efficient institutional framework, balancing in-house capability and capability from the outside of the MoD's authority, both national and multinational.

Moreover, the potential of the ASF (as part of a wider R\&D function) has never been considered as significant for effective defence management in the Czech Republic. This approach was reflected also in an inadequate institutional framework, e.g. the authority for managing the R\&D function was delegated to the lowest possible level of responsibility within the MoD's organisational structure. Some of the in-house R\&D capabilities have been transformed into the form of state owned enterprises, some of them have been reorganised many times. There is a very niche capability in the field of the ORA resting with the University of Defence (CSMSS). One could argue that at the time of permanent institutional transition of the Czech MoD and AF and several periods of austerity there were no suitable conditions for developing a solid institutional framework for the ASF as defined in this article. As the outcome of these unfinished processes, the overall performance of the ASF was shrinking and some of its capabilities inevitably lost. ${ }^{28}$

Most likely, the Czech MoD will never be able to keep such a robust in-house ASF as Canada, Norway or Sweden, for instance. Nevertheless, the demand for an enhanced ASF should be considered again given the changing security environment and the growing importance of credible defence of the country. Based on the research outcome, emphasis should be put on the support to strategic decision making (defence policy and strategy formulation, procurement and resource optimization), long-term planning (long-term requirements setting and validation, performance measurement in terms of force posture and readiness, and strategic portfolio management - investments), and operations. There are areas in which all of the analysed institutions spend significant levels of effort.

The author argues that the Czech MoD should once again reinforce its in-house strategic analysis and operations research capability and establish a sound ASF based on the insti-

28 JANOŠEC, Josef. Defence Research and Development in Years 1989-2009. Military Review. 2009, 18(50), pp. 71-86. ISSN 1210-3292 (print), 2336-2995 (on-line). Available at: www.vojenskerozhledy.cz 
tutional arrangement in place in Canada, Norway, Sweden, and other countries. It is of utmost importance to draw on the experience and lessons learned of these nations, and where it is found useful, to utilize them to the greatest extent possible also in the Czech Republic. All three nations as well as NATO possess a viable institutional model for providing the ASF, which contributes to establishing best practices in the area of R\&D and ORA management among NATO allies and partners. The ambition of this article was to contribute to the future debate in this area, which should be opened soon rather than later.

Author: Josef Procházka, Ph.D., born in 1966. He is graduate of the Military Academy Brno. Later he served with the troops in the field of technological and automobile support, in staff positions at the General Staff and the Ministry of Defence and in the Institute for Strategic Studies in Brno. He completed his doctoral study in the programme Management of Defence of State. His military career was finished in 2007. Since 2011, he served as a defence advisor to the Czech Permanent Delegation to NATO. Currently, he acts as a director deputy of the Centre for Defence and Military Strategic Studies in Brno. He publishes in area of defence policy, sources management, defence planning, logistics and armaments.

How to cite:

PROCHÁZKA, Josef. Institutionalisation of the Analytical Support Function to Ensure Credibility of Defence Management - Canada, Norway, Sweden and NATO Case Study. Vojenské rozhledy. 2017, 26 (5), 3-22. DOI: 10.3849/23362995.26.2017.05.003-022. ISSN 1210-3292 (print), 2336-2995 (on-line). Available at: www.vojenskerozhledy.cz 
Peer-reviewed

\title{
The Internationalization of Conflicts: Theoretical Background, Conceptualization, and Contemporary Middle- East Region
}

\author{
Internacionalizace konfliktů: Teoretické pozadí, \\ konceptualizace a oblast současného Středního východu
}

Josef Kraus

Abstract: This article deals with the research of the internationalization of conflicts, trying to examine this phenomenon from the theoretical perspective and as a definition. Then the term of internationalization of conflict is conceptualized in order to be applied to a chosen internationalized internal armed conflict. The text also deals with various actors intervening in the internationalized conflict. They are divided into external and internal actors, while their interventions during civil war can be multilateral or unilateral. The concept of the conflict internationalization is also compared with the concept of the proxy war. The closeness of both terms can be confusing for many researchers and their division is one of the important outcomes of this article. At the end, two case studies of Syrian and Yemeni civil wars are introduced to the reader in the framework of the conflict internationalization concept.

Abstrakt: Tento text se zabývá výzkumem internacionalizace konfliktů, přičemž se snaží tento fenomén rozebrat po teoretické a definiční stránce, a následně jej konceptualizovat tak, aby bylo možné tento koncept využít pro výzkum vybraného konfliktu s mezinárodním přesahem. Text rovněž pracuje s různými druhy aktérů, kteří se do internacionalizovaného konfliktu zapojují. Rozlišuje především aktéry externí a interní, stejně jako intervence v konfliktu z jejich strany může být unilaterální či multilaterální. Uvedený koncept internacionalizace konfliktu je pak vymezen i vůči jinému blízkému konceptu tzv. zástupné války. Na závěr jsou uvedeny reálie dvou internacionalizovaných konfliktů na Středním východě - syrská a jemenská občanská válka.

Keywords: Armed Conflict; Internationalization; Proxy War; Conceptualization; State And Non-State Actors; Civil War.

Klíčová slova: Ozbrojený konflikt; internacionalizace; zástupná válka; konceptualizace; státní a nestátní aktéři; občanská válka. 


\section{INTRODUCTION}

The internationalization of conflicts has been a hot topic for the last couple of years. Many current civil wars have been internationalized due to foreign actors' interventions and many of those conflicts have been spread to (not only) a neighbouring country due to those interventions. A typical example of such a conflict is the currently ongoing civil war in Syria attracting not only local regional powers, such as Turkey, Saudi Arabia, and Iran, but also the global powers Russia and United States. The originally internal Syrian conflict has overflown into neighbouring Iraq and had a negative impact all other neighbouring states by the flood of war refugees. The intervention of the Gulf Cooperation Council armed forces led by Saudi Arabia into Yemeni civil war and Iranian support of Zaidiyyah Shi'as and chosen Yemeni tribes caused a huge disturbance in the Persian Gulf region and led to a situation called by some security experts a Saudi-Iranian proxy war. That is why the definition and conceptualization of the conflict internationalization are so important for current conflict researchers and security experts and analysts. The following text should create a background for resulting case studies of nowadays internal armed conflict not only in the region of Middle-East. The text itself has no ambition of bringing new scientific findings and extending knowledge, rather, it is a general survey of the examined phenomenon to be developed and researched in case studies by social sciences. At the beginning, there is a short introduction to related literature followed by the conceptualization of the chosen concept based on the most relevant sources. The emphasis is put on precise introduction to the terminology and conceptualization, that is why there are many exact quotations in the article. The main goal is to analyse available scientific literature and introduce it to the reader in the first part of the text, while the second part is a demonstration of the conflict internationalization concept based on a current hot conflict in the Middle-East. From this perspective, it seems redundant to the author to include any specific methodology, as the text has is more a survey rather than a scientific research.

\section{THE CONCEPT OF CONFLICT INTERNATIONALIZATION}

The concept of the conflict internationalization is not as wide-spread as many other concepts within security studies, thus, the spectrum of concepts, definitions, and terminology is rather limited. Nevertheless, there are some theoretical studies and many case studies dealing with the topic of an internal conflict spill-over, interference of external actors, proxy war, etc. There are also many perspectives on how to deal with this topic - those of political science, security studies, international law, or humanitarian. A connection between an ethnic conflict and its internationalization was created in the classic book by K. M. De Silva, Ronald James May in 1991 called "Internationalization of Ethnic 
Conflict"1 followed by a trio of authors David Carment, Patrick James and Zeynep Taydas in their book "Who Intervenes? Ethnic Conflict and Interstate Crisis" $\mathbf{2}$ and many of their common articles published subsequently. The ethnicity as one factor inclinable to the conflict internationalization is also reflected in the complex work of Kenneth Christie (ed.) $)^{3}$ called "Ethnic, Conflict, Tribal Politics: A Global Perspective". But ethnicity does not have to be the only factor of the internal conflict growing into the internationalized conflict. Amy Freedman 4 deals with a general internal conflict and its potential to become internationalized, and the edited book is one of the fundamental works on this topic explaining the internationalization of insurgencies, introducing concepts and theories, and focusing on chosen case studies about Iraq, Lebanon, Sierra Leone, and many others. With the concept of conflict internationalization, a typology of interfering actors is connected. A classic work in this field is the definition of the Uppsala Conflict Data Program. ${ }^{5}$ It divides actors according to the level of their involvement and way of their interference in an armed conflict. The main division is between primary and secondary parties. While primary parties are those directly involved in the conflict and having formed the incompatibility of warring parties' interests, secondary parties can be further divided into two types - warring and non-warring (internal or external). While a secondary warring party is one that enters a conflict with troops to support actively one of the sides in the conflict, a non-warring party (or secondary supporting party) provides support to a primary party, thus affecting the development of the conflict in a certain way. It is obvious that external actors in matters of the conflict internationalization can be both - primary and secondary parties, based on the way and level of engagement.

The internationalization can be easily defined as a process through which an explicit and conscious decision is made. The decision to involve international actors in any phase (hostilities or negotiation) of a domestic conflict. The alternative strategy or opposite way toward this action is to isolate the internal conflict and exclude any international actors, which is highly complicated in a globalized world with many interfering state and non-state actors. Sylvain Vité ${ }^{6}$ characterizes internationalization as an intervention by a third state in support of a non-governmental armed group opposed to state forces within an existing internal conflict. He points out that this fragmented application of international humanitarian law was implicitly favoured by the International Court of Justice in the case concerning military and paramilitary activities in and against Nicaragua: in its analysis of the conflict, the Court differentiated between, on the one hand, the conflict

1 De Silva, K. M. and May, R. J. 1991. Internationalization of Ethnic Conflict, Continuum International Publishing.

2 Carment, D., James, P. and Taydas, Z. 2006, Who Intervenes?: Ethnic Conflict and Interstate Crisis. Columbus: The Ohio State University Press.

3 Christie, K. 1998, Ethnic Conflict, Tribal Politics: A Global Perspective, Richmond: Curzon Press.

4 Freedman, A. (ed.) 2014, The Internationalization of Internal Conflicts-Threatening the State, London and New York: Routledge. ISBN13:978-0-415-50789-9

5 Uppsala Conflict Data Program, Definitions, available online at: http://www.pcr.uu.se/research/ucdp/ definitions/

6 Vité, S. 2009. Typology of armed conflicts in international humanitarian law: legal concepts and actual situations, International Review of the Red Cross, Volume 91 Number 873 March 2009. 
between the Nicaraguan government and the contras, and, on the other, the conflict between that same government and the government of the United States. From another perspective, Vité characterizes the internationalization of a conflict in the case that conflicts are not confined within the borders of a single state but concern two or more States.

Steward" brings a slightly different definition. According to him, the term "internationalized armed conflict" describes internal hostilities that are rendered international. The factual circumstances that can lead to internationalization are numerous and often complex: the term internationalized armed conflict includes war between two internal factions both of which are backed by different states, direct hostilities between two foreign states that militarily intervene in an internal armed conflict in support of opposing sides, and war involving a foreign intervention in support of an insurgent group fighting against an established government.

There is also a completely different point of view upon conflict internationalization. Not from the perspective of external interference, but from the perspective of movements of refugees and internally displaced people who escape abroad. It creates a threat to security of people in the countries that provide asylum. Albrecht Schnabel ${ }^{8}$ uses also other terms such as conflict spill-over or extension of the conflict. According to his research, the flow of forcibly displaced people influences the internal security of the receiving regions significantly. According to David Carmet, ${ }^{9}$ there are three existing theoretical approaches to the process of conflict internationalization: the theory of conflict extension, the theory of conflict interaction and human needs, and the theory of conflict transformation. The theory of conflict extension deals with the direct involvement of outside actors in the internal ethnic turmoil with a presupposed outside actor's self-interest in the conflict. This theory includes a factor of outside involvement, characterized by the extent to which the conflict is important to the international system. This argument presupposes a more extensive outside involvement in conflicts that are more important for influential outside actors. The theory of conflict interaction and human needs emphasizes internal ethnic conflict processes and describes the process of ethnic conflict internationalization through internal power seeking outside support. Leaders of various ethnic groups, fighting for power, call on the international community and supranational organizations, relying on human rights support, which lends a legitimacy to self-determination claims. The third theory, the conflict transformation theory is based on the assumption that conflict spill-over to the international level often occurs when a weak government cannot cope with internal ethnic, economic, social, and political problems. As a result, the governments look externally and make irredentist claims to the other

7 Steward, J. G. 2003, Towards a single definition of armed conflict in international humanitarian law: A critique of internationalized armed conflict, IRRC June 2003 Vol. 85 No 850.

8 Schnabel, A. 2002. Southeast European Security: Threats, Responses, Challenges, Nova Biomedical, ISBN: 978-1590330975, pp. 107-108

9 Carment, D. The Ethnic Dimension in World Politics: Theory, Policy and Early Warning, The World Quarterly, Vol. 15, No. 4, Winter 1994. 
states, in which respective minorities live. This strategy allows states to find an external scapegoat, project internal problems on it, and safeguard their own power and prestige.

However, for this article, we stay focused on the intervention of foreign actors into one state's business and then on an effect of one state's civil war on the neighbouring countries' internal security. There are two main types of internationalized internal armed conflict. First, one or more third states or international/regional organizations intervene in support of a state involved in an armed conflict against an organized armed group, or second, they intervene in support of an organized armed group involved in an armed conflict against a state. Also, the combination of these two types is possible. But the involvement of external actors can result in a different situation and phenomenon a proxy war. A proxy war can be defined as a war instigated by a major power which does not itself become involved or a conflict between two states or non-state actors when neither entity is directly engaged against the other.

\section{ACTORS OF CONFLICT INTERNATIONALIZATION}

From the actors' perspective, the decision to (or not to) internationalize can be made by both external and internal actors. In the first case, we can speak about regional hegemonic state or global power, in the second, local conflict parties, the state or non-state differentiation does not matter. According to Borda, ${ }^{10}$ the concept of internationalization moves along a continuum in which on one extreme, external actors such as powerful or neighbouring states, international organizations, and non-governmental organizations can decide to participate in a unilateral way. In this scenario, internationalization takes the form of interventions. On the other extreme of the continuum, parties to the conflict make this decision. They invite external actors at the same time (states, international organizations, NGOs, etc.) to participate in their own confrontation. In the same vein, on one extreme, international actors may decide not to take part or intervene in a certain internal conflict, and on the other, local parties can opt for blocking or avoiding international participation. For visualization, see the picture 1 below.

Why are local parties interested in attracting foreign actors to intervene in their domestic issues? Borda ${ }^{11}$ argues that parties to the conflict look for two fundamental assets when they internationalize their conflict: material resources to fight the war and international legitimacy. Material resources are usually connected to military support from abroad. Borda calls it military internationalization and characterizes it as the type of internationalization the parties to the conflict use in order to obtain external military or logistic support to fight the war and improve their military position vis-à-vis their

10 Borda, S. P. 2009. The Internationalization of Domestic Conflicts: A Comparative Study of Colombia, El Salvador and Guatemala, The Faculty of the Graduate School of the University of Minnesota, available at: https://goo.gl/ZHR8SX, p. 23

11 Ibid., p. 21 
opponents. For the second asset, according to Borda, parties to the conflict also attempt to gain legitimacy. The objective is to obtain political support for their cause: for the state, it means obtaining international approval for its right to govern and to fight threats against itself; for insurgent organizations, it means obtaining international support for their right to fight against what they consider an illegitimate state. Borda calls it political internationalization.

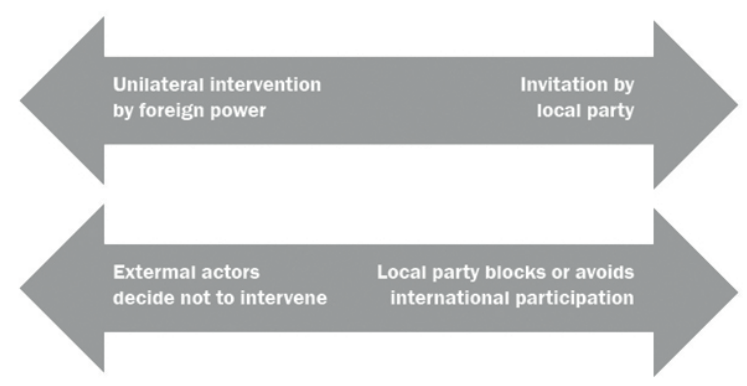

Figure 1: Axes of internationalization

Barnett and Levy ${ }^{\mathbf{1 2}}$ believe that weak state rulers seek international support or cooperation to deal with local security, political or economic problems. Economic and political constraints on the state's mobilization of societal resources are, according to the authors, a powerful incentive to make alignment concessions to others in return for military support to deal with external threats to security and for economic support to deal with threats to the domestic political economy. Hence, Third World leaders might prefer alliances over internal extraction because political leaders are often tempted to try to secure the material resources necessary to deal with (internal) threats (by placating disgruntled social groups or by other means) through external alliance formation rather than through internal extraction from a society that is already economically stretched and politically alienated. That is, Third World states often form external alliances as a means of confronting internal threats.

Gleditsch et. al. ${ }^{13}$ see two types of interests of governments engaged in civil wars in the initiation of military action against neighbouring states. First, these governments may undertake cross-border counterinsurgency actions because rebels often seek out foreign sanctuaries or attempt to flee repression by slipping across borders. The second type occurs when states experiencing civil wars engage in retaliatory attacks against interventionist neighbours in the hope of coercing them into withdrawing support.

12 Barnett M, Levy J. S. 1991. Domestic Sources of Alliances and Alignments: The Case of Egypt, 1962-1973. International Organization, Volume 45, Issue 3 July 1991, pp. 369-395

13 Gleditsch KS, Salehyan I, Schultz K. 2008. Fighting at Home, Fighting Abroad: How Civil Wars Lead to International Disputes. The Journal of Conflict Resolution, Vol. 52, No. 4 (Aug., 2008), pp. 479-506 


\section{CONFLICT INTERNATIONALIZATION AND CONTEMPORARY} MIDDLE-EAST REGION

As mentioned above, there are two main interstate conflicts in the region of the Middle-East ${ }^{14}$ - the civil war in Syria affecting neighbouring Iraq and the civil war in Yemen. The first example is much more complicated and illustrates better the concept of conflict internationalization, while the second one is considered a proxy war by many security experts.

In the Syrian civil war, it is possible to identify three levels of conflict from the actors' perspective and two levels considering the internationalization - a world powers' intervention, a local powers' intervention, and local parties' conflict. The interstate conflict is fought by primary actors such as the standard Syrian army and the regime of president Bashar Assad on one side, with many non-state actors such as Free Syrian Army, Al-Nusra Front, the so-called Islamic State and many rebel groups on the other, plus Kurdish militias fighting in defence of their nation. The situation is much clearer in neighbouring Iraq where the standard Iraqi army along with the Shia militias and Kurdish Peshmerga forces fight the Islamic State. Focusing on the internationalization and the two mentioned levels, it is possible to name two world powers interfering in the Syrian conflict - the USA and the Russian Federation.

The American position toward the Syrian war has gone through many stages, but currently it can be described as military presence on the field (mainly special forces helping Kurdish militias fighting the IS), air strikes against both state and non-state actors (targeting Assad's installations and forces, chosen rebel groups and the IS) and broad support of pro-US or anti-IS rebel groups by lethal and non-lethal material. Russians in Syria are even more active through their military presence on the field and air campaign, both targeting non-state actors - anti-Assad rebel groups. Russia actively supports president Assad and fights Russia's own rebels from northern Caucasus in many Syrian Islamic militias.

From the perspective of the local powers' intervention, Turkey, Iran and Saudi Arabia must be mentioned first. All three external actors are highly active and their interest is contradictory to each other. Turkey supports chosen Syrian rebels, but also actively stands out against both - state and non-state local parties of the conflict. One of its main motivation for intervening in Syria is the regional rivalry with Iran. Iranian loss of an important ally of Bashar Assad means Turkey's gain in the whole territory. That is why Iran interferes a lot in the Syrian business on the side of Assad. The religious aspect (Syrian ruling family is from the Alawite sect of Shia Islam) is also important for Iran. Not in its competition with Turkey, but in the rivalry with Saudi Arabia. The Saudi Kingdom is an official part of the air campaign against the IS, but at the same time, it supports rebels (and mainly Sunni extremists) against Assad's regime.

14 Of course, considering the wider region of the Middle-East, we can also mention the civil war in Libya, but it is a bit further from the focus of this article. 
There are also many other foreign actors intervening in the Syrian conflict such as some European states (mainly the United Kingdom and France) originally supporting rebels, now being part of the anti-IS coalition and air campaign against it, or external non-state actors such as Lebanese Hezbollah serving Iranian interests and supporting president Bashar Assad by its own military presence in the Syrian territory. ${ }^{15}$ There are also states such as Lebanon or Jordan that are affected by the Syrian civil war but do not interfere extensively in it. They are mainly in the position of states accepting refugees and Schnabel (mentioned above) emphasizes their risk of internal security threat caused by migrants from abroad.

In the case of Yemen, the situation of internationalization is much clearer. However, the Yemeni civil war in the perspective of its local parties is indeed chaotic. Reasons for the Yemeni conflict are based on tribal, religious and political issues and the intervention of Saudi Arabia and Iran escalated the conflict into something, which is by many experts called a proxy war between those two regional rivals. Saudi Arabia, as a leader of the intervening coalition of Gulf Cooperation Council military forces, supports Sunnis and chosen tribes (the question is whether they are or are not state or non-state actors), runs the air campaign and field military operations against rival tribes and "Shias" (Zaidiyyah, Houthis) and, of course, tries to suppress the Iranian influence in the area. Compared to it, Iran supports its co-religionists and chosen tribes and tries to resist the Saudi military effort in Yemen from a distance. In contrast to the Saudi Kingdom, Iran is not participating in the armed conflict directly, so Iranian and Saudi forces are not involved in direct clashes at the Yemeni territory. The proxy war seems quite a reasonable label for such a conflict, although Saudi Arabia is present on the battlefield.

\section{CONCLUSION}

Conflict internationalization as described and defined above is a highly up-to-date concept for researching nowadays conflicts worldwide. Chosen examples of Syrian a Yemeni civil wars are just a short demonstration of an internationalized conflict complexity. The conceptualization of the examined phenomenon and the typology of actors can be easily applied to any internal conflict with the interference of foreign states and parties. This text presents the main conceptualization and theories usable for further studies and researches and better understanding of conflict internationalization. Although the concept of conflict internationalization is still not reflected so much in the expert community and security analysis, it is still necessary to pay attention to it, especially in the present time full of undeclared wars, conflicts spilling over into neighbouring areas and confrontations of regional or world powers.

15 For more information see Kraus, J. Islámský stát: aktéři konfliktu, jejich participace, motivy a cíle, Vojenské rozhledy, 2015, roč. 24 (56), no. 2, pp. 20-36, ISSN 2336-2995, available at: http://www.vojenskerozhledy. cz/kategorie/islamsky-stat-akteri-konfliktu-jejich-participace-motivy-a-cile 
Author: Josef Kraus, Ph.D., born in 1985. He graduated from the bachelor's, master's and doctoral studies in political science at the Faculty of Social Studies, Masaryk University. He still acts as a scientific researcher there. At the same time he also acts at the Centre for Security and Military Strategic Studies of the University of Defence in Brno. He is also in the editorial circle of professional online magazine Rexter. He deals with the security problems of the Middle East region, with a focus on Islamic Republic of Iran and State terrorism research.

How to cite:

KRAUS, Josef. The Internationalization of Conflicts. Vojenské rozhledy. 2017, 26 (5), 23-32. DOI: 10.3849/2336-2995.26.2017.05.023-032. ISSN 12103292 (print), 2336-2995 (on-line). Available at: www.vojenskerozhledy.cz 
Peer-reviewed

\section{Military Scenario Development}

\section{Tvorba vojenských scénářů}

\section{Marius Titi Potirniche}

Abstract: Military scenario development is the subject of this article which is going to bring some essential characteristics and propose a working option for elaborating a scenario. The final aim is to help military planners have a good working procedure when developing a scenario in order to create a document updated with warfare evolution and operational planning process ready to respond to all risks and threats. The scenario is a way used by military structures at all levels of military art (strategical, operational and tactical) to get in contact with a probable unknown situation, to assimilate it and to sort it out. The article focuses on the scenario development process and proposes stages and activities that should be followed by a joint operational group when tasked with preparing a scenario.

Abstrakt: Tento článek věnovaný tvorbě vojenských scénářů představuje některé základní charakteristiky a praktické návrhy možností vypracování scénářů. Konečným záměrem je dát vojenským plánovačům $\mathrm{k}$ dispozici vhodný pracovní postup při vytváření scénáře s cílem vytvořit dokument s aktualizovanými informacemi o vývoji konfliktu a proces operačního plánování, který je připraven reagovat na všechna rizika a hrozby. Scénář je způsob používaný vojenskými strukturami na všech úrovních (strategické, operační a taktické) k umožnění kontaktu s pravděpodobnou neznámou situací, asimilace a vyřešení. Článek se zaměřuje na proces tvorby scénářů a překládá fáze a činnosti, které by měly společné operační skupiny pověřené přípravou scénáře dodržovat.

Keywords: Scenario; Military Training; Scenario Procedures; Planning; Methodology.

Klíčová slova: Scénář; vojenský výcvik; postupy scénářů; plánování; metodika. 


\section{INTRODUCTION TO SCENARIOS}

Scenarios are stories about how the future might look like. They are provocative and plausible stories about different ways in which relevant issues might evolve, such as missions, social unrest, weapon technologies, etc. Scenarios are neither predictions nor forecasts, they are designed to stretch thinking about the opportunities that the future might hold and to weigh possible threats carefully when making strategic decisions. The key focus of scenarios is uncertainty. Developing scenarios involves taking a wealth of information about the past and present, identifying patterns, and structuring coherent stories about the future. ${ }^{1}$ The term scenario is used to refer to the setting of frame conditions or the description of the system to be modelled. Scenarios lie somewhere in between predictions and speculations when the degree of uncertainty and complexity is of an intermediate level. ${ }^{2}$ In order to be effective, a scenario is recommended to be credible, real and easy understandable by the participants to show that the scenario is not about an abstract issue and it should be designed in a context linked to a real-life situation. They are designed to explore systematically, create and test possible or desirable future conditions.

Scenarios that look at future paths help decision makers manage risks and develop specific contingency plans. Describing how and why possible future situations might occur enables decision makers to reflect on how the structure, combat order and planning process can affect the operation and to plan accordingly. Scenarios are designed to bring up issues that otherwise would not be taken into account. They are most effective when dealing with big issues and strategic directions, rather than tactical decisions, and should not be used for short-term planning. ${ }^{3}$ It is acknowledged that a scenario is efficient if it is designed for a time frame of 4 to 6 years. Scenario analysis can help establish indicators that create a framework to monitor the execution of a strategy.

It is recommended to use scenarios when envisaging to clear up an unclear solution, or working in a highly uncertain environment, there is support for the scenario thinking process and any change that the results could bring is considered, and necessary resources for a full development and implementation are provided. It is recommended not to use scenarios when the problem is not central to the organizational strategy or the problem and solution are clear enough, the outcome is largely predetermined due to internal or external forces, the leadership wants to maintain the status quo, there is too much urgency to step back for a reflective and creative conversation and desired

1 Arden Brummell, Greg Mac Gillivray, "Introduction to scenarios", p. 2, http://www.scenarios2strategy. com/pdf/Introduction\%20to\%20Scenarios\%20and\%20Scenario\%20Planning.pdf Accessed on 06.04.2017. 
outcomes are poorly aligned with the dedicated resources. ${ }^{4}$ Scenario thinking requires looking beyond immediate demands and an open view far enough into the future to see new possibilities, asking "What if?".

\section{MILITARY SCENARIO TYPOLOGY}

For a long time, different specialists ${ }^{5}$ tried to categorize scenarios following some criteria, however, as the implementation environment changed, scenarios criteria or categories became irrelevant. As an example, there is a model proposed by Philip van Notten, ${ }^{6}$ who classified scenarios based on their scope (exploratory or for planning purpose), development design (intuitive or analytical), and content (simple or complex). There is another option to classify scenarios and I am referring especially to those from military field. The states generally periodically approve documents for military defence planning, referring to National Security Policy, White Book of Defence and Military Strategy. In fact, any military strategy contains references to the possible risks and threats, national military objectives, military capabilities and priorities to fulfil them, details about military structures, directions on how to configure, dimension, train and equip the army, and it sets up operational concepts to fulfil the objectives and missions of the army. ${ }^{7}$ The White Book of Defence sets up specific missions for the army as well as the main capability development directions. Scenarios could reflect the following situations, which are not prescriptive or future proofed, generally referring to emerging or existing crisis, time-sensitive crisis, technological incidents, man-made or natural disasters, asymmetric threats, such as those arising from terrorism, proliferation of weapons of mass destruction, and use of chemical, biological, radiological and nuclear, and cyber attacks.

These elements form the basis for the development of a scenario categorized as a strategic scenario. The probable strategic scenario can take into consideration conventional military actions, special operations, operations other than war, humanitarian aid, etc. Starting from some phases of these strategic scenarios, with minor amendments, we can create the exercise scenarios, the second category. Scenarios from this category can be divided into real scenarios (for instance, when there is an intention to analyse a certain war mission and real forces and equipment are involved in a real simulation) or fictional ones (for instance, when a military action is envisaged to test a certain military capability). It is to be avoided, at least for the military field, to speak about simple or complex scenarios. Scenario has to contain all the necessary elements to fulfil the mis-

4 Diana Scearce, Katherine Fulton, "What If? The Art of Scenario Thinking for Nonprofits", p. 21, GBN Global Business Network, 2004.

5 Ducot și Luben (1980), Duncan și Wack (1994), Postma (1995), Godet și Roubelat (1996), Heugens și Van Oosterhout (2001).

6 Philip van Notten, "Scenario development: a typology of approaches", Think Scenarios, Rethink Education, 2006.

7 Defence Romanian Planning Law, 2013/2015. 
sion and training to defend the state and it is not at all simple. Moreover, it is complex, and as long as there are certain operational procedures, these must be followed, while is hard to identify the border between simple and complex.

\section{SCENARIO DEVELOPMENT PROCESS}

The way of developing a scenario involves many innovative suggestions and the variety in phase development and the structure of it depends on the training audience, objectives and the rank of the organizations. The scenario process of projection and making up is very laborious and requires extensive human, logistic and informational resources. If the scenarios are made up in a complete and efficient manner, the activities generated by the scenario proceedings fulfil the objectives established. The specialists in the area of scenario development created different models and algorithms for scenario generation. These contain a series of activities, recommended to be followed, in order to have a guarantee that in the end a good and high-quality scenario is obtained.

The stages that many planners take into account, with some variations, are proposed as follows:

- Clarifying the focus of the scenarios - The centre of gravity of the entire process of scenario development is to define the framework of the scenario and it is made up of two stages: (1) defining the framework of the scenario from the informational viewpoint; (2) defining the framework of the scenario from the conceptual viewpoint. During the first stage, the operational environment, the crisis situation and the threats must be evaluated and analysed. The second stage introduces the need to analyse the strategic relationship between the actors involved, thinking and selection of the way in which to develop the scenario.

- Working group set up - It is important to set a heterogeneous working group, with a good level of competence and different military background to cover all informational environments necessary for a comprehensive approach to the scenario. ${ }^{8}$ The main activities of the working group are directed in two ways: (1) planning, organising and coordination of the activities, meeting mediation, assistance to follow the procedures for scenario development, writing reports and informing the participants about the intermediary results; (2) recording, centralised processing, intermediary result evaluation and preparing the final scenario documents. This working group can be made up from a script writer nucleus, expert group, consultant group and support group. The scenario working groups must face challenging and surprising events in the process of elaboration, because they have in mind the issues that are very familiar to them, meaning their own field of expertise or military profile they belong to. On the other hand, thinking out of the box begins with a revision of external changes that might, over time, profoundly affect the mission

8 I. BALACEANU, L. DUTESCU, I. MARTIN, "Scenario projection and military action simulation", Manual, UNAp “Carol I", 2007, p. 40. 
or the structure of the unit, a seemingly irrelevant technological development that could prove advantageous for service delivery, for example, or a geopolitical shift that could introduce unforeseen weapon development.

- Documentation - It is important to read a vast amount of literature and documents describing the possible future security environment and wider geopolitical context. The literature review involved is a way to identify those trends which would have potential implications for the nature of future conflicts. The literature review also considers the types of actors (such as states, non-state actors, private security and defence contractors, etc.) that might be expected to be active in the future security environment.

- Setting up basic scenario elements - These elements are regarded both for the conceptual aspect of the scenario and the operational issues. The conceptual aspect directs the process of scenario development and considers the issues, aim, objectives and type of scenario, techniques and procedures to be followed during the development process, dynamic activities and working group responsibilities and attributions. The operational aspects imply information concerning the time frame of the scenario, area of operations, missions, constraints and restraints from political, legal and military point of view, the framework established, new actors involved and their doctrinal concepts. ${ }^{9}$

- The general framework - The goal of this phase is to clarify the issue at stake and to use these issue as an orienting device throughout the scenario. ${ }^{10}$ It should include a generic description of the crisis area, the major regional actors and the historical background of the situation, in which, later on, exercises will be executed. It contains a regional situation based on a set of country books including information on the history, people, government, economy, geography, communications, transportation, and, in particular, security and transnational issues. It should be regularly reviewed to ensure that it is aligned with the strategic interest of the planners. Where applicable, it should be developed with a view to support exercises over a time frame of several years and with due caution to political sensitivities and should cover, in particular, the following aspects (this list is neither prescriptive nor exhaustive): political and security situation; rule of law; humanitarian activities; state building; reconstruction and development aid activities; presence and activities of the international community; natural resources and environmental issues; support to civil authorities.

- Storylines are specific for scenarios and include detailed information on circumstances and events that lead to a specific crisis situation at the beginning. They synthesize and combine the driving forces that have been identified when creating the scenario. This is a narrowing phase and it is composed of the following elements: development of the situation, which is a narrative chronological summary of the main events leading to the beginning of the scenario; list of events, a tool for

9 Dan Lucian PETRESCU, "Research Report nr. 1", Editura UNAp “Carol I", 2015, p. 91.

10 Elizabeth Collins, "Scenario Thinking", on Prezi https://prezi.com/kyzemrdhoe11/strategicplanning/?utm_source=twitter\&utm_medium=landing Accessed on 18 March 2017. 
the team conducting the exercise to control it, that constitutes the detailed script of the exercise play and includes the complete set of events (major occurrences or a sequence of related incidents developed to support the achievement of the exercise objectives), incidents (actions or situations that provide greater clarity to an event), and injections (the way of bringing an incident to the attention of the training audience for which it was created to be made using communication means and, where available, media formats). Each main event will have one or more incidents that are presented to the training audience by means of injections. In the process of developing events, a few questions should stay up front: If this scenario represents the future, what actions should we take today to prepare? Are there actions we could take to catalyse a desirable future or to mitigate a negative one? The answers to these questions are the scenario implications. Are any of the implications valid in all scenarios? The issue covered by these elements as well as its contents depend on the complexity of the scenario and the level of details required.

- The enabling and supporting documents are developed in line with the general framework and storylines to inform the conduct of the future exercise. The format and content of these documents should be prepared in order to imitate the operating environment as realistically as possible. These in themselves provide an excellent opportunity for in-house training and familiarization. They can include, inter alia: UNSC resolutions and/or other documents providing legal basis for the action; letters exchanged between the United Nations, EU, NATO and national or regional authorities; council decisions related to the scenario; political framework for crisis approach; crisis management concept; civilian and military strategic options; initiating military directive; civilian and military advice; intelligence reports or risk assessment; fact finding and exploratory mission reports; humanitarian reports; status of force and status of mission agreements (SOFA/SOMA); memorandum of understanding (MOU); technical agreements related to the scenario and force structure results.

- The geo-data is developed to illustrate the scenario in the format of maps and database. It should contain the static information/data about the region needed to support the conduct of the scenario. It may consist of whole or various mixes of real, synthetic and fictitious information/data. Information and data will be produced according to information standards and support the use of appropriate services and agencies that you work with. Costs associated with the production of geospatial information for the exercise scenarios as well as the production time impacts have to be taken into account from the very beginning of the exercise planning.

- Evaluation - It is a phase in which the working group makes sure that the scenario is aligned with the logistic and operational requirements based on the criteria established in previous phases. The established criteria should make sure that the scenario is realistic, objective, robust, complete, coherent, and feasible. In or- 
der to help the training audience better understand the requirements, scenarios are checked for format, graphics, drawings, maps, and writing. ${ }^{11}$

\section{CONCLUSIONS AND RECOMMENDATIONS}

Long term planning is a basic requirement for a modern and efficient military strategy. Using military scenarios as a contextual support for plan development brings a significant value of efficiency and viability alongside the possibility to attain good estimation to the question "What If?". The main aim is to identify and to apply all the necessary measures to maintain, for a long period of time, the correspondence between the characteristic of the military organisation and the actual and future operational environment. In order to succeed in such a challenging endeavor as a scenario development, it is necessary to assess carefully and decide whether there are sufficient time, resources and type of forces that are to be trained according to the most challenging potential evaluated risk. Initiators should make sure that the overall aims of the scenario and a large variety of the forces are involved, not only in the scenario maintenance, but also the forces to be trained. The establishment of confidence between the outside participants through transparency and open-discussions in order to have them deeply involved in supporting the scenario is another important task that must be solved. From the outset, testing priorities and limits of the scenario must be well set up and it must be ensured that the participants understand how the scenario would progress, as early as possible. By using all the available means to share and disseminate the inputs and results of the scenario, the development team can get the guarantee of a successful mission accomplishment.

Author: Mr. Marius Titi POTIRNICHE, Ph.D., is a researcher at the Center for Defence and Security Strategic Studies at the "Carol I" National Defence University, Bucharest and a retired colonel of the Romanian Armed Forces. His main interests are related to military doctrine and theory, military strategy and their impact on armed forces development.

How to cite:

POTIRNICHE, Marius Titi. Military Scenario Development. Vojenské rozhledy. 2017, 26 (5), 33-40. DOI: 10.3849/2336-2995.26.2017.05.033-040. ISSN 12103292 (print), 2336-2995 (on-line). Available at: www.vojenskerozhledy.cz

11 Dan Lucian PETRESCU, “Research Report nr. 2", Editura UNAp “Carol I", 2016, p. 57. 
Peer-reviewed

\title{
Czech Defence Policy - Critical Assessment and Recommendations
}

\section{Česká obranná politika - kritické hodnocení a doporučení}

\author{
Josef Procházka, Lukáš Dyčka
}

Abstract: The research described in this paper was conducted in the framework of institutional research project Strategic Alternatives (STRATAL) within the Centre for Security and Military Strategic Studies of University of Defence in Brno, the Czech Republic. The main objective of this contribution is to assess the evolution of the Czech defence policy (CDP) since the last summer 2016. The authors analysed the key change drivers (KCDs) and measures taken in political, military, administrative, economical and societal domain in order to evaluate the overall effectiveness of the defence policy. Finally, the authors offer several recommendations to enhance the responsiveness and preparedness of the Czech defence system and the Armed Forces both in short- and longterm time span.

Abstrakt: Výzkum popsaný $v$ tomto dokumentu se uskutečnil v rámci výzkumného projektu Strategické alternativy (STRATAL) v rámci Centra bezpečnostních a vojenskostrategických studií Univerzity obrany v Brně, v České republice. Hlavním cílem tohoto př́spěvku je zhodnotit vývoj české obranné politiky od léta 2016. Autoři analyzovali klíčové hnací síly změn a opatření prováděná v politické, vojenské, správní, ekonomické a společenské oblasti s cílem vyhodnotit celkovou účinnost obranné politiky. Na závěr autoři nabízejí několik doporučení s cílem zvýšit reakceschopnost a připravenost českého obranného systému a ozbrojených sil $v$ krátkodobém i dlouhodobém časovém horizontu.

Keywords: Defence Policy; Key Change Drivers; Armed Forces; Defence System; Security Strategy; Defence Strategy; Strategic Environment; Security Environment.

Klíčová slova: Obranná politika; klíčové hnací síly změn; ozbrojené síly; obranný systém; bezpečnostní strategie; obranná strategie; strategické prostředí; bezpečnostní prostředí. 


\section{INTRODUCTION}

The authors of the paper argue that the current process of adaptation of the Czech Republic's defence policy is heavily shaped by numerous external as well as internal aspects, however, their implications are not always addressed adequately. This will be the main focus of this article.

From the external point of view, both continuous trends and new impetus must be taken into account. External continuous trends include mainly the threat of assertive Russia, migration from North Africa and Middle East, terrorism and cyber-related threats with other implications such as hybrid, asymmetric and information warfare. All of these were underlined in various strategic documents of the Czech Republic, e.g. most recently in the updated version of our Defence Strategy $2017^{1}$ and previously in Security Strategy 2015. These trends and their impact were assessed in the last year's version of this study ${ }^{2}$ and remained unchanged in their pattern. According to the authors' assessment, new impetuses 2016/2017 can be summed up in three areas: (1) Brexit - challenging the EU integration; (2) US president Trump - mounting pressure on European allies to provide fair collective defence contributions ( $2 \%$ of GDP benchmark as a precondition for article 5 guaranties); (3) Turkey - currently playing the role of Trojan horse within NATO.

Internal factors for the purpose of this article are assessed in following domains: (1) political; (2) military; (3) administrative; (4) economic, and (5) societal.

Furthermore, the authors' ambition is to offer their view on the way ahead in those areas in order to promote discussion on the future course of action in the evolution of the Czech defence policy. Conceptually, this text is put in the context of long term adaptation of the Czech defence policy after 1989 and methodologically it follows the logic of the defence policy assessment from the last year. ${ }^{3}$

1 Defence Strategy of the Czech Republic 2017. The Ministry of Defence of the Czech Republic - MHI Prague, 2017. ISBN 978-80-7278-702-9 Available at: http://www.army.cz/images/id_8001_9000/8503/ DefenceStrategy2017.pdf

2 PROCHÁZKA, Josef and Lukáš DYČKA, Jakub LANDOVSKÝ, Reakce české obranné politiky na dynamiku vývoje bezpečnostního prostředí. Vojenské rozhledy - Czech Military Review, 2016, 25 (special issue), pp. 3-17. DOI: 10.3849/2336-2995.25.2016.05.003-017. ISSN 1210-3292 (print), 2336-2995 (online). Available at: www.vojenskerozhledy.cz

3 PROCHÁZKA, Josef, DYČKA, Lukáš, LANDOVSKÝ, Jakub. Proces získávání poznatků a využívání zkušeností jako součást procesního řizení v resortu Ministerstva obrany. Vojenské rozhledy - Czech Military Review, 2016, 25 (Mimořádné číslo), pp 3-17. DOI: 10.3849/2336-2995.25.2016.05.003-017. ISSN 1210-3292 (print), 2336-2995 (on-line). Available at: www.vojenskerozhledy.cz 


\section{EXTERNAL INFLUENCES}

The last year (2016/2017) has been dominated by the aforementioned external influences, out of which (in chronological order) Brexit represents the first significant issue to be dealt with. One of the immediate responses of the Czech Republic to Britain leaving the European Union, echoed even by the Western media, was the call from certain members the of political elite for the creation of an EU army. ${ }^{4}$ This included president Miloš Zeman and the then prime minister Sobotka, who stated that "only EU-wide armed forces will allow us to defend our interests on our own". ${ }^{5}$ According to the original idea voiced by the Czech prime minister during the summer 2016, the European Army was supposed to be used mainly for the defence of the EU borders against migrants and as a sign of European military emancipation (with regard to the USA). While not generally accepted, the idea of the Common EU Army spurred a considerable debate. It was, however, quickly rejected by the Minister of Defence ${ }^{6}$ with the main argument being that even the embryonic phase of building an EU army - the EU battlegroups - is hardly considered a successful project, thus, any further integration is premature and it would only weaken NATO. More recently, "Common EU Security Forces" replaced the name "Common EU Army" in political rhetoric.

Nevertheless, Brexit is creating space for strengthening the military cooperation among the remaining EU member states. The need to step up defence cooperation is echoed not only form France and Germany, but also from many other capitals. Because of structural changes in both the strategic environment (demand) and the economics of defence (supply), when it comes to technology, procurement, and weapon manufacturing, there is a strong case for European countries to move beyond their traditional approach to defence cooperation. ${ }^{7}$ Framework for this enhanced cooperation provided by the EU Global Strategy (EUGS) published in June $2016^{8}$ creates room for subsequent initiatives. Along with the Military Planning and Conduct Capability (MPCC), the European Defence Fund, the prospect of Permanent Structured Cooperation (PeSCo) and the so called coordinated annual review on defence (CARD) emerge at a time when member states are seeking to build on the momentum of European defence. Especially the work on CARD should be undertaken in coherence with the implementation of the European

4 Hamáček, Jan. 2017. Proč potřebujeme evropskou armádu. Available at: https://www.cssd.cz/aktualne/ blogy/proc-potrebujeme-evropskou-armadu/

5 Ghez, J, Kirchner, M., Shurkin, M., Knack, A., Hall A., Black. J., 2017. Defence and security after Brexit: A snapshot of international perspectives on the implications of the UK's decision to leave the EU. Santa Monica, CA: RAND Corporation, Available at: https://www.rand.org/pubs/perspectives/PE225.html.

6 Novotná, K., 2016. Evropská armáda je utopie a plýtvání penězi, kritizují politici Sobotku. Available at: http://echo24.cz/a/iubn7/evropska-armada-je-utopie-a-plytvani-penezi-kritizuji-politici-sobotku

7 Gilli A. Gilli, M. 2017. European defence cooperation in the second machine age. Available at: http://www. iss.europa.eu/de/publikationen/detail/article/european-defence-cooperation-in-the-second-machine-age/

8 Global Strategy for the European Union's Foreign and Security Policy. 2017. Available at: http://eeas. europa.eu/archives/docs/top_stories/pdf/eugs_review_web.pdf 
Defence Action Plan. Common feature of all of these initiatives within the EUGS framework is the stress on the gradual synchronisation and mutual adaptation of national defence planning cycles and capability development practices. ${ }^{9}$

While the Common Security and Defence Policy of the EU may (in some regards) be strengthened by Brexit, NATO has been much more influenced by the accession of the newly elected US president Donald Trump. The security guarantee provided by NATO and the US forms the cornerstone of security policy for the EU member states, especially in Eastern Europe, which applies to the Czech Republic as well. However, president Trump's push for "America First" policies awkwardly coincides with a build-up of NATO troops in Eastern Europe. In 2016, NATO re-established deterrence of Russia as one of the main priorities of the alliance and approved the deployment of four multinational battalions in Poland and the Baltic states. In May 2016, the US officially activated a land-based missile shield system in southern Romania. In January 2017, the first contingent of US troops arrived in Poland. Moreover, the US already has several hundred soldiers in each Baltic state, including the US special operations troops.

What is more pressing, though, is Trump's desire to end the perceived free-riding on US security guarantees and to encourage other NATO members to increase military spending..$^{10}$ However, this is not a fundamental change in the US foreign policy. The Obama administration had taken a similar approach. Many EU countries have been increasing defence expenditure since 2014 in response to the rising concerns about Russia following its annexation of Crimea, but the confrontational tone of the Trump administration may accelerate these countries' efforts to reach the NATO's $2 \%$ of GDP target for military spending. The Baltic states have committed to increase their military spending to at least $2 \%$ of GDP (Estonia is already there) and others, including the Czech Republic, but also France, Germany and Romania were already increasing their military spending even before Trump's election - but certainly not up to $2 \%$ of GDP.

After his visit in the US and meeting with the US Secretary of Defence Mattis in early May 2017, Czech minister of Defence announced that reaching 2\% of GDP is likely in $2025 .{ }^{11}$ This step is widely seen as a reaction to the substantial pressure from the US president. However, similar promises were made repeatedly in the past.

The last year's list of important external factors influencing the Czech defence policy (at least in an indirect way) would not be complete without including the gradually changing status of Turkey. In regard to its defence policy, this move away from the NATO values started long time ago and it is tied to president Erdogan's domestic political ambitions

9 The CARD on the EU defence table by Daniel Fiott European Union Institute for Security Studies (EUISS) April 20172

10 The Economist. 2017. Available at: https://country.eiu.com/article.aspx?articleid=1715169755\&Country=Czech\%20Republic\&topic=Politics_2

11 Ministr Stropnický: Vrtulníky české armádě dodají USA nebo Itálie. 2017. Lidovky.cz. Available at: http:// www.lidovky.cz/ministr-stropnicky-vrtulniky-ceske-armade-dodaji-usa-nebo-italie-p9d-/zpravy-svet. aspx?c=A170502_224422_In_zahranici_ELE 
escalating into the Turkish constitutional referendum in April 2017. Not only did it abolish the existing parliamentary system of government and replaced it with a presidential one, but violent pre-referendum campaign among members of the Turkish minority abroad damaged the relationship with some NATO countries. ${ }^{12}$ Relations with the Netherlands are all but broken off, Germany is so far struggling to remain civil under a barrage of Erdogan's insults, and Denmark is siding with its north European neighbours. Furthermore, according to the proposed amendments to the Turkish constitution, individuals with relations to the military would be ineligible to run for election, which is another move away from the Turkish defence posture in the last century. These changes in many ways qualify the Turkish political system as non-democratic. ${ }^{13}$ Turkey is in some respect already violating the statement in the Preamble of the North Atlantic Treaty, that the alliance is "determined to safeguard the freedom, common heritage and civilization of their people founded on the principles of democracy, individual liberty and the rule of law". Add to this Turkey's differences with the US and the perennial tension between Turkey and Greece, and it is no longer clear how much of a NATO member Erdogan's country really is. Despite its considerable military strength, Turkey's participation in alliance activities is not extensive, and its interests do not necessarily align with those of NATO". ${ }^{14}$

As far as the Czech Republic is concerned, the greatest impact of current turmoil in Turkey on our defence policy came in the aftermath of the failed coup d'état attempt in July 2016. As a result, massive purge took place among Turkish soldiers and civilians in NATO structures, which horrified the Czech personnel serving alongside them and most likely caused serious long-term damage to the credibility of Turkey as a reliable ally. The questions frequently heard in the Czech defence sector regarding Turkey concern how effective the Turkish military will be in the future given the wholesale purges. What has this done for the morale of the Turkish armed forces? Will the Turkish military now be focused internally on the process of loyalty checks? And how will it influence the interoperability within NATO? All of this remains to be seen but the prospects are looking increasingly bleak. ${ }^{15}$

With Great Britain out of the EU, Turkish move to a position of a rather untrustworthy partner within NATO and with US under new leadership implementing the "America first" policy, the Czech defence policy is currently facing new challenges from its external environment - for the first time coming not only from the potential enemies, but from would be partners and allies.

12 Elliot Ackerman. Turkey Is a Dictatorship Masquerading as a NATO Democracy. Available at: http:// foreignpolicy.com/2017/03/29/the-dictatorship-in-natos-clubhouse-erdogan-kurds-turkey/

13 The Trouble(s) with Turkey: Turkey and NATO. 2017. Available at: http://www.cgai.ca/the_troubles_with_ turkey_and_nato

14 Bershidsky, L., 2017. Turkey's Troubled NATO Status. Available at: https://www.bloomberg.com/view/ articles/2017-03-14/turkey-s-nato-status-grows-more-troubled

15 Nato's second biggest army just bought nearly $£ 2$ bn of weapons from Russia. 2017. Available at: http:// www.independent.co.uk/news/world/europe/nato-army-buys-2-billion-dollars-weapons-from-russiamilitary-deal-a7942521.html 
While the collective defence mechanism remains paramount for safeguarding the national security, prudent defence policy dictates both to rely more on our ability to become more self-sufficient in terms of political decision making and military capability development and to contribute more to the enhancement of the EU defence cooperation.

\section{DOMAINS OF ADAPTATION OF THE CZECH DEFENCE POLICY}

\section{Political Domain}

Since 2014 we can see clear political commitment to boost the capabilities and capacities of our armed forces and effort is being made on political and military levels in order to keep the defence system and armed forces relevant and fit for future challenges.

In the political domain, in particular, the Czech defence policy was dominated during the last year by the outcomes of the NATO Warsaw Summit, chiefly by assurance measures, deterrence, enhance forward presence and many other aspects.

In practical terms, the NATO commitments influenced the amendment to the Defence Strategy of the Czech Republic 2017. The Czech government approved this document in March 2017. It creates a solid groundwork necessary for enhancing the overall resilience of the government bodies and agencies, local administrations and citizens against the negative impacts of the unstable security environment and supports their ability to withstand it.

The defence strategy includes several important measures, such as the establishment of new units and the rise in the number of soldiers by 5000 . Furthermore, for international crisis management operations, the Czech Republic will, depending on the nature of crisis, deploy a land brigade task force without rotation for a six-month period. In the event that such a task force is not deployed, the Czech Republic will be able to deploy simultaneously a sustainable battalion and a company size land task force, or an air force component, with rotation, for international crisis management operations. ${ }^{16}$ This is a significant increase in the level of political-military ambitions. So far, the previous Defence Strategy counted with the deployment of Czech brigades to secure NATO's collective defence only. For international crisis management operations, the Czech Republic was able to assign the forces and assets only up to the size of a battalion task force rotated after a six-month period.

In this context, the defence strategy provides the required top-down political guidance for the defence planning process which is the principal tool for enhancing the capability delivery, strengthening the defence potential of the country and reinforcing the armed forces' fighting ability. It establishes a clear vision both for the development of the defence system and the armed forces' capability. It frames the right things to do and

16 Defence Strategy of the Czech Republic 2017. The Ministry of Defence of the Czech Republic - MHI Prague, 2017. ISBN 978-80-7278-702-9 Available at: http://www.army.cz/images/id_8001_9000/8503/ DefenceStrategy2017.pdf 
creates one important precondition for an effective defence provision for our country and security of our populations.

Nevertheless, there are several aspects which still keep some level of ambiguity or are not presented at all in our updated Defence Strategy. The ambiguity is related to the response to an armed conflict, which threatens the sovereignty and territorial integrity of the Czech Republic; in such a situation, all forces and assets of the Czech Armed Forces (CZAF) are employed, including an option to invoke conscription. More should be done to transfer this rather unclear political statement into an exact political commitment and military task in terms of war time structure of our armed forces.

Unfortunately, the Defence Strategy does not offer measures for further institutional innovation including the rationalisation of all MoD internal processes and processes at the level of state administration related to the provision of defence. In practice, it means that the creation of effective and efficient structures and processes which will make sure that all the right things will be implemented in right way is a compromise to a significant extent. Despite the fact that the period of resource driven strategy seems to have passed, responsible political behaviour should ensure that we will get out most of tax payer money spent on defence.

These above-mentioned deficiencies in our Defence Strategy, however, have been creating sort of dilemma for policy makers. There is no doubt about the continuing worsening of the security situation of the Czech Republic and its allies - comprehensively reflected in the updated security and defence strategies, demanding capable armed forces and higher level of resources. But there is no clear and commonly shared vision among policy makers and military leadership on the future force posture (role of the CZAF and structure of its wartime establishment), as well as on capabilities this country should exactly invest in.

This sort of dilemma is underscored by so far limited ability of the MoD administration to implement the already agreed plans and modernisation programs and of our military to justify their capability development needs for future modernisation based on holistic and appropriately detailed operating concepts. ${ }^{17}$

Under these circumstances, the authors of this article feel growing scepticism that more resources allocated to defence are going to increase our defence potential and armed forces fighting capability. ${ }^{18}$ This attitude is underpinned also by several examples of failed modernisation efforts in the past.

\section{Military Domain}

Even during the 2016/2017 time period, the military has continued to fulfil political tasking from Wales and newly also from the Warsaw Summit. This applies especially to the implementation of commitments stemming from the Readiness Action Plan (RAP).

17 Kontrolní závěr z kontrolní akce 16/05: Peněžní prostředky určené na pořizování vybrané techniky Armády České republiky. Nejvyšší kontrolní úr̆ad. Praha, 2016.

18 Lukáš DYČKA, Přiležitost nebo krize? Výzvy současné obranné politiky ČR, 1. část. Natoactual.cz Officiální portál Informačního centra o NATO. 2017.Available at: http://www.natoaktual.cz/prilezitost-nebo-krizevyzvy-soucasne-obranne-politiky-cr-1-cast-pya-/na_analyzy.aspx?c=A170605_110709_na_analyzy_m02 
The CZAF also increased assignments of units to NRF (over 800 soldiers in 2016). In this framework, the Czech Republic supports the Forward Enhanced Presence in the Baltic states starting 2018 by employment of one mechanized company within the German unit to Lithuania and later then one mortar platoon to Latvia as part of the Canadian contingent.

In 2016, the Czech Republic deployed, already for the third time, 75 soldiers and four SAAB 39C Gripen aircrafts (the fifth as a reserve) from the $21^{\text {st }}$ Tactical Air Force Base Čáslav to provide air defence coverage over the territory and waters of Iceland.

Regarding the operations deployments the Czech government decided in 2016 that not only NATO's collective defence but also Afghanistan, Mali and fight against the IS group are among the main priorities of the Czech military abroad in 2017-2018. Besides that, numerous other smaller missions are traditionally supported by the CZAF (e.g. Kosovo, Bosnia, Sinai, etc.).

The biggest unit is to operate again in Afghanistan. In 2017, the Czech army expects to have 270 soldiers there. Another 20 are to be designated, as of now, for the protection of the Czech embassy in Kabul. The Czechs will continue with their focus on the protection of the allied forces and training of their Afghan counterparts. ${ }^{19}$

The military is continuing its mission in Mali in 2017 by sending its second most numerous contingent there in history. Altogether 60 persons are to serve there. The bulk of this force will make part of the EU training mission. Ten soldiers will work in the staffs of the Malian mission headed by the United Nations (UN).

As a part of the package deal of selling L-159 light combat aircraft to Iraq, the Czech Republic sent an air force consultancy team to help train the local air force. This represents probably the greatest contribution to fighting the Islamic State (IS). Additional capabilities were either already deployed (field surgical team in Mosul) or will be sent during 2017 (five to ten persons strong military police training team).

Other notable project regarding interoperability with allies envisaged in 2017 is planned with the affiliation of the Czech $4^{\text {th }}$ Rapid Deployment Brigade with German $10^{\text {th }}$ Armoured Division and Rapid Response Forces Division. This integration (which involves also Romania's $81^{\text {st }}$ Mechanized Brigade) was been agreed upon on the $15^{\text {th }}$ February 2017 under NATO's Framework Nation Concept. The affiliation of the $4^{\text {th }}$ Rapid Deployment Brigade is to be organized at the tactical level of the German Division, which will allow the already planned exercises and trainings to be used as entry points for further practical cooperation. The affiliation will be mainly focused at common activities of staff elements and affiliated units, common training, education and harmonization of military requirements, procurement and logistical support. ${ }^{20}$ In practical terms, this

19 Gov't approves military's foreign priorities for 2017-2018. Prague Daily Monitor. Available at: http://www. praguemonitor.com/2016/04/19/govt-approves-militarys-foreign-priorities-2017-2018

20 Letter of Intent between The Ministry of Defence of the Czech Republic and the Federal ministry of Defence of the Federal Republic of Germany. 2017. Available at: http://www.army.cz/assets/informacniservis/zpravodajstvi/smlouva-cr-srn_1.pdf 
affiliation was heavily criticized ${ }^{\mathbf{2 1}}$ by Czech opposition parties as well as by influential magazines such as Foreign Policy ${ }^{22}$ due to misunderstanding of its implications. This affiliation has been wrongly seen as putting the CZAF under the German command and integrating both armies, while in reality it will be rather focused on systematic common training with German soldiers at divisional level, which the CZAF (due to the fact, that the highest-level units are only brigades) cannot train on its own. Additionally, it is of utmost importance for command and staff development (rather than for soldiers in basic assignments). ${ }^{23}$

Considering the broad spectrum of operational deployments and level of military cooperation, it could be argued, that the Czech Republic is reflecting 360 degree approach to defence and in its nature it is balancing its commitments toward NATO, EU and UN.

In terms of the long-term adaptation, the CZAF pursues the implementation of its Development Concept 2025. ${ }^{24}$ Despite the increasing defence budget, several envisaged acquisition programmes and initiatives are being postponed due to both lack of clarity of military specifications and prolonged acquisition process.

It seems that the CZAF struggle with deficiencies stemming from the long-standing neglect of the importance of sustained maintenance and development of credible defence capability will be even more difficult to overcome that it was previously written down in CZAF Development Concept 2025.

The defence capability development is inevitably tied to procurement of material. During the studied period, the pace of modernisation was sluggish. The originally envisaged strategic programmes were subject to change in terms of scope and timelines. This applies particularly to acquisition of multipurpose helicopters, artillery systems and mobile air defence radars (MADR). Nevertheless, there are several projects, e.g. 20 pieces of command and control armoured wheeled vehicles PANDUR (8x8) and 42 vehicles of similar purpose based on the TITUS platform (6x6), 40 IVECO special CBRN supporting vehicles, several thousand sets of body armour and helmets. It is obvious that successful acquisition embraces less sophisticated, smaller or cheaper programmes. The reason for that is the missing military personal responsible for setting requirements, insufficient project management capacity in the civilian part of the MoD (age and sheer numbers of project managers) and excessive fear of punishment accompanying any disputable decision making related to contract signature. The newly adopted strategy ${ }^{25}$ goes in right

21 Opravdový hnus. EuroWehrmacht. Kolaborantské hovado. Stropnický přidružil české vojáky k německé divizi a toto nám na to řekli Bělobrádek, Schwarzenberg či Lorencová. 2017. Available at: http:// www.parlamentnilisty.cz/arena/monitor/Opravdovy-hnus-EuroWehrmacht-Kolaborantske-hovadoStropnicky-pridruzil-ceske-vojaky-k-nemecke-divizi-a-toto-nam-na-to-rekli-Belobradek-Schwarzenbergci-Lorencova-477344

22 Germany is quietly building a European army under its command. 2017. Foreign Policy. Available at: http:// foreignpolicy.com/2017/05/22/germany-is-quietly-building-a-european-army-under-its-command/

23 Písemná reakce ministra obrany na interpelaci poslance Filipa. 2017. Available at: http://www.psp.cz/ doc/00/12/33/00123315.pdf

24 CZAF Development Concept 2025 known under the Czech abbreviation KVAČR (Koncepce výstavby Armády České republiky).

25 Armament and defence industry cooperation strategy not available in English version 
direction but the authors of this article expect effects of most of the measures rather in long-term than quick wins.

\begin{tabular}{|l|l|l|l|l|l|}
\hline & $\begin{array}{l}\text { Main Battle } \\
\text { Tanks MBT }\end{array}$ & $\begin{array}{l}\text { Armed Combat } \\
\text { Vehicles ACV }\end{array}$ & Artillery Systems AS & $\begin{array}{l}\text { Combat Aircrafts } \\
\text { CA }\end{array}$ & $\begin{array}{l}\text { Attack Helicopters } \\
\text { AH }\end{array}$ \\
\hline 1993 & 1617 & 2315 & 1516 & 227 & 34 \\
\hline 1995 & 1011 & 1451 & 893 & 215 & 36 \\
\hline 1997 & 952 & 1367 & 767 & 143 & 36 \\
\hline 1999 & 938 & 1219 & 754 & 114 & 34 \\
\hline 2001 & 652 & 1211 & 648 & 97 & 34 \\
\hline 2003 & 541 & 1235 & 528 & 125 & 34 \\
\hline 2005 & 298 & 747 & 362 & 103 & 32 \\
\hline 2007 & 181 & 580 & 321 & 38 & 38 \\
\hline 2009 & 178 & 490 & 259 & 42 & 29 \\
\hline 2011 & 166 & 494 & 244 & 38 & 25 \\
\hline 2013 & 123 & 501 & 182 & 39 & 24 \\
\hline 2015 & 123 & 442 & 179 & 39 & 17 \\
\hline 2017 & 120 & 439 & 179 & 35 & 17 \\
\hline CFET* Ceilings & 957 & 1367 & 767 & 230 & 50 \\
\hline *Treaty on Conventional Armed Forces in Europe & & & \\
\hline
\end{tabular}

Figure 1: Main Weapon Systems of the Ministry of Defence of the Czech Republic ${ }^{26}$

While the problems with modernization programs are widely medialized and have become politically visible as a welcome tool for critics of the current ministry of defence leadership, the problems do not stop here and include other areas as well.

The most critical realm is the command and control function. During the more than last two decades there was a mistaken logic of "slashing fat", i.e. cutting the higher officer corps positions and reducing command structure perceived at that time as unnecessary. The original intension, allegedly, was to introduce lean management in military business and turn the rank pyramid inherited from the Warsaw Pact era. Through today's lenses it seems that as well as the "fat", the Czech Republic slashed also a substantial proportion of "brain" of its military. Therefore, the Czech military has currently limited ability to provide balanced military advice to politicians, capacity for long term strategic planning and to prepare, plan and conduct larger military operations (small joint operations - SJO). The way out is, for instance, to reinforce the strategic level of decision making by separating operational and conceptual functions within the General Staff, reintroducing war games and staff military drills into daily military business and military

26 Ministry of Defence, 2017. Available at: http://www.mocr.army.cz/dokumenty-a-legislativa/cisla/cisla-pocty--souhrny-95091/do 
education. ${ }^{27}$ More specifically, one of the steps might be the creation of organisation within the General Staff tasked with the planning and control of military crisis operations on the territory of the Czech Republic.

Furthermore, the military should react to the different strategic assumption - increasingly shortening the reaction time for managing crisis. Therefore, the peacetime establishment of armed forces must be capable of building up and mobilizing robust command and force structures in the case of war faster than in the past. The first mobilization exercise was conducted in April 2017 when more than 300 reservists were involved and process and procedures verified. The scope of this exercise was definitely not militarily significant, nevertheless, it was a much higher political gesture symbolizing the changing attitude to defence.

In the area of doctrines, there was a great deal of effort during the last year dedicated to elaborating further on the CZAF Development Concept 2025 into lower level conceptual documents (land forces development concept, air forces development concept, military police development concept, etc.), which more or less progressed successfully over the year. However, there is still no firmly set hierarchy of strategic conceptual documents within the MoD. This sometimes leads to overly creative drafting of this sort of documents - simply saying, the respective services are producing too many of them. What is probably even more puzzling, it is the absence of an overreaching operational concept ${ }^{28}$ (capstone concept) from which the long-term capability operational needs of CZAF should stem. The pace of works on this document - even though still ongoing - is rather inadequate.

Based on the aforementioned lower level conceptual documents, the development programs of respective services (air forces, land forces, etc.) have been currently (2017) outlined and approved by the Ministry of Finance and implemented through the midterm plan for the 2019-2023 period.

Modernisation of the aging infrastructure was one of the priorities of the CZAF Development Concept 2025. Nevertheless, implementation of this priority was not done in a systematic manner during the last year. As rather an ad-hoc solution at the end of the fiscal year, unspent financial resources for modernization of military equipment were reallocated for the purpose of repairs of barracks and other facilities. While undoubtedly important, this task is thus exploited to a subsidiary measure.

An ambitious plan is designed to recruit a high number of professional soldiers (1800 new soldiers in 2016 and 2000 in 2017) as well as members of Active Reserves (to reach

27 Zapomněli jsme, že smyslem armády je boj, varuje šéf elitních speciálních sil Karel Řehka. 2017. Aktualne. cz Available at: https://zpravy.aktualne.cz/zahranici/zapomneli-jsme-ze-smyslem-armady-je-boj-varujesef-elitnich/r 642f4b0cd35411e6be7d002590604f2e/?redirected=1495017887

28 An operational concept known under the Czech abbreviation KOPOS (Koncepce operačního použití ozbrojených sil). 
5000 in 2025 - currently less than 1300 positions are filled). Currently over 5000 positions are not filled - some units are only at the $65 \%$ level of manning.

\section{Administrative Domain}

Administrative domain comprises internal MoD functions and structures. During the last year, there were several issues potentially with a considerable level of risk for proper functioning of the MoD. The first of these issues stems from the Act on Civil Service, passed by the Parliament in 2015. Its implementation lowered the attractiveness of civilian servant positions at the MoD due to disbalance between higher level of qualification requirements and uncompetitive salaries. There are two trends keeping their pattern - ageing of the personnel and rising numbers of unfilled civilian positions, some of them critical (Defence Policy and Strategy Division and Armament Division). Nevertheless, the true ticking bomb with long-term consequences is the ageing of the civilian personnel. The structure is largely populated with former military personnel enjoying military pension and related benefits, for whom even less paid civilian position is acceptable. While it may be beneficial in terms of experiences and institutional knowledge on the downside, it puts considerable barriers for innovative and out-of-the-box way of thinking. Additionally, it creates a "personnel bubble" when "old-timers" are leaving without proper (and younger) replacement.

Possible solution may be twofold. Firstly, a conceptual solution must be sought in the form of, for instance, comprehensive long-term human resource strategy (currently non-existing) reflecting and balancing the needs of the MoD, career development opportunities and labour market limitations. ${ }^{29}$ Secondly, it should be accompanied both with more competitive salaries and motivating sets of benefits.

Fundamental function for the implementation of defence policy goals is acquisition. This function has deteriorated during the years of economic austerity. Processes were not adapted properly and personnel competencies gradually declined. The New Armament Strategy is in the process of implementation. It aims to introduce the best practices - SMART acquisition, sound project management and proper management of life cycle. The preferred principle for material procurement is "government to government". It should minimise corruption and create additional security guarantees by following the proverb "By buying our weapons, you also buy our friendship".

The second most significant function is Human Resource Management. It should be able to implement personnel policy in its complexity and to guarantee skilled and motivated people for each function as stipulated in the new Act on Civil Service. The new career management for professional soldiers should deal with the understaffing of command and force structures, lack of motivation, declining knowledge, and inadequate age structure of military personnel.

\section{Economical Domain}

While there was a considerable resistance to spend 2\% of GDP on defence among the coalition parties, after the visit of the Czech minister of defence in the US in early

29 The Bundeswehr Personnel Strategy 2016 could serve as an inspiration for the Czech Republic. 
May 2017, it was announced that reaching this level of expenditures is likely in $2025 .^{30}$ Nonetheless, so far there has been only commitment of the Czech government from 2014 to increase the defence spending progressively to reach $1.44 \%$ GDP in $2020 .{ }^{31}$ But even our ambition to reach the recommended NATO benchmark is not entirely new. The Czech Republic has a sort of valuable lessons from the past when the $2 \%$ of GDP were being met. At that time (1993-2005) ${ }^{32}$ it resulted in overheated procurement of equipment, which did not always fit the operational needs, and as a consequence there were not enough money to operate it and some of this equipment was put on storage (e.g. subsonic fixed-wing fighter L-159).

But the amount of expenditures is only one part of the equation. Political representation in the Czech Republic should be seriously concerned about the effective and efficient use of the allocated resources. In this respect, the internal structure of the defence budget is of utmost importance. The so-called 50/30/20 formula for defence expenditures, with 50 percent of the budget allocated for personnel costs, 30 percent for operations and maintenance, and 20 percent for modernization was long seen as an ideal goal in the Czech Republic. However, defence expenditures in 2016 in the proportions of $59 / 30.5 / 10.5$ clearly indicate that the investment level is still unsatisfactory and the pattern of modernisation of our armed forces is rather slow. ${ }^{33}$

However, it seems that the current intensions to allocate these fast-growing funds are following the opposite, yet in a way also mistaken logic. The most worrying recent trend is the ambition to invest $30 \%$ of the MoD's annual defence budget in the procurement of new equipment, which was promised to the US partners in 2017. If we take into consideration that our ability to estimate the life cycle cost in a reasonable way is very limited, it means - most likely - the operating costs will even increase. There is clearly a considerable level of risk that by this approach the readiness and preparedness of Czech Armed Forces will be put in serious question. And at the same time the personal costs are expected to be under constant pressure due to the increased recruitment, rising salaries and competition over personnel on the market.

In addition to this fundamental set of benchmarks within the NATO context, there are also other criteria followed, e.g., by the EU or the European Defence Agency (EDA), respectively. They emphasize the need for enhancing the investments in research and development (R\&D), which should comprise $2 \%$ out of all MoD's investments, and multinational cooperation through cooperative modernisation programs (35\% out of all money spent on modernisation of main acquisition programs) and $20 \%$ out of the total R\&D. ${ }^{34}$

30 Ministr Stropnický: Vrtulníky české armádě dodají USA nebo Itálie. 2017. Aktualne.cz. Available at: http:// www.lidovky.cz/ministr-stropnicky-vrtulniky-ceske-armade-dodaji-usa-nebo-italie-p9d-/zpravy-svet. aspx?c=A170502_224422_In_zahranici_ELE

31 Czech Coalition Agreement. 2014. http://www.army.cz/en/ministry-of-defence/newsroom/news/czechgovernmental-coalition-sign-agreement-on-the-progressive-increase-of-the-defence-budget-101455/

32 Figure 2.

33 KDU-ČSL: Navýšení výdajů na obranu je v zájmu bezpečnosti naší země. 21.4.2017. Available at: www. parlamentnilisty.cz

34 FIOLT D. The CARD on the EU defence. European Union Institute for Security Studies. QN-AL-17-010-2A-N. ISBN 978-92-9198-517-3, ISSN 2315-1129 DOI:10.2815/173153 


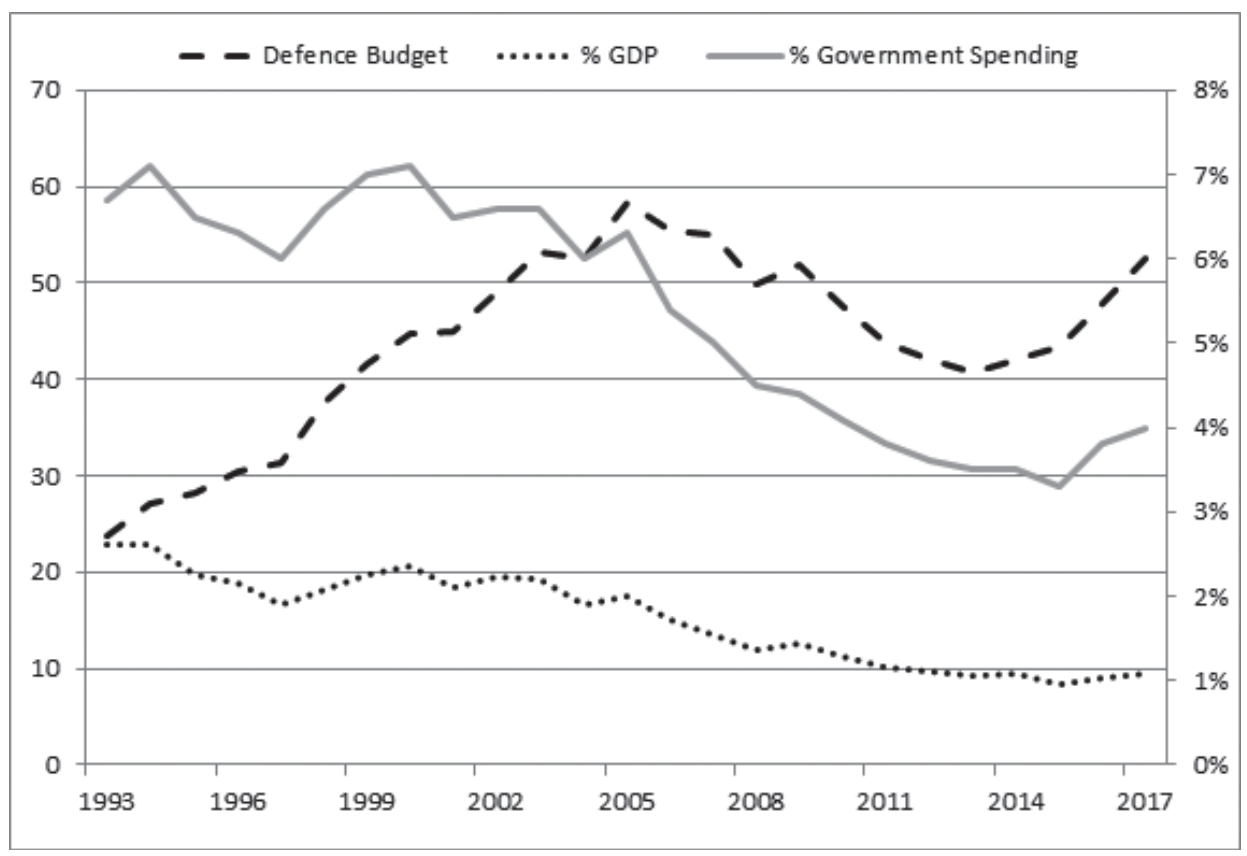

Figure 2: Defence Spending of the Czech Republic ${ }^{35}$

\section{Societal Domain}

The defence potential of every state is traditionally based upon the Clausewitzian notion of the trinity of "people, army, and government". ${ }^{36}$ While "army" and "government" were covered in the previous chapters, it is the societal domain that is often overlooked. It is widely recognised that personnel represent the most significant resource for any given organisation and that cannot be echoed more than by the defence sector. It was acknowledged that there is a significant underfinancing in the area of military equipment and infrastructure. ${ }^{37}$ However, we argue that the most devastating effect caused by the shrinking defence budget in the past was in the human resource domain. Figure 4 depicts the evolution of the quantitative characteristics of personnel. The trend of slashing personnel, however, ended in 2014.

The societal domain is also tied to the holistic way of understanding the term "resilience". It includes the informational domain and also activities related to general public. Since the end of the Cold War, it has been a general trend in Europe to phase out mandatory military conscription. Recently, however, there have been some setbacks in

35 Ministry of Defence, 2017. Available at: http://www.mocr.army.cz/dokumenty-a-legislativa/cisla/cisla-pocty--souhrny-95091/do

36 Christopher Bassford and Edward J. Villacres. 2011. Reclaiming the Clausewitzian Trinity. Available at: https://www.clausewitz.com/readings/Bassford/Trinity/TRININTR.htm

37 Czech Armed Forces Development Concept 2025 
this trend. While it is true that some European countries reintroduced conscription, in the last years, most of the EU and NATO members still rely on some sort of volunteer or professional armed forces (see Figure 3). Also in the Czech Republic, this discussion of reintroducing conscription was notably present during the last year. It might be potentially reflected in the programmes of certain political parties for the upcoming 2017 parliamentary elections (Christian Democratic Union-Czechoslovak People's Party, etc. ${ }^{38}$ ).

\begin{tabular}{|c|c|c|c|}
\hline Country & Status & Service Length & Conscripts \\
\hline Austria & Compulsory & 6 months & N/A \\
\hline Belgium & Abolished 1994 & $-\cdots$ & $\cdots$ \\
\hline Bulgaria & Abolished 2008 & $\cdots$ & $\cdots$ \\
\hline Croatia & Abolished 2008 & $\cdots$ & $\cdots$ \\
\hline Cyprus & Compulsory & 14 months & 10,700 \\
\hline Czech Rep & Abolished 2005 & $\cdots$ & $\cdots$ \\
\hline Denmark & Compulsory & $4>12$ months & 1,250 \\
\hline Estonia & Compulsory & $8>11$ months & 3,000 \\
\hline Finland & Compulsory & $6>9>12$ months & 13,650 \\
\hline France & Abolished 1996 & $\cdots$ & $\cdots$ \\
\hline Germany & Abolished 2011 & $\cdots$ & $\cdots$ \\
\hline Greece & Compulsory & 9 months $>1$ year & 48,950 \\
\hline Hungary & Abolished 2004 & $\cdots$ & $\cdots$ \\
\hline Ireland & $\cdots$ & $\cdots$ & $\cdots$ \\
\hline Italy & Abolished 2004 & $\cdots$ & $\cdots$ \\
\hline Latvia & Abolished 2006 & - & $-\cdot$ \\
\hline Lithuania & Reintroduced 2015 & 9 months & 3,000 \\
\hline Luxembourg & Abolished 1967 & $\cdots$ & $\cdots$ \\
\hline Malta & $\cdots$ & $\cdots$ & $\cdots$ \\
\hline Netherlands & Abolished 1997 & $\cdots$ & $\cdots$ \\
\hline Poland & Abolished 2012 & $\cdots$ & $\cdots$ \\
\hline Portugal & Abolished 2004 & $\cdots$ & $\cdots$ \\
\hline Romania & Abolished 2006 & $\cdots$ & $\cdots$ \\
\hline Slovakia & Abolished 2006 & $\cdots$ & $\cdots$ \\
\hline Slovenia & Abolished 2003 & $\cdots$ & -- \\
\hline Spain & Abolished 2001 & $\cdots$ & $\cdots$ \\
\hline Sweden & Reintroduced 2018/19 & $9>12$ months & 4,000 \\
\hline UK & Abolished 1960 & $\cdots$ & $-\cdots$ \\
\hline
\end{tabular}

Figure 3: Conscription in EU countries*

* SIPRI, Institute for Security Studies EU, adapted by authors

38 KDU-ČSL: Navýšení výdajů na obranu je v zájmu bezpečnosti naší země. 2017. Available at: www. parlamentnilisty.cz 
A common denominator of all pro-conscription arguments in the Czech Republic was not to strengthen the national defence but rather to supplement the seemingly insufficient education of young population, both at schools and in the family. ${ }^{39}$

As a result of resilience enhancement suggested in the Audit of National Defence, ${ }^{40}$ the Czech MoD is seriously considering new initiatives aiming at strengthening physical fitness and developing fundamental knowledge and practical skills of young population related to tactical level basic military competencies. Instead of reintroducing the conscription model, the generally discussed idea is to improve cooperation and communication with associations, clubs and societies, such as volunteer firefighters, sport pilots, chasseurs, kennel clubs, and sport societies. This approach reflects historical experiences with organizations such as the Sokol movement (from the Czech word for falcon) founded in the second part of the $19^{\text {th }}$ century as an all-age gymnastics organization. It was based upon the principle of "a strong mind in a sound body". Sokol members also helped create the Czechoslovak Legions during WWI and formed local patrols that kept order after the disintegration of the Habsburg rule and during the creation of Czechoslovakia in October 1918.41

While the original plans endorsed in the Czech Armed Forces Development Concept 2025 expected reaching 24,162 soldiers, the newly adopted Defence Strategy 2017 added further 5000 of military personnel. Based on the evaluation of security threats and the ensuing risks, it states that it is essential, in the long term, to develop new units in order to enhance the combat capabilities, and thus increase the Czech Armed Forces personnel numbers by the aforementioned additional 5000 military professionals, but at the same time maintain the priority of providing adequate manning, equipment, armaments, training standards, and achieving full operational capabilities of the existing structures. The commitment to reach 5000 strong active reserves remains unchanged.

However, achieving this relatively high level of ambition faces considerable obstacles. Externally, there are worrying demographic and societal trends. Firstly, the increasing societal diversity as well as the multitude of possible individual choices characterise complex modern societies. As a consequence of this social change and the ensuing change of values, people have different expectations of modern working conditions, predictable career paths or opportunities to balance their professional and private life. Combined with an increasing individualisation and geographic mobility of both private life and work, this trend also affects leadership, communication and organizational cultures and structures of the CZAF.

There are also numerous other trends and factors influencing the ability of armed forces to attract suitable cohort of personnel on the open market, e.g., the aging appli-

39 Češi budou moci na vojenské cvičení, Čunek volal i po povinné vojně. Idnes. 2017. Available at: http:// zpravy.idnes.cz/cesi-budou-moci-na-vojenske-cviceni-cunek-volal-i-po-povinne-vojne-p9m-/domaci. aspx?c=A160113_125708_domaci_kop

40 Audit národní bezpečnosti. Government of the Czech Republic. 2016. Available at: https://www.vlada.cz/ assets/media-centrum/aktualne/Audit-narodni-bezpecnosti-20161201.pdf

41 Ministerstvo obrany chce zapojit občany do plnění úkolů ozbrojených sil. Denik.cz. 2017. Available at: http://www.denik.cz/z_domova/ministerstvo-obrany-chce-zapojit-obcany-do-plneni-ukolu-ozbrojenychsil-20170520.html 


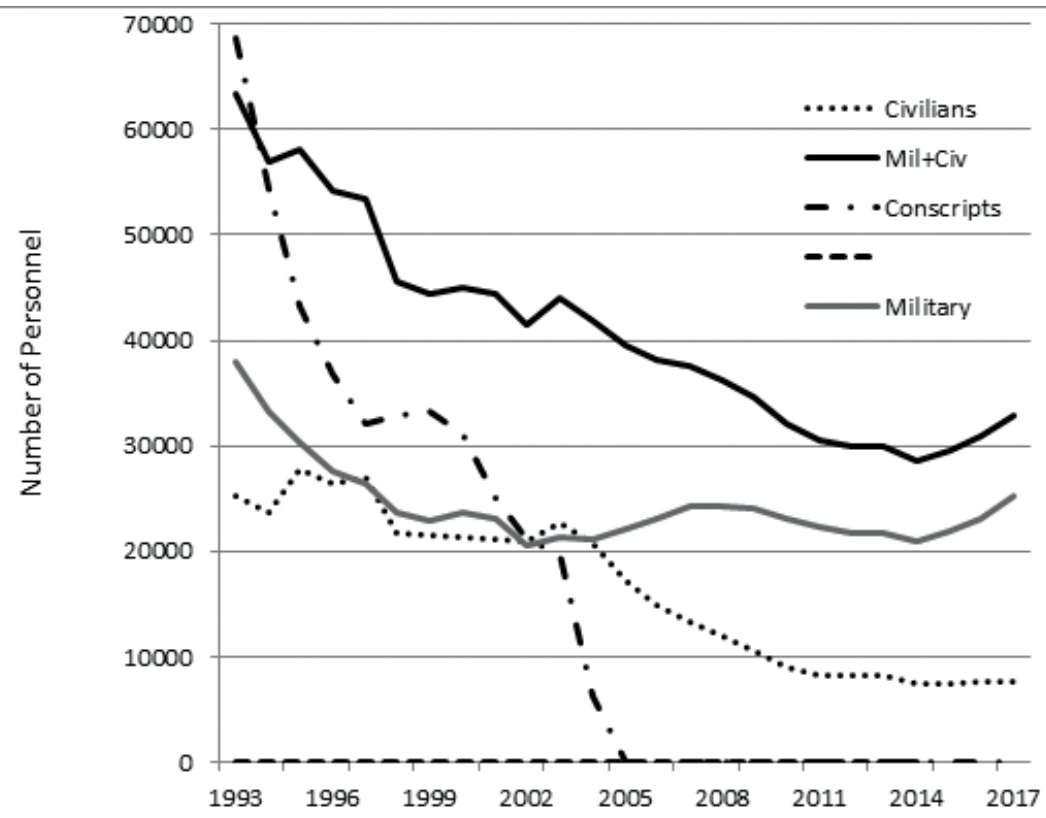

Figure 4 Personnel of the Ministry of Defence of the Czech Republic*

* Ministry of Defence,2017. Available at: http://www.mocr.army.cz/dokumenty-a-legislativa/cisla/cisla-pocty--souhrny-95091/do

cants for military service, educational expansion (more young people seeking academic education, thus being progressively unwilling to enlist to basic military assignments), declining general fitness and psychological abilities of population, and low flexibility of workforce, resulting in soldiers often refusing to serve in garrisons far from their homes. All of these factors will continue to present a challenge to the CZAF to recruit, qualify, develop, and maintain personnel.

Our human resource management needs to be more flexible and out-of-the-box thinking is required. The right policy response is to expand the draft to women, foreigners and in the long term to offset shortages of personnel by higher level of robotization and digilatization. With regard to foreigners, the potential and acceptable pool might especially consist of EU citizens (EU-wide recruitment).

The most significant disadvantage of the CZAF human resource management seems to be its lethargy, which is most apparent in constantly trying to hire people with very generic broad skills and qualities with no regard to actual needs of their future assignments and career paths. Simply, we need to have more flexible approach to people management. For example, adjust the physical selection requirements to the actual position being occupied (e.g., vastly different requirements on members of special forces vs. IT specialists); provide soldiers with attractive education useful not only in their military but also in the ensuing civilian career; offer rewarding career opportunities not only 
in vertical but also in horizontal directions; design effective set of benefits to enhance positive motivation; and invest heavily in the aging and obsolete military infrastructure. Furthermore, successful human resource management should not be built exclusively on salary and benefit increase, but it should be accompanied with the change in the organisational culture and shift of leadership priorities.

Strategic communication as a significant part of the societal domain has been "reactive" rather than "proactive" in the past. The result is alarmingly low knowledge of ordinary citizens about the defence sector. Only $20 \%$ of respondents in the public survey were able to guess the size of CZAF or defence budget correctly. The natural outcome is that just $43 \%$ of respondents are willing to participate in defence of the country in the case of war. ${ }^{42}$ The Ministry of Defence has currently commenced work on the Strategic Communication concept. One of the key preconditions is that it will be orchestrated with other ministries. However, the Ministry of Interior has the lead in this case.

An inherent part of the potential scenario is also the hybrid kind of activities targeting the countries' cyber space. Allies agreed during the summit meeting in Warsaw in 2016 to designate the cyber space as an official operational domain of warfare, along with air, sea, land, and space. Cyber security capability the Czech MoD is going to maintain and develop will embrace passive, preventive and reactive measures. ${ }^{43}$ The critical capability gap within the $\mathrm{C} 2$ domain is the secured line of communication in integrated national and multinational information environment which we are still unable to resolve effectively.

Despite the acknowledgment that societal resilience and cyber and strategic communication are essential elements of the Czech defence capability portfolio, more needs to be done, both conceptually and in practical terms. Additionally, more resources should be allocated toward these areas and holistic approach institutionalised - clear responsibilities and organisational arrangement should be established. Stove piping is not the way we should pioneer through because it would again create an unacceptable risk to our defence provision.

\section{CONCLUSION}

The authors of this paper intended to assess the defence policy of the Czech Republic in the past year (2016/2017). To do that, this article reviewed the Czech defence policy adaptation in the following domains: (1) political; (2) military; (3) administrative; (4) economic; and (5) societal, and it offers several ideas for its further improvement. In the beginning, also the most important external trends were assessed.

It seems that the Czech political leadership's attitude to defence matters has evolved over the last years. Additionally, Brexit, Turkey's changing position and the election of

42 "Armáda a veřejnost 2015" - Ministry of Defence.

43 The Long Term Perspective for Defence 2030. Prague 2015. Available at: http://www.army.cz/images/ id_8001_9000/8503/THE_LONG_TERM_PERSPECTIVE_FOR_DEFENCE_2030.pdf 
a new US president have reinforced this trend. The outcome of this might be split into several areas. First of all, the decline of defence budget has been stopped and hopefully will be reversed in the near future (from the current $1.06 \%$ to $2 \%$ of GDP by 2024), thus reaching the NATO benchmark of $2 \%$. Secondly, several strategic documents were amended to reflect new security realities and implications - chiefly, the Defence Strategy 2017, which is already based on a different set of strategic assumptions than the previous one. Thirdly, the capability of armed forces is a subject of reconsideration in order to enhance its preparedness and readiness. In addition, the defence system, as a whole, requires enhanced resilience and proper functioning in terms of mobilisation of all society resources.

Nevertheless, the implementation of the updated Czech defence policy still faces significant obstacles.

Authors: Josef Procházka, Ph.D., born in 1966. He is graduate of the Military Academy Brno. Later he served with the troops in the field of technological and automobile support, in staff positions at the General Staff and the Ministry of Defence and in the Institute for Strategic Studies in Brno. He completed his doctoral study in the programme Management of Defence of State. His military career was finished in 2007. Since 2011, he served as a defence advisor to the Czech Permanent Delegation to NATO. Currently, he acts as a director deputy of the Centre for Defence and Military Strategic Studies in Brno. He publishes in area of defence policy, sources management, defence planning, logistics and armaments.

Lukáš Dyčka, born in 1985. He studied Political Science and Security and Strategic Studies at the Faculty of Social Studies of Masaryk University graduating in 2011. Studied at the University of Oslo in 2008. Since 2013 works at the Centre for Security and Military Strategic Studies, University of Defence in Brno. Between 2014-2016 he worked consecutively as an Advisor to the Deputy Minister of Defence, Minister of Defence and the Deputy Minister - Head of the Defence Policy and Strategy Division. He specializes on Czech Defence Policy and Armed Conflict Research. In 2017 he recieved Eisenhower Fellowship in NATO Defence College in Rome.

How to cite:Procházka, Josef and Dyčka, Lukáš. Czech Defence Policy - Critical Assessment and Recommendations. Vojenské rozhledy. 2017, 26 (5), 41-60. DOI: 10.3849/2336-2995.26.2017.05.041-060. ISSN 1210-3292 (print), 23362995 (on-line). Available at: www.vojenskerozhledy.cz 


\section{Landmarks in Analysing Contemporary Conflicts: Between Tradition and the Need for Innovation Mezníky analýzy současných konfliktů: mezi tradicí a potřebou inovace}

\section{Alexandra Sarcinschi}

Abstract: The paper discusses the correlation between methodologies of conflict analysis and dynamics of international security environment and highlights the need to tailor these methodologies to the rapid sequencing of world events. The analytical approach starts with an overview on the general theory of conflict, whereupon the author focuses on the most widely used models of contemporary conflict analysis and summarizes the way they approach the same conflict, namely the recent events in Ukraine, in order to illustrate the advantages and disadvantages of each model. The final part of the paper develops, instead of conclusions, the correlation between the two analysed items and the way in which specific components of the methodologies can be adapted to the development of main characteristics of the international security environment.

Abstrakt: Článek se zabývá korelací mezi metodikami analýzy konfliktů a dynamikou mezinárodního bezpečnostního prostředí a zdůrazňuje potřebu přizpůsobit tyto metodiky rychlému sledu událostí ve světě. Analytický přístup začíná přehledem obecné teorie konfliktu; autor se následně zaměřuje na nejčastěji používané modely analýzy současných konfliktů a shrnuje způsob přístupu k témuž konfliktu, konkrétně nedávným událostem na Ukrajině, aby znázornil výhody a nevýhody jednotlivých modelů. Závěrečná část článku namísto závěru rozvíjí korelaci mezi dvěma analyzovanými body a způsob, jakým Ize konkrétní prvky metodik přizpůsobit vývoji hlavních charakteristik mezinárodního bezpečnostního prostředí.

Keywords: Conflict; Military Conflict; Political Conflict; Conflict Analysis; International Security Environment.

Klíčová slova: Konflikt; vojenský konflikt; politický konflikt; analýza konfliktů; mezinárodní bezpečnostní prostředí. 


\section{INTRODUCTION}

The sociological theory postulates that conflict has both integrative and disintegrative effects on social systems. This theory is not new. Lewis Coser has correlated structural functionalism to conflict analysis since the 1950s, but its validity is more visible now than ever because changes in the security environment prove both the centrifugal and centripetal powers of the conflict. Translating the terminology of the political geography (Richard Hartshorne, e.g.) to the strategic studies, the centripetal force translates into a capacity or an attitude that tends to unite people and to strengthen support for a state, while the centrifugal force has the effects of destabilizing and fragmentizing the nation state.

Of this very brief introduction to the conflict theory emerged an important landmark of conflict analysis, namely its interdisciplinary feature: in order to perform a coherent conflict analysis, one needs to examine not only sociology and geography, but also strategic studies, economics, statistics, military science, etc. ${ }^{1}$ In the following, the paper will present, along with the general theory of conflict, the most important landmarks in conflict analysis and will conclude by tailoring them to the evolving international security environment characteristics.

\section{The General Theory of Conflict}

Conflict, in its broadest sense, implies the existence of an antagonism and society itself is "dominated by a conflict of interest between those who have access to wealth, power and status and the rest". ${ }^{2}$ Conflict is intrinsic to any social system and its settlement may theoretically contribute to achieving and maintaining social stability. Six elements can be identified in conflict analysis: actors, causes, forms of manifestations, the nature of the goals set by the actors, means of carrying the action, and effects on society. It should be noted that each of these elements may support multiple changes according to changes taking place in society and, shifting the debate to the security studies, according to changes in the international security environment. There is no clear postulate whether the international security environment, through its continuing changing characteristics,

1 This is the subject of author's work that is to be found in both doctoral research activity (2004-2007) and published papers such as Tensions, Crises, Conflicts at the Beginnig of the Millenium (in original, Alexandra SARCINSCHI "Tensiuni, crize, conflicte la început de mileniu", in Lumea 2005. Enciclopedie politică şi militară (World 2005. Political and Military Encyclopedia), eds. Teodor FRUNZETI and Vladimir ZODIAN, Editura CTEA, Bucharest, 2005, pp. 86-98, ISBN 973-7601-20-3), Vulnerability, Risk, Threat. Security as a Psychosocial Representation (in original, Alexandra SARCINSCHI, Vulnerabilitate, risc, amenințare. Securitatea ca reprezentare psihosocială, Editura Militară, Bucharest, 2007, ISBN 978-97332-0739-9), and $21^{\text {st }}$ Century Atypical Conflicts (in original, Stan ANTON, Alexandra SARCINSCHI, Eugen SITEANU, Conflictele atipice ale secolului al XXI-lea, Editura Universității Naționale de Apărare "Carol I", Bucharest, 2015, ISBN 978-606-660-220-4).

2 "Conflict theory" in Steve BRUCE and Steven YEARLEY, The Sage Dictionary of Sociology, SAGE Publications, London-Thousand Oaks-New Delhi, 2006, pp. 46-47, ISBN 0-7619-7481-4 and 0-7619-7482-2. 
causes the changing in the conflicts' elements or a conflict triggers forces that transform the characteristics of the international security environment. The scholars widely agreed that there is a bi-univocal correlation between the characteristics of conflicts' elements and the characteristics of the international security environment.

Issues relating to the conflict were initially the subject of social philosophy and, later, sociology, although its roots are to be identified even in the works of Thucydides. From Niccolo Machiavelli and Thomas Hobbes - who argued that ideas and ethics are created in social interaction, they are not its predecessors, and they are used by parties in a conflict - to Lewis Coser - who postulates the social functions of the conflict that is part of human relations and not a sign of instability, but potentially engine of social change and innovation - theories of conflict brought to debates its causes, manifestations and effects on society.

Regardless of whether any of the above theories are used in conflict analysis, the conflict remains a dimension of human relations both within a state and between states.

Although the concept of conflict has a broad coverage, its meaning is often reduced to one dimension: the armed conflict. According to international humanitarian law, there are two main types of armed conflict: international armed conflicts, opposing two or more states, and non-international armed conflicts, between governmental forces and non-governmental armed groups, or between such groups only. ${ }^{3}$ In this regard, the experts of the International Committee of the Red Cross argue that, legally, there is no other type of armed conflict than those two and, even then, the two have common elements, and one of them can develop into the other type depending on factors prevailing at that time. The same experts, analysing the texts of the four Geneva Conventions of 1949 , concluded that any disagreements between the two states leading to the intervention of armed forces is an armed conflict, even when one of the parties denies the existence of the state of war. ${ }^{4}$ Also, an armed conflict restricted within a single state can be classified as international if another state intervenes in an armed manner supporting the rebel forces fighting against the government, but the armed conflict is considered to be non-international if violence takes place only between the government and the state's armed groups or just between such groups within a certain state.

Generally, most people use labels when designating various conflicts and identifying their sources. Such labelling refers generally to the conflict protagonists focusing on key differences among them. As a result, the conflict appears to be tribal, ethnic, racial, religious or linguistic, etc. Labels are used to categorize and easily identify a conflict, but it is likely that emphasizing just one factor may not be sufficient. Thus, a so-called ethnic

3 INTERNATIONAL COMMITTEE OF THE RED CROSS (ICRC), How is the Term "Armed Conflict" Defined in International Humanitarian Law?, Opinion Paper, March 2008, URL: https://www.icrc.org/eng/assets/ files/other/opinion-paper-armed-conflict.pdf

4 GENEVA ACADEMY OF INTERNATIONAL HUMANITARIAN LAW AND HUMAN RIGHTS, Rule of Law in Armed Conflicts Project (RULAC), URL: http://www.geneva-academy.ch/RULAC/qualification_of_armed_ conflict.php 
conflict may be related to socio-economic inequalities between different ethnic communities or lack of their access to decision-making in the respective state. ${ }^{5}$

Regardless of the type of conflict we refer to, its causes are multiple and may be the result of correlated dysfunctions in several areas of social life.

\section{Conflict Analysis Models}

At the beginning of 2000, Pyt S. Douma, former researcher at the Netherlands Institute of International Relations Clingendael, analysed the main causative factors of transition to the state of conflict: ${ }^{6}$

1. Political-military factors: processes involved in the formation of states and nations; the role of good governance, democracy, human rights, minorities rights; the role of ethnic-cultural factors; the centralization/monopolization of state power; mechanisms of power transition; the role of the armed forces; the proliferation of weapons within the state, etc.

Douma notes that the importance of political and military factors in the outbreak of a violent conflict has often been emphasized in contemporary literature, but the evaluations are not consistent and this dimension is treated like a "black box". In most cases, the used typology tried to classify various political systems on a scale from repressive and coercive regimes to democratic ones. In other cases, the nominal categories were used, such as the typology of Michael Brown on bad domestic problems, bad neighbourhood, bad leaders and bad neighbours. ${ }^{7}$ However, even if certain categories are useful for characterising political regimes, in order to achieve a more comprehensive analysis of political factors it is necessary to apply a more appropriate examination of the state's systemic properties and of the ways, in which the dominant political elite maintains relations with subordinated groups.

Assuming that states are able to provide a sufficient level of institutional capacity to prevent collapse, Douma argues that a number of criteria must be tested, such as those synthesized by K. J. Holsti, ${ }^{8}$ to assess the extent to which state power can be qualitatively sorted. Thus, we can argue that if the political regime is inclined to apply the mechanisms of diffusion of power, the possibility of triggering a conflict is greatly reduced, while the rapid transition of power between various socio-economic, religious or ethnic

5 DOUMA, Pyt S., The Origins of Contemporary Conflict. A Comparision of Violence in Three World Regions, Netherlands Institute of International Relations Clingendael, 2003, p. 7, URL: https://www.clingendael. $\mathrm{nl} /$ sites/default/files/20030900_cli_study18.pdf

6 Idem, pp. 10-11.

7 E. BROWN, Michael (ed.), The International Dimension of Internal Conflict, MIT Press, Cambridge, 1996, p. 579 apud Pyt S. DOUMA, The Origins of Contemporary Conflict. A Comparision of Violence in Three World Regions, 2003, p. 11.

8 K.J. HOLSTI, The State, War and the State of War, Cambridge University Press, Cambridge, 1996 apud Pyt S. DOUMA, The Origins of Contemporary Conflict. A Comparision of Violence in Three World Regions, 2003, p. 12. 
groups has the opposite effect. Stability is achieved by the existence of an undisputed and legitimate hierarchy.

2. Socio-economic factors: poverty and socio-economic inequalities; the territorial/ ethnic distribution of economic growth; employment and income; performance in human indicators; the (non-)discriminatory nature of socio-economic government policies, etc. ${ }^{9}$

Analysing a series of contemporary studies, Douma notes the role of poverty and socio-economic inequalities as the main triggers of violent conflicts, especially at national level. Currently, the theorists of conflict are speaking increasingly more about "fight for resources" as a concept encompassing all these factors. The dynamics of economic growth, the stagnation or decline of the national economy are other important causative factors of the conflict. Thus, increasing poverty and socio-economic inequalities determines a greater probability of a conflict's outbreak; in the same manner, the economic growth diminishes the risk of a conflict's outbreak.

3. External factors: the regional security setting; external military assistance (including international arms trade); financial aid to the parties involved; external economic interventions; external debt; structural adjustment programmes; International Monetary Fund and other multilateral or bilateral donors' conditions. ${ }^{10}$

Douma argues that external factors analysis must take into account a wide range of issues, such as those listed above, but it should take into account the political and military activities of other players not involved in the conflict. For example, if external military assistance (providing arms) increases, the probability of escalation also increases, or if economic intervention is consolidated, conflict may outbreak easier, and overall, as arrangements for regional security become unstable, the risk of triggering a conflict increases.

The conflict analysis model suggested by Douma identifies several stages of a conflict. The first stage is the tensing of the conflict, in which the parties threaten to use force and the conflict is not yet violent. The next stage is the escalation one, in which violence is introduced, the parties are organising and starting the systematic use of force. In the last phase, the de-escalating phase, the fight is ended and the conflict can be terminated or settled with a peace agreement that determines the success of the action. Within each phase, there are specific factors interacting and thereby influencing the conflict. ${ }^{11}$ Douma argues that since there are qualitative differences between the various factors, it is necessary to classify them as follows:

- Triggering factors: single events that can trigger a conflict, but they are not necessary, nor sufficient to explain it; they can take a different form in another phase of the conflict;

- Pivotal factors: single factors or configurations of factors that appear in the most phases of a conflict; in order to solve the conflict, the policy-makers must firstly consider this type of factors;

\footnotetext{
9 Ibidem

10 Ibidem

11 Ibidem, pp. 17-18.
} 
- Mobilizing factors: issues or processes around which conflict actors are grouped together. In each phase of the conflict, mobilizing of the involved groups can take different forms;

- Aggravating factors: these are factors that can interfere alongside the mobilizing and/or pivotal ones; their role is to enhance or reduce the other factors and they might have a different form in each phase of the conflict. ${ }^{12}$

Another model dedicated to conflict analysis was developed by the Heidelberg Institute for International Conflict Research since the beginning of 1990s, with constant methodological update since 2011. It is focused on political conflict defined as "a perceived incompatibility of intentions between individuals or social groups". ${ }^{13}$ According to the Heidelberg methodology, the variables are as follows: conflict actors (individuals, states, international organizations, non-state actors), conflict measures (actions and communications carried out by a conflict actor in the context of a political conflict), conflict items (tangible and intangible goods pursued by conflict actors by conflict measures, that are important for the existence of society as a whole or for its coexistence to a particular state or between states) and conflict intensity. ${ }^{14}$ For each variable, the methodology sets specific values resulting from a range of categories and scores whose aggregation determines the intensity of the conflict. The intensity is measured by five levels corresponding to the following types of conflicts: dispute, non-violent crisis, violent crisis, limited war and war. The first two types of conflict are classified by experts as non-violent and low intensity, while the last three are violent conflicts of medium or high intensity. ${ }^{15}$

Although the Heidelberg methodology provides a model of analysis that identifies five types of a conflict and levels of intensity, it does not offer the necessary details to identify the types of a violent conflict (whose range is vast), nor does it seek to develop a more comprehensive conceptual field. For instance, the 2017 analysis - Conflict Barometer 2016 - observes 402 conflicts, including 226 violent, 20 limited wars and 18 full-scale, but it does not provide an in-depth analysis of them in order to reveal the complex nature of contemporary conflicts. According to this analysis, the conflict in Donbass (Ukraine) is considered a fifth level intensity conflict (war), with elements of conflict (conflict items) including secession, system/ideology and resources. ${ }^{16}$

Another methodology for the analysis of conflict, which corresponds to a database of violent conflicts frequently used as a reference in strategic and security studies, is the one published by the Department of Peace and Conflict of the University of Uppsala, Sweden. It was fully developed in the mid-1980s and is constantly updated. The concepts of this methodology include armed conflict, interstate conflict, intrastate conflict, intrastate conflict with foreign involvement, non-state conflict, etc. An armed conflict is

12 Ibidem, pp. 17-18.

13 HEIDELBERG INSTITUTE FOR INTERNATIONAL CONFLICT RESEARCH, Conflict Barometer 2016, No.

25, online edition, Heidelberg, 2017, p. 6, URL: https://www.hiik.de/en/konfliktbarometer/pdf/

ConflictBarometer_2016.pdf

14 Ibidem, p. 7.

15 Ibidem, p. 6.

16 Ibidem, pp. 50-52. 
defined as "a contested incompatibility that concerns government and/or territory where the use of armed force between two parties, of which at least one is the government of a state, results in at least 25 battle-related deaths in one calendar year"; an armed conflict is distinguished by definition from a non-state conflict in which none of the warring parties are governmental. ${ }^{17}$ The methodology distinguishes between three types of conflict on the basis of the involved governmental stakeholders:

- Interstate conflict: "a conflict between two or more governments"; 18 a conflict is defined as interstate when the actor who first announced the incompatibility is a government party;

- Intrastate conflict with foreign involvement: "an armed conflict between a government and a non-government party where the government side, the opposing side, or both sides, receive troop support from other governments that actively participate in the conflict"; 19

- Intrastate conflict: "a conflict between a government and a non-governmental party, with no interference from other countries". 20

According to this methodology, whose definitions are the only public elements, the crisis/conflict in Ukraine, presented above in the vision of the Heidelberg Institute, is registered with four entries that address the following topics: government, with government incompatibility; Novorossiya with territorial incompatibility; Donetsk and Lugansk, both with territorial incompatibility. ${ }^{21}$ The analysis of events in Ukraine, although the Swedish methodology category includes intrastate conflict with external involvement, does not include a visible dimension of foreign intervention, which is present in another conflict analysis. ${ }^{22}$ The methodology of the Heidelberg Institute does not introduce this dimension either, as noted previously.

There is a high degree of difficulty in drawing a clear dividing line between the various types of conflict. Therefore, the following concepts should be used: "escalation" and "ex-

17 THE UPPSALA CONFLICT DATA PROGRAM - Definitions, Conflict, armed, Department of Peace and Conflict Research, Uppsala University, URL: http://www.pcr.uu.se/research/ucdp/definitions/\#Active

18 THE UPPSALA CONFLICT DATA PROGRAM - Definitions, Conflict, interstate, Department of Peace and Conflict Research, Uppsala University, URL: http://www.pcr.uu.se/research/ucdp/definitions/\#Active

19 THE UPPSALA CONFLICT DATA PROGRAM - Definitions, Conflict, intrastate with foreign involvement, Department of Peace and Conflict Research, Uppsala University, URL: http://www.pcr.uu.se/research/ ucdp/definitions/\#Active

20 THE UPPSALA CONFLICT DATA PROGRAM - Definitions, Conflict, intrastate, Department of Peace and Conflict Research, Uppsala University, URL: http://www.pcr.uu.se/research/ucdp/definitions/\#Active

21 THE UPPSALA CONFLICT DATA PROGRAM - Definitions, Ukraine, Department of Peace and Conflict Research, Uppsala University, URL: http://www.ucdp.uu.se/gpdatabase/gpcountry. php?id=161\&regionSelect=9-Eastern_Europe

22 See the following: STRATFOR (URL: https://www.stratfor.com/), CENTER FOR STRATEGIC AND INTERNATIONAL STUDIES (URL: http://csis.org/), CARNEGIE ENDOWMENT FOR INTERNATIONAL PEACE (URL: http://carnegieendowment.org), RUSI (URL: www.rusi.org), CHATHAM HOUSE (https://www. chathamhouse.org//), etc. 
pansion". ${ }^{23}$ The escalation is vertical and considers the level of violence and the increase of the number of participants in the conflict. The extension of a conflict is geographical and can be characterized as a horizontal growth of that conflict. These forms of conflict development occur when more states get involved in an intrastate conflict.

\section{Instead of Conclusions: The Evolution of the Security Environment and New Features of Conflict Analysis}

The correlation between the international security environment and the theoretical developments is an obvious assertion. However, it is particularly important to track the progress of this correlation in order to be able to update the methodologies of conflict analysis and even to provide pertinent forecasts. Still, there is an inadequacy between the pace of theoretical developments, on the one hand, and the dynamics of the security environment, on the other hand.

Events of the last 15 years have shown an increase of the incidence of conflicts in which state/non-state/individual actors have used force to achieve political and ideological goals, ${ }^{24}$ and among them there are non-militarized state actors whose rise is unprecedented. ${ }^{25}$ Conditions for intensification of this trend are correlated to the concomitant development of globalization and technology, which both allows and determines increasing connections and interdependence of global actors in remote areas, and also leads to development disparities between various countries and powers. The least developed countries, weak states and failed states are the most favourable environments for high risk terrorist groups, but also for violence, civil and sectarian wars. Other phenomena fostering the conflict potential of a country or region are: illegal migration; excessive urbanization of the population (overbuilding, poverty and social unrest); proliferation of weapons of mass destruction; race for water, energy and living conditions; climate change and the increased incidence of natural disasters; etc.

I can summarize and argue that the current security environment is characterized by certain factors such as: maintaining a state of insecurity and uncertainty (in par-

23 See Sebastian SCHUTTE and Niels B. WEIDMANN, "Diffusion Patterns of Violence in Civil Wars", in Political Geography, No. 30(3), 2011, pp. 143-152, ISSN: 0962-6298, and Olav OFSTAD, Conflict Management in International Relations: A Field Guide, Routledge, Oxon, 2015, ISBN 978-1-138-79418-4 (hbk) and 978-1-315-75938-8 (ebk).

24 Steven C. WILLIAMSON, From Fourth Generation Warfare to Hybrid War, US Army War College, Carlisle Barracks, 2009, pp. 13-15, URL: http://indianstrategicknowledgeonline.com/web/FROM\%2OFOURTH\%20 GENERATION\%20to\%20hybrid.pdf

25 THE GENEVA CENTRE FOR THE DEMOCRATIC CONTROL OF ARMED FORCES (DCAF), Armed Non-State Actors: Current Trends \& Future Challenges, DCAF Horizon 2015 Working Paper no. 5, Geneva, 2015, URL: www.dcaf.ch/content/download/53925/812465/file/ANSA_Final.pdf 
ticular by terrorist, propaganda, false news, post-truth, etc.); strategic shocks ${ }^{26}$ (ISIL expansion); the prevalence of non-state actors in conflict relations at the beginning of this century; the emergence and persistence of ungovernable regions (North Africa, Middle East, etc.); technological development and undifferentiated and non-discriminatory access to new technologies; etc. Moreover, there are actions of force that gain legitimacy on the basis of previous events recognized by the international community and also so-called new forms of conflict leading to the assumption of a new generation of armed conflict/military action/war (already beyond the $5^{\text {th }}$ generation of war up to the $6^{\text {th }}$ or $7^{\text {th }}$ generations?) and new forms of conflict (irregular or hybrid conflict - annexation of Crimea, secession war in Eastern Ukraine, ISIL actions in the Middle East). The methodological risk induced by these developments lies in overloading the terminology of conflict analysis and using forms without substance in the desire to "keep up" with a highly dynamic international environment.

All of these security trends begin to manifest simultaneously in certain regions and, in some cases, may even be manipulated by certain actors in the respective region. In this context, the conflicts, and especially the armed ones, acquire new dimensions and characteristics that determine post-factum changes especially at the level of theoretical component of conflict analysis methodologies. Therefore, beyond its interdisciplinary nature, the conflict analysis has an intrinsic feature that hinders its responsiveness to the increasing dynamics of the international security environment. If some classes of the methodology's elements - such as methods and techniques for collecting empirical data and techniques and procedures of data processing - do not change in the long term, others should be adapted continuously to the challenges in the short and medium term: part of the theoretical enunciations and theoretical construction or reconstruction procedures based on empirical data that underlie the development of typologies, explanations and predictions. In the case of the contemporary military phenomenon, which has involved a stronger and stronger asymmetric character over the last decade, the methodology of contemporary conflict analysis must consider the threat's asymmetric, hybrid and/or concealed character and build theoretical enunciations enabling the adequacy of the analysis to the dynamics of reality.

26 A comprehensive overview on these concepts is to be found in ANTON, Stan, "Conceptual Insights of Strategic Shock and Strategic Surprise", in Strategic Impact, No. 1/2013, pp. 58-67, ISSN 1841-5784, e-ISSN 1842-9904, ISSN-L 1841-5784. 
Author: $\quad$ Alexandra SARCINSCHI, Ph.D., is Senior Researcher at the Center for Defence and Security Strategic Studies from the "Carol I" National Defence University, Bucharest, ROU. Her main areas of interest are as follows: contemporary concepts and theories on security and defence; social and psychosocial key-factors of security; main international security organizations and their impact on Romania's national security.

\section{How to cite:}

SARCINSCHI, Alexandra. Landmarks in Analysing Contemporary Conflicts: Between Tradition and the Need for Innovation. Vojenské rozhledy. 2017, 26 (5), 61-70. DOI: 10.3849/2336-2995.26.2017.05.061-070. ISSN 12103292 (print), 2336-2995 (on-line). Available at: www.vojenskerozhledy.cz 
Peer-reviewed

\section{Czech Foreign Fighters in the Ukrainian Conflict: Legal Aspects and Propagandist Use}

\section{Čeští zahraniční bojovníci v ukrajinském konfliktu: právní aspekty a využití v propagandě}

\section{Miroslav Mareš}

Abstract: This article deals with the phenomenon of Czech foreign fighters in the Ukrainian conflict, mostly from the point of view of the propagandist use and from the point of view of the Czech penal law. Both issues are interconnected, because according to the Czech law, service in foreign armies or in terrorist entities can be penalised. On the other hand, foreign fighters can be assessed as an important propagandist element and their participation in the conflict can strengthen the political position of the warring party. This tension between these legal impacts and the propagandist use creates the main theme of this article. The concept of hybrid warfare frames the current development. The author comes to the conclusion that the legal consequences pose only a limited obstacle for the propagandist use.

Abstrakt: Tento článek se zabývá fenoménem českých zahraničních bojovníků v ukrajinském konfliktu, a to především z hlediska využití v propagandě a z pohledu českého trestního práva. Obě témata jsou vzájemně propojena, protože podle českých zákonů může být působení v zahraniční armádě nebo v teroristických subjektech trestáno. Na druhé straně Ize zahraniční bojovníky hodnotit jako důležitý prvek propagandy a jejich účast v konfliktu může posílit politickou pozici válčící strany. Toto napětí mezi právními dopady a propagandistickým využitím představuje hlavní téma tohoto článku. Koncepce hybridního válčení tvoří rámec aktuálního vývoje. Autor dochází k závěru, že právní důsledky představují pouze omezenou překážku pro propagandistické využití.

Keywords: Foreign Fighters; Propaganda; Radicalisation; Cyberspace; Czech Republic, Ukrainian Crisis.

Klíčová slova: Zahraniční bojovníci; propaganda; radikalizace; kyberprostor; Česká republika; ukrajinská krize. 


\section{INTRODUCTION}

Foreign fighters are currently an important phenomenon of armed conflicts. Due to this reason, they are also a subject of research in security and strategic studies and interconnected disciplines, ${ }^{1}$ including the security law. ${ }^{2}$ The Czech Republic has been facing the problem with foreign fighters in the Ukrainian conflict since 2014. The aim of this article is to analyse the propagandist use of Czech foreign fighters within the framework of hybrid warfare. This propagandist use is partially limited by legal penalisation of foreign fighters' activities according to the Czech law. An adaptation of propaganda of the warring parties and their allies to this situation (including manipulation of some information) is researched and explained in the article. The identification of the real scope of presence of Czech citizens in Ukraine is currently not possible due to lack of credible data, however, a general overview of this issue based on accessible sources will be included.

\section{ANALYTICAL AND METHODOLOGICAL FRAMEWORK: FOREIGN FIGHTERS AS ACTORS OF HYBRID WARFARE}

Foreign fighters on both sides of the Ukrainian conflict can be understood as actors of hybrid warfare in two dimensions. Firstly, due to their direct military involvement in the conflict, secondly due to their propagandist use. This "dual-use" is nothing new. The presence of foreign fighters in military forces served as a propagandist expression of international solidarity with the warring party many times. Mobilisation of new recruits was a subsidiary goal of such recruitment. The existence of international brigades on the Republican side during the Spanish Civil War between 1936-1939 can be mentioned as an example. It was propagated during this war and it is celebrated within leftist movements up to the present. The real situation in these units, though, can be different from their idealised image. ${ }^{3}$ On the other hand, criticism toward foreign fighters, who can be perceived as "bad guys" by the international or domestic audience, can be used in counter-propaganda. For example, brutal activities of the Islamic extremist foreign fighters

1 MALET, D. Foreign Fighters. Transnational Identity in Civil Conflicts, Oxford University Press, Oxford 2013, 9780199939459.

2 DE GUTTRY, A. - CAPONE, F. - PAULUSSEN, CH.: Introduction. In DE GUTTRY, A. - CAPONE, F. - PAULUSSEN, CH. (eds.): Foreign Fighters under International Law and Beyond. The Hague: Asser Press, 2016, pp. 1-8. ISBN: 978-94-6265-098-5.

3 BAXELL, R.: Myths of the International Brigades. Bulletin of Spanish Studies: Hispanic Studies and Researches on Spain, Portugal and Latin America. 201491 (1-2), pp. 11-24. ISSN: 1475-3839 (print), 14783398 (online). 
during the Bosnian War in the 1990s encouraged the Serbian feeling that the Serbian engagement in this war had a "just cause". 4

This propagandist perception can be researched also in the case of the conflict in eastern Ukraine. This conflict started in March 2014 and it is still ongoing, despite the second Minsk agreement about ceasefire from February 2015. Foreign fighters have been fighting on both sides of the conflict since its beginning. ${ }^{5}$ Several Czech citizens joined the separatist units as well as the Ukrainian nationalist units. ${ }^{6}$ The involvement of foreign fighters in the Ukrainian conflict is reflected in the media sphere, including new social networks.

Mass internet-based propaganda is an important element of the concept of the so-called hybrid warfare. Exact conceptualizing of this phenomenon is a subject of discussions in scientific and other expert circles. " "The interconnection of propagandist, subversive, insurgent, paramilitary, espionage, energy manipulation, and similar activities, both within the traditional dimensions of security and in cyberspace" ${ }^{\prime 8}$ seems to be an important definitional element of hybrid warfare.

The war in eastern Ukraine is presented as a model form of the current hybrid warfare (including hybrid threats aiming at actors who are indirectly engaged in armed operations). ${ }^{9}$ The foreign fighters' issue has not been discussed in the research on hybrid warfare up to now in a deeper way. However, this issue is immanently included in the media and the cyber-space dimension of this concept. Foreign fighters in the Ukrainian conflict create a specific threat to the West, ${ }^{10}$ including the Czech Republic.

The authors from the International Centre for Counter-Terrorism in the Hague divide the threat of foreign fighters into four categories described in the following chart:

4 COPLEY, G. - MILETIC, D. - TRIFUNOVIC, D. Terrorism. Global Network of Islamic Fundamentalist's - Part II Modus Operandi - Model Bosnia. Banja Luka: The Republic Secretariat for Relations with the International Criminal Tribunal in the Hague and War Crimes Research, 2004.

5 REKAWEK, K. Neither "NATO's Foreign Legion" nor the "Donbass International Brigades:" (Where Are All the) Foreign Fighters in Ukraine? [online]. Warsaw: The Polish Institute of International Affairs, 2015, [cit. 2017-06-28, available at: https://www.pism.pl/files/?id_plik=19434

6 MAREŠ, M. - VISINGR,L.2015. Zahraniční bojovníci v soudobém ukrajinském konfliktu. Politické vedy. [online]. 2015, 18 (1), pp. 86-106. ISSN 1335-2741 [cit. 2017-06-18], available at: http://www. politickevedy.fpvmv.umb.sk/userfiles/file/1_2015/MARES_VISINGR.pdf

7 STOJAR, R. Vývoj a proměna konceptu hybridní války. Vojenské rozhledy. 2017, 26 (2), 44-55. ISSN 1210-3292 (print), 2336-2995 (online). [cit. 2017-06-18] Available at: http://www.vojenskerozhledy. cz/selektivni-vyhledavani/kategorie-clanku/ozbrojene-konflikty/vyvoj-a-promena-konceptuhybridni-valky

8 MAREŠ, M.: Increasing resilience of the Czech Republic to hybrid threats. In Hybrid Warfare: A New Phenomenon in Europe's Security Environment [online]. 2nd edition. Praha - Ostrava: Jagello 2000, 2016. pp. 24-28. ISBN 978-80-904850-5-1 [cit. 2017-06-18], available at: http://data.idnes.cz/soubory/ na_knihovna/A161212_M02_029_HH16_PP-EN-V1.PDF

9 GALEOTTI, M. Hybrid War or Gibridnaya Voina? Prague: Mayak Intelligence, 2016, ISBN: 978-1-36556541-0.

10 MAREŠ, M.:Foreign Fighters in Ukraine: Risk Analysis from the Point of View of NATO. In REKAWEK, K. (ed.): Not Only Syria? The Phenomenon of Foreign Fighters in a Comparative Perspective. Amsterdam Berlin - Washington: IOS Press, 2017, pp. 31-39. ISBN: 1874-6276 (print), 1879-8268 (online). 


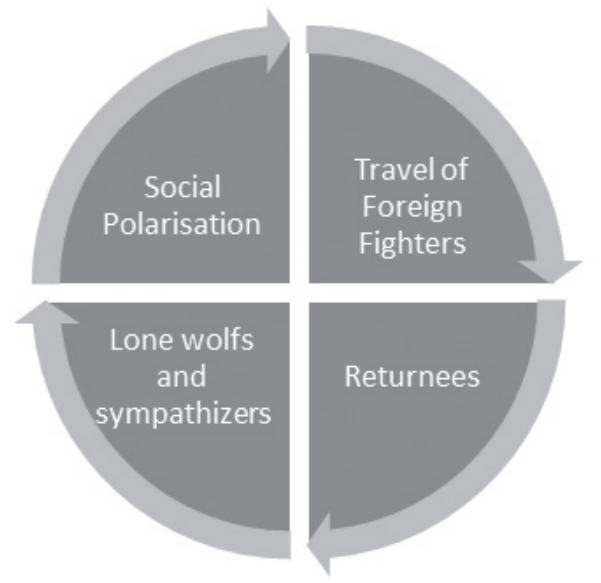

Source of the chart: REED, A. - POHL, J. - JEGERINGS, M.: The Four Dimensions of the Foreign Fighter Threat: Making Sense of an Evolving Phenomenon [Online]. The Hague: International Centre for Counter-Terrorism, 2017, p. 3. ISSN: 2468-0486 [cit. 19. 9. 2017], available at: https://icct.nl/wp-content/uploads/2017/06/ICCT-Reed-PohlThe-Four-Dimensions-of-the-Foreign-Fighters-Threat-June-2017.pdf

This chart was elaborated mostly for the purposes of analysis of jihadist foreign fighters, ${ }^{11}$ however, it can be useful also in the case of the Czech foreign fighters in the Ukrainian conflict. Still, the real scope of travelling, military presence and tactical importance of the Czech foreign fighters in the Ukrainian conflict is difficult to assess, mostly due to lack of trustworthy data. However, the image of these fighters and their propagandist use are possible and reasonable subjects of research, which can contribute to the understanding of the current hybrid threats. The sector of the social polarisation (see above) is researched in this article. The propagandist use of the military activities of foreign fighters as well as the propagandist use of their penalisation (as "martyrs") are important drivers of social polarisation.

The first and main research question of this article is:

$Q$ 1: How are the Czech foreign fighters in the Ukrainian conflict covered by various actors of the current media scene?

It is important to mention that the propagandist use is partially limited due to the legal situation of foreign fighters from the point of view of the Czech law. The threat and the reality of penalisation are also included in reports about these fighters. Because of this fact, the second research question is:

11 REED, A. - POHL, J. - JEGERINGS, M.: The Four Dimensions of the Foreign Fighter Threat: Making Sense of an Evolving Phenomenon [Online]. The Hague: International Centre for Counter-Terrorism, 2017, ISSN: 2468-0486 [cit. 19. 9. 2017], available at https://icct.nl/wp-content/uploads/2017/06/ICCT-Reed-PohlThe-Four-Dimensions-of-the-Foreign-Fighters-Threat-June-2017.pdf 
Q2: How are the legal consequences of activities of the Czech foreign fighters in the Ukrainian conflict covered?

The simple hermeneutic phenomenological approach will be used ${ }^{\mathbf{1 2}}$ within the context of media analysis and legal analysis. Media analysis is based on content analysis. According to Davies and Mosdell, the identification of the "event-driven" is an important part of such analysis, in the sense of studying "the coverage of a particular event that occurs over a specific time period". ${ }^{13}$ Activities related to the Czech foreign fighters in the Ukrainian conflict are researched in this article. A research set of media outputs was created based on the author's long time-research (2014-2017). The outputs from the traditional Czech media scene, from the pro-Kremlin Czech media scene, from the Ukrainian national media scene and from the "Novorossian" media scene are represented. The target audience is an important criterion of this categorisation. Information about the Czech foreign fighters in the Ukrainian conflict will be categorised within the analytical framework based on this division of the media scene.

Important phenomena of media reporting will be identified and they will be analysed from the point of view of tension between the propagandist use and the relation to legal consequences. The findings will be subsumed under the strategic theory ${ }^{14}$ related to the hybrid warfare concept.

As necessary conditions for this research, a short overview of accessible information about the participation of the Czech foreign fighters in the Ukrainian conflict and a basic description of the Czech law will be included in the following chapters of the article.

\section{PARTICIPATION OF THE CZECH FOREIGN FIGHTERS IN THE UKRAINIAN CONFLICT: A BASIC OVERVIEW}

As mentioned above, currently available data are not fully sufficient for a comprehensive description of participation of the Czech foreign fighters in the Ukrainian conflict. However, they can serve as a basic overview of trends and as a presentation of some of the most important events associated with this participation. The triangulation of data is in some cases very difficult, because sometimes only one or two original sources confirm the particular events (for example, the death of Ivo Stejskal, see below).

This article is focused on ethnic Czech fighters (at least partially, from mixed marriages) with Czech citizenship on both sides of the conflict. Many Ukrainians living in the Czech Republic (including people with double citizenship) served in Ukrainian units or were for-

12 KAFLE, N. P.: Hermeneutic phenomenological research method simplified, Bodhi: An Interdisciplinary Journal, 2011, 5 (1), 2011, 181-200, ISSN: 2091-0479.

13 DAVIES, M. M. - MOSDELL, N.: Practical Research Methods for Media and Cultural Studies: Making People Count. Edinburgh: Edinburgh University Press, 2006, p. 101 ISBN: 100-7486-2184-9.

14 YARGER, H.: Strategic Theory for the 21st Century. The Little Book on Big Strategy [online]. Carlisle: Strategic Studies Institute, U.S. Army War College, 2006, p. 2. ISBN 1-58487-233-0 [cit. 2017-06-26], available at: http://www.comw.org/qdr/fulltext/0602yarger.pdf 
ced to serve in these units (some of theme rejected to accept military call to active duty on the frontline).${ }^{15}$ On the other side of the front, at least one case of an ethnic Russian fighter with Czech citizenship was reported. ${ }^{16}$ Some other former separatist fighters from the post-Soviet republics (a. o. Belarus) are working on the Czech territory. Unclear is the participation of several Ruthenes from the Czech Republic in separatist units. ${ }^{17}$

The primary goal of this article is focused on fighters who declared their voluntary motivation for participation in the conflict and who are directly involved in battle operations. Battle or military operations do not include mass riots (as in Maidan or in Odessa) or isolated violence without direct links to the frontlines (for example, clashes between pro-Novorossian and Ukrainian activists in Prague). ${ }^{18}$

However, if we want to analyse the participation of foreign fighters on the Ukrainian side, the riots in Maidan at the turn of 2013/2014 are important for understanding these phenomena. Militant clashes in Kiev and other Ukrainian cities were connected also with the rise of right-wing extremist groupings (among others, the Right Sector - PS or the Social National Assembly - SNA). These groupings were supported by a part of the Western right-wing extremist scene, including neo-Nazis from the Czech Republic. According to Czech authorities, at least one group of neo-Nazi football hooligans travelled to Kiev in February 2014 to participate in clashes with political opponents. ${ }^{19}$

This "ethos of Nazi Maidan fighters" created conditions for the later engagement of "real" Czech foreign fighters in Ukraine. Their number is assessed around 5 persons ${ }^{20}$ and they came mostly from the Czech neo-Nazi scene. Some of them served in the Azov Battalion, later renamed to the Regiment of special purpose "Azov". In June 2015, one Czech citizen joined the Azov training camp, however, he left it after several hours (due

15 GINTER, J. Ukrajinci v Česku odmítají přebírat doporučenou poštu, nechtějí do války [online], Novinky 2014- 09-14 [cit. 2017-06-26], available at: https://www.novinky.cz/domaci/348109-ukrajinci-v-ceskuodmitaji-prebirat-doporucenou-postu-nechteji-do-valky.html

16 According to the sever HlídacíPes.org It is Kirill Belyakov, with permanent residence in Russian town Perm. He was a director of the Médea Public Relations agency. MIKEL, J. Další Čech ve válčícím Donbasu. $S$ kalašnikovem a v uniformě se tam fotil bývalý ředitel Médea PR [online]. HlídacíPes.org, 2017-06-09, [cit. 2017-06-26], available at http://hlidacipes.org/dalsi-cech-ve-valcicim-donbasu-s-kalasnikovem-a-vuniforme-se-tam-fotil-byvaly-reditel-medea-pr/

17 Only fighters from Slovakia, Poland, Hungary and Ruthenia allegedly served in the battalion I. G. Kundri in 2014 in Donbass. РЕСПУБЛИКА ПУДКАРПАТСЬКА(ПОДКАРПАТСКАЯ) РУСЬ: Русины-добровольцы на защите Новороссии [online], Vkontkate 2014-09-13 [cit. 2017-06-26], available at: https://vk.com/ public67712004

18 MAREŠ, M. Impact of Contemporary Ukrainian conflict on Violent Extremist Scene in EU Countries [online]. In HELLBACH, M. - KEMMESIES, U. (ed.): The Annual EENeT Conference 2014 and the succeeding Subgroup Meeting in March 2015 are part of the project. EENeT RAD 2014-2016 - Focusing Radicalisation June 2014 - Mai 2016, Bundeskriminalamt, Wiesbaden 2015 [cit. 2017-06-26], available at: https://www. bka.de/EENeT/EN/JouralEWPS/EWPS003.html?nn=55478

19 MINISTRY OF INTERIOR OF THE CZECH REPUBLIC, Report on extremism in the territory of the Czech Republic in the year 2014 [online], Prague, MVČR, 2015 [cit. 2017-06-27], available at: http://www.mvcr. $\mathrm{cz} / \mathrm{mvcren} /$ file/report-on-extremism-2015-pdf.aspx

20 LEGIEC, A.: Profiling Foreign Fighters in Eastern Ukraine: A Theoretical Introduction. In REKAWEK, K. (ed.): Not Only Syria? The Phenomenon of Foreign Fighters in a Comparative Perspective. Amsterdam - Berlin Washington: IOS Press, 2017, pp. 32-30. ISBN: 1874-6276 (print), 1879-8268 (online). 
to hard drill and due to his fear of real war). At least one fighter was a member of the "Right Sector" Volunteer Ukrainian Corps in 2015. ${ }^{21}$ In 2015-2016 these fighters, step by step, left Ukraine.

A larger Czech contingent served (or is still serving) in the armed forces of the Donetsk People's Republic (DNR). The number of these foreign fighters is assessed around 15 persons ${ }^{22}$ (some assessments are higher - around 20 persons). ${ }^{\mathbf{2 3}}$ The first Czech volunteers joined the separatist forces relatively early after the start of the armed conflict in Donbass, in spring 2014. Ivo Stejskal, former basic school teacher from the town Brno, held a speech to workers in Donetsk on the 18th June, 2014. He tried to mobilise the public in Donbass to fight against the regime in Kiev. Stejskal left Brno several weeks before this speech and joined the separatist Vostok Battalion. This speech was broadly covered by domestic and foreign media. ${ }^{24}$

On the 14th August, 2014, Ivo Stejskal and another Czech foreign fighter - Vojtěch Hlin$\mathrm{ka}^{25}$-were killed during an operation near the village Mijusinck. The Czech citizen living in Russia Oldřich Grund (allegedly cousin of Vojtěch Hlinka), who also served in the separatist units, reported about the circumstances of their death in September 2014. ${ }^{26}$ Grund served as a commander of the armed vehicle 2S9 Nona in the 1st Slavjansk Brigade of the DNR. He was awarded "Hero of Novorossia" on the 5th August, 2014 and received a knife with dedication from the separatist commander Igor Strelkov Girkin. ${ }^{27}$

In 2014-2015, several cases of Czech fighters on the separatist side were reported. In June 2015, establishing of the Czech-Slovak unit within the International Brigade 15 of the separatist forces was announced (this unit used the tradition of the International Brigade of the same number from the Spanish Civil War). This Czech-Slovak group originally consisted of 10 persons and it started recruiting new members at its own Facebook profile. ${ }^{28}$

21 Interview with a member of the Czech security community, 2016.

22 Ibid.

23 LEGIEC, A., p. 27-28.

24 EHL, M. - SOUČKOVÁ, M.: VIDEO: Přijel jsem vás bránit, říká Čech na demonstraci ukrajinských separatistů v Doněcku [online]. Ihned, 2014-06-19 [cit. 2017-06-29], available at: http://zahranicni.ihned.cz/evropaslovensko/c1-62384280-video-prijel-jsem-vas-branit-rika-cech-na-demonstraci-ukrajinskych-separatistuv-donecku

25 Vojtěch Hlinka (born 1967) was a former husband of the widow after famous Czech ice hockey couch Ivan Hlinka. He held the surname of the former husband. He was unemployed with huge debts in the Czech Republic. According to Czech newspapers, he got married again in Ukraine. BLÁHA, E. - URBANOVSKÁ, J. - IMK: Čech Vojtěch, který padl za Putina: Žil s exmanželkou Hlinky a vzal si jeho jméno! [online], Blesk, 2014-09-04 [cit. 2017-06-30], available at: http://www.blesk.cz/clanek/zpravy-krize-na-ukrajine/272353/ cech-vojtech-ktery-padl-za-putina-zil-s-exmanzelkou-hlinky-a-vzal-si-jeho-jmeno.html

26 TN.CZ - GARKISCH, D.: EXKLUZIVNĚ: Svědectví o smrti dvou Čechů na Ukrajině! [online], 2014-09-06 [cit. 2017-30-06], available at http://tn.nova.cz/clanek/zpravy/zahranici/exkluzivne-svedectvi-o-smrti-dvoucechu-na-ukrajine.html

27 SAVE DONBASS: Oldřich Grund..Občan ČR...Vyznamenaný hrdina Novoruska [online], Youtube, 2014-08-06 [cit. 30-06-2017], available at: https://www.youtube.com/watch?v=b_9dOSmTgZ0

28 PETROVIČ, J: V separatistickej armáde na Ukrajine založili česko-slovenskú jednotku. Hovorili sme s nimi [online], Aktuality.sk, 2015-06-08 [cit. 2017-30-06], available at https://www.aktuality.sk/clanok/277366/ exkluzivne-v-separatistickej-armade-na-ukrajine-zalozili-cesko-slovensku-jednotku-hovorili-sme-s-nimi/ 
Alleged Czech members of this unit, among others, included Martin Soukup (captain of the Czech army in reserve, major of the DNR army), Jiři Urbánek (a.k.a. Begemot, from a mixed Czech-Russian marriage, some sources identified Robin Urvany as Begemot's true name ${ }^{29}$ ) and Pavel Botka (a. k. a. Kavkaz, from a mixed Chechen-Czech marriage). Slovak members were Martin Sojka Keprta, Richard Branický and Mario Reitman, with unclear participation of Michal Böhm and Štefan Potocký (they may have served in other separatist units)..$^{30}$

However, the real activity of this unit is questionable. According to the information of Slovak and Czech journalists from 2016 and 2017, several Czech and Slovak veterans are still in Donbass, however, their military affiliation is unclear. A part of them are ready to fight again, a part of them declare economic activities on behalf of the DNR. ${ }^{31}$ They were in contact with the so called Representative Centre of the DNR (Zastupitelské centrum DNR), registered as an association in the Czech Republic. This association was banned by the court of the first instance in Ostrava in 2017. ${ }^{32}$

A returnee (allegedly Erik E., a.k.a., Gardista DNR; former soldier of the Czech army) was charged by the Czech police in June 2017. This man tried to join the Czech army after his return from Donbass. ${ }^{33}$ A Czech citizen, allegedly veteran of the KFOR mission and member of the paramilitary group Czechoslovak Soldiers for Peace Alojz Polák (a. k. a. Georgii Donbas Novorusia) is serving in the Republican guard of the DNR ${ }^{34}$ in 2017. A relatively new activity was announced by the Czech pro-Kremlin emigrant in Russia, Petr Mikhalu (formerly Michalů). He is trying to establish a new Czech-Slovak military unit in Russia in 2017, with the goal to use this unit for the "liberation" of the Czech and Slovak Republics from the "occupation of the EU and the NATO and Islam". Mikhalu is also active in supporting the separatists in Donbass. However, his activity seems to be only a propagandist project without real impact. ${ }^{35}$ In case of re-intensification of the conflict in Donbass, a new wave of the Czech foreign fighters can be expected.

29 MÁCA, R.: Ovlivňování a radikalizace paramilitární ruské páté kolony uvnitř ČR [online], Blog Idnes, 201702-23 [cit. 2017-07-05], available at http://maca.blog.idnes.cz/blog.aspx?c=586666

30 BENČík, J.: Kto zo Slovenska bojuje ako žoldnier na Ukrajine? Blog Denník N, 2015-12-17 [cit. 2017-06-30], available at: https://dennikn.sk/blog/321012/

31 FORRÓ, T. Naši chlapci v Donbase. Babie leto u československých separatistov [online], Denník N, 201612-01 [cit. 2017-06-30], available at https://dennikn.sk/622947/nasi-chlapci-v-donbase-babie-leto-uceskoslovenskych-separatistov/

32 ČTK: Soud zrušil zastupitelské centrum Doněcké lidové republiky. České noviny, 2017-06-28, available at: http://www.ceskenoviny.cz/zpravy/soud-zrusil-zastupitelske-centrum-donecke-lidoverepubliky/1501741 [cit. 2017-07-01].

33 KUNDRA, O.: První trest za válčení na Donbase? Obvinění pro muže, který se přidal k proruským separatistům. Respekt 28 (24), p. 26. ISSN: 0862-6545.

34 MÁCA, R.: Věří konspiračním teoriím, fandí Zemanovi, odešel bojovat za proruské separatisty [online], Blog Idnes. 2017-05-11 [cit. 2017-07-05], available at http://maca.blog.idnes.cz/blog.aspx?c=603636

35 MIKHALU, P.: Petr Mihalu. V kontakte, 2017-07-03 [cit. 2017-07-03], available at: https://vk.com/ id322842380 
LEGAL ASPECTS OF FOREIGN FIGHTERS' ACTIVITIES IN UKRAINE FROM THE POINT OF VIEW OF THE CZECH LAW

Service in foreign armies is not generally prohibited according to the Czech law, however, it requires specific conditions or approval. According to Act No. 585/2004 Coll., on conscription and its ensuring (the Conscription Act), Czech citizens can serve in the armed forces of a foreign state after the approval of the President of the Czech Republic. This approval is not requested in the case of more citizenships or if military service is provided in the armed forces of a member state of an international organisation of collective defence (of which the Czech Republic is a member). ${ }^{36}$

Other forms of service in a foreign state's military forces are prohibited. The Criminal code of the Czech Republic states in paragraph 321: "Citizen of the Czech Republic, who contrary to another legal regulation performs service in the army or the armed forces of another state, shall be sentenced to imprisonment for up to five years. An offender shall be sentenced to imprisonment for three to ten years, if he/she commits the act referred to in Sub-section (1) in a state of national peril or state of war". ${ }^{37}$

The persecution of service in military forces of a non-recognised state is questionable from the point of view of the current Czech criminal law. ${ }^{38}$ The use of paragraph 409 of the criminal code (Relations Endangering Peace) is not adequate and it has not been tested by the Czech judicial system up to now. ${ }^{39}$ The application of new paragraphs 312a (Participation in a Terrorist Group) or paragraph 312e (Support and Propaganda of Terrorism) is possible in case of service in terrorist organisations with their own armies. The proposed change of the Czech criminal code in the "main" paragraph 321 was discussed in 2016. The goal of this change was to prosecute service not only in any state's military forces but also in the forces of a "foreign agent" (in the sense of a non-recognised entity). ${ }^{40}$ This amendment has not been adopted up to now.

While the attempt of a Czech citizen to serve in the so-called Islamic state was sentenced according to §312e Propaganda and Support of Terrorism in $2017,,^{41}$ the legal assessment of foreign fighters in the Ukrainian conflict is not sufficiently solved. The service in Ukrainian units which are subordinated to governmental structures (a. o. Regiment "Azov") was prosecuted under paragraph 321. The assessment of service in

36 JELÍNEK, J. et. al.: Trestni zákoník a trestní rád s poznámkami a judikaturou. Praha: Leges, 2015, ISBN: 978 80-87212-22-6, p. 390.

37 ACT NO. 40/2009 OF THE COL., CRIMINAL CODE [online], [cit. 2017-06-04], available at: http://www.ejtn. eu/PageFiles/6533/Criminal\%20Code\%20of\%20the\%20Czech\%20Republic.pdf

38 JELÍNEK, J. - IVOR, J. et al. Trestní právo Evropské unie a jeho vliv na právní rád České republiky a Slovenské republiky. Praha: Leges, 2015, ISBN: 978-80-7502-080-2, p.244.

39 MAREŠ, M. - VÝBORNÝ. Š: Foreign fighters z pohledu českého trestního práva [online]. The Science for Population Protection, 7 (2), 2015, pp. 1-11. ISSN 1803-635X [cit. 2017-07-05], available at: http://www. population-protection.eu/prilohy/casopis/30/210.pdf

40 KOZÁK, P. Nové možnosti trestného postihu cudzích bojovníkov? Niekol'ko poznámok k právnej úprave § 419a Trestného zákona. Právník, 155 (9), 2016, pp. 754-773. ISSN: 0231-6625.

41 KRAJSKÝ SOUD V PLZNI, Rozsudek 34 T 16/2016, 2017-02-24. 
freelance nationalist units (mostly the Volunteer Corps of the Right Sector) is not clear. Current attempts to apply "anti-terrorist" paragraphs against foreign fighters in the separatist armed forces ${ }^{42}$ have not been confirmed by valid court judgements up to now. However, discussions about possible breaking the law due to serving as foreign fighters in the Ukrainian conflict are typical of the whole time of this issue.

\section{MEDIA COVERAGE OF CZECH FOREIGN FIGHTERS IN THE UKRAINIAN CONFLICT}

Czech foreign fighters in the Ukrainian conflict are an attractive topic for various types of media. However, while fighters on the separatist side were discussed relatively in depth and frequently in mass media and available public new social media, fighters in nationalist units were known mostly in selected echo chambers in new social media, respectively closed right wing extremist circles. In fact, the activities of Czech fighters in governmental units were the clearest breach of the Czech law (see above). Information about the service of former (or current) Czech neo-Nazis might have been used as information to discredit the whole Ukrainian anti-Kremlin struggle. A deeper analysis is impossible due to these facts.

Fighters in separatist units were presented by pro-separatist media (on separatist territories, in Russia and in the Czech Republic) as well as in more or less pro-Ukrainian media in the Czech Republic, in Slovakia or in Ukraine. Some of them used their real names, some of them only nicknames. The above-mentioned speech by Ivo Stejskal in Donetsk in June 2014 was used for propaganda of the internationalisation of the separatist struggle. ${ }^{43}$ Perception of his "heroic death" serves for mobilisation of supporters of the Novorossian separatism in the Czech Republic. An example is the memorial act at the cemetery in Brno on the $29^{\text {th }}$ August, 2015, organised by the National Democracy, with the participation of communists and other political activists. This activity was propagated at its dedicated internet presentation of the National Democracy. ${ }^{44}$

Interviews and statements of the current Czech separatist fighters in Donbass are used for the purposes of spreading broader political messages. In separatist and Russian media, they try to explain their own motivation based on anti-Western prejudices and to show that many Czechs are opponents of the official pro-Western policy. ${ }^{45}$ At least one

42 KUNDRA, 2017.

43 BAGANOV, S. Доброволец из Чехии батальона Восток на митинге в Донецке [online], Youtube, $2014-$ 06-18 [cit. 2017-07-05], available at http://www.ovkscmfm.estranky.cz/clanky/2.-svetova-valka/r.i.p-ivostejskal.v-radach-opolcencu-padli-dva-cesi.html

44 NÁRODNÍ DEMOKRACIE: Na Iva Stejskala můžeme být hrdí, bojoval i za nás [online], 2015-08-31 [cit. 201707-05], available at http://narodnidemokracie.cz/na-iva-stejskala-muzeme-byt-hrdi-bojoval-i-za-nas/

45 CHARKOVA, M. 2015-10-24 [cit. 2017-07-05], available at: http://volos-news.ru/blog/43277939783/ CHeshskie-dobrovoltsyi---chest-i-doblest-soprotivleniya-Donbassa?utm_campaign=transit\&utm_ source=main\&utm_medium=page_0\&domain=mirtesen.ru\&paid=1\&pad=1 
interview with strong pan-Slavic accent ${ }^{46}$ was translated into the Czech language and it was published for the domestic audience by an alternative web called New World Order Opposition. ${ }^{47}$

The Czech mainstream media use an image of "strange losers" in the presentation of the Czech foreign fighters. Their domestic problems with law and with insufficient personal financial situation are popularised. ${ }^{48}$ In the Ukrainian mainstream media, Czech foreign fighters are even labelled as mercenaries. ${ }^{49}$ On the other hand, pro-separatist media reject such labelling, such as Ivo Stejskal's sister Monika Stejskalová in the interview with the alternative channel Medium Europe. ${ }^{\mathbf{5 0}}$

Mentioning legal matters is more typical of the mainstream media than of the alternative media. However, in the case of prosecution of the Czech foreign fighter in June 2017 due to a terrorist crime, the Czech version of the Russian news agency Sputnik criticised this legal assessment and it offered a positive image of the fighters in the DNR. ${ }^{51}$ In case of a trial, intensification of the activity of the pro-Kremlin spectrum can be expected.

\section{CONCLUSION}

The presence of Czech foreign fighters in the Ukrainian conflict created a specific security challenge to the Czech Republic and it shows some unclear parts of the current Czech law. This issue won media attention, mostly in relation to fighters on the separatist side. It was connected with a social polarisation in relation to the Ukrainian conflict in the Czech Republic. The struggle between pro-Western and pro-Kremlin scenes has an impact on the media coverage. The first research question can be answered individually according to the affiliation of the media. Pro-separatist media cover the pro-separatist fighters as heroes, Czech media, a. o., as losers and Ukrainian media as mercenaries. The question of Czech fighters on the Ukrainian side has not been perceived in the media in a broader scope up to now. Possible explanations could be in the limited source of

46 CZALENKO, А. Чехо-Словацкие добровольцы в Донбассе: Мы, славяне в Европе, - рабы англо-саксов [online]. UKRAINA.RU, 2015-10-19 [cit. 2017-07-06], available at http://ukraina.ru/ interview/20151019/1014588112.html

47 ČALENKO, A.: Česko-slovenští dobrovolníci na Donbase: My, Slované v Evropě, jsme otroky Anglosasů [online], 2017-10-26, [cit. 2017-07-06], available at: http://www.nwoo.org/2015/10/26/cesko-slovenstidobrovolnici-na-donbase-my-slovane-v-evrope-jsme-otroky-anglosasu/

48 HÁJEK, A.: Čeští bohatýři bojující v Donbasu: Tady je větší demokracie než u vás [online], Idnes, 201705-21 [cit. 2017-07-06], available at: http://zpravy.idnes.cz/donecka-lidova-republika-cesti-dobrovolnicibegemot-kavkaz-p4q-/zahranicni.aspx?c=A170518_104530_zahranicni_aha

49 ZHIROCHOV, М.: Чешские и словацкие наемники на Донбасce [online], On Press, 2017-05-25, [cit. 2017-07-05], available at: http://onpress.info/cheshskye-y-slovatskye-naemnyky-na-donbasse-95974

50 MEDIUM EUROPE: CZ: Ivo Stejskal separatist fighter Novorossia - Ukraine war [online], Youtube.com, 2015-03-03 [cit. 2017-07-06], available at: https://www.youtube.com/ watch?v=P5aBjySVAmA

51 PETROVÁ, J. Policie objevila českého „teroristu. Názor [online]. Sputnik, 2017-06-14 [cit. 2017-07-06], available at: https://cz.sputniknews.com/ceskarepublika/201706145465876-policie-cesky-terorista/ 
data and the fact that these people were affiliated with the right-wing extremist scene (this is a controversial issue from the point of view of pro-Western media). Regarding the second question, it can be concluded that legal issues are sometimes openly declared in the pro-separatist as well as in the mainstream media, but they can be also a reason for hidden activities of foreign fighters and their supporters. However, their impact on the propagandist use is limited.

Acknowledgement: This paper was written as part of the research project "Manipulative Techniques of Propaganda in the Age of the Internet" (MUNI/G/0872/2016), sponsored by the Grant Agency of the Masaryk University

Author: $\quad$ Prof. JUDr. PhDr. Miroslav Mareš, PhD., born in 1974. He is the guarantor of security and strategic studies at the Department of Political Science of the Faculty of Social Studies of Masaryk University in Brno. He focuses on the research of extremism and terrorism in the Central Europe. He is a member of the European network of experts in matters of terrorism (EENET). He has worked with the OSCE and participated in the counter-extremism and the counter-terrorism activities of the European Union. He is an author or co-author of more than two hundred publications (among other with Astrid Bötticher they wrote the book Theorien, Extremism - Konzepte, Restoring, issued in 2012, in Munich).

How to cite:

MAREŠ, Miroslav. Czech Foreign Fighters in the Ukrainian Conflict: Legal Aspects and Propagandist Use. Vojenské rozhledy. 2017, 26 (5), 71-82. DOI: 10.3849/2336-2995.26.2017.05.071-082. ISSN 1210-3292 (print), 23362995 (on-line). Available at: www.vojenskerozhledy.cz 
Information

\section{Typology and Analysis of Armed Conflicts}

\section{Typologie a analýza ozbrojených konfliktů}

\section{Richard Stojar}

Abstract: The text deals with the conflict analysis and the use of typology within its framework. The author sums up the most relevant methodological approaches and tries to highlight their limits in the analysis of the current conflicts, which have by far more different characteristic features than in the past. In modern military conflicts, the states often use private military companies and create illegal armed formations. Quite often, the conflict parties have a varied character and one can observe chaotic alliances of state and non-state actors with different interests and different views on the projection of power and the use of armed force. The text highlights the necessity of adaptation of the current methodological approaches or at least their components and the development and changes which take place in contemporary conflicts.

Abstrakt: Text se zabývá analýzou konfliktů a použitím typologie v rámci této analýzy. Autor shrnuje nejdůležitější metodické přístupy a snaží se poukázat na jejich omezení při analýze stávajících konfliktů, které vykazují mnohem více různých charakteristických rysů než v minulosti. Státy účastnící se moderních vojenských konfliktů často používají soukromé vojenské společnosti či vytvářejí nelegální ozbrojené formace. Strany konfliktu mají v mnoha případech odlišný charakter a lze pozorovat chaotické aliance státních a nestátních aktérů s rozdílnými zájmy a odlišnými názory na projekci moci a použití ozbrojené síly. Text upozorňuje na nutnost přizpůsobení současných metodických přistupů nebo alespoň jejich součástí a na vývoj a změny, ke kterým v současných konfliktech dochází.

Keywords: Conflict Analysis; Typology; UCDP; HIIK.

Klíčová slova: Analýza konfliktů; typologie; UCDP; HIIK. 


\section{INTRODUCTION}

In recent decades, the analysis of armed conflicts received a relatively high attention, both from the international institutions and organizations dealing with or entering into the ongoing conflicts and the academic and expert centres, which approach the research and analysis of conflicts more deeply from the theoretical point of view. Since the 1990s, high quality methodological tools were developed along with the resulting typology of conflicts that appropriately reflected the armed conflicts and wars in that period. At present, it is evident that the existing conflict research approaches do not fully reflect the current trends and even the most widely used typologies of conflicts begin to be lacking in certain respect. In principle, the nature of conflicting behaviour and conflict remains unchanged, broadly defined as a collision of interests relating to national values (territory, ideology, state power, regional supremacy).

The term conflict itself in its wider understanding includes a broader spectrum of incompatible objectives and a wider scale of behaviour applied in order to achieve them ${ }^{1}$; it is still a more frequently used term than war. The war, as the highest level of armed conflict, puts the primary focus on the role of power in order to achieve the political objectives, but in recent years it has become a term that is inadequately used or overused (e.g. the war on terror). On the other hand, it has become a term that is in many ongoing conflicts circumvented for pragmatic reasons and not applied in practical terms.

In recent years, there are several emerging trends that somewhat weaken the validity of the existing methodological concepts and typologies, and it is questionable whether these trends deserve response from the academic and expert environment. Many present conflicts have characteristics that make them difficult to classify, if we apply the current most frequently used criteria. It is not possible to claim that there has been a radical change, however, a number of characteristics are far more pronounced than they used to be in the past. Therefore, it is possible to assume that we can expect development of new typologies, which will be able to capture the positions and strategies of all respective actors in the monitored or researched conflicts.

Generally, it seems to be acknowledged that there is a long-term trend of still more prominent share of intrastate conflicts; these are, however, accompanied with still more frequent involvement of external actors, who often determine the principal parameters of the conflict and also establish a number of restrictions for the local actors. A problem lies in the fact that the existing approaches to the evaluation of conflicts are significantly influenced by the state-centric concept of international relations. For many of them, the state is the basic unit of analysis and majority of variables are tied to the state. This involves significant simplification where a number of actors escape description. The state-centric concept is interconnected with the geographical typology of conflicts, which is also insufficient. Very often, the entire territory of the state is indicated as the location of the armed conflict, which does not always correspond to reality. Many regional conflicts

1 SHEVCHUK, Z. Towards a Typology of Armed Conflict. In: KŘ́ž, Z., URBANOVSKÁ, J. (eds.) Examining Armed Conflict: Theoretical Reflections on Selected Aspects, Brno: Masaryk University 2014, p. 88. 
are strictly geographically limited, at least as far as the combat activities are concerned. The long-lasting Indo-Pakistani dispute over Kashmir has had the armed dimension solely in the disputed area throughout the recent decades. ${ }^{2}$ Similarly, the current conflict in the Donbass area, if we see it as a Ukrainian-Russian conflict rather than a conflict between the Ukrainian government and the separatist entities of DPR (Donetsk People's Republic) and LPR (Lugansk People's Republic), in its hot phase remains limited only to the delineated territory.

Practically, all existing typologies today use the concepts of state and non-state actors; for more precise analysis or classification, however, this division is not sufficient and there are also further breakdowns, which aim to identify better the positions and activities of various parties involved in the conflict. In the professional sphere, probably the most respected breakdown is according to the Uppsala Conflict Data Program (UCDP), distinguishing among three types of actors and two levels of conflict: 1) primary parties; 2) secondary supporting parties, non-warring; 3) secondary parties, warring.

This approach has the advantage of simplification, which allows for better description and capturing a large amount of data. The weakness of the concept lies in the fact that it does not fully conceive the dynamics of the conflict, which, in some cases, prevents its better understanding.

At the primary level, these are actors who declare mutually incompatible interests. It may be a government and a non-state actor in the case of an intrastate conflict or two governments involved in an interstate conflict.

The applicability of the definitions of a secondary actor is a bigger challenge. According to the UCDP, the secondary non-warring actor provides support for the primary actor, thus, in some way, affecting the development and progress of the conflict. ${ }^{3}$ The support, in this case, consists in the supplies of arms, finance, logistics, etc., but not in direct combat involvement of their own military units. Anything that is associated with the normal interactions between these states and is not provided with a direct intention to help in combat, is not seen as a support for the primary side even if this had a direct impact on the course of fighting (e.g., the supplies of food, strategic raw materials or fuel). Such support may come from neighbouring states, various organizations or even diaspora (e.g. Albanian diaspora, Kurdish diaspora in the respective local conflicts).

The secondary warring actors enter the conflict through direct military involvement on the side of one of the primary actors and can shape the respective side in the conflict. They share the same position in the incompatibility with the primary actor, but they are not directly participating in the formulation of incompatible interests. According to the UCDP typology, only a state may be the secondary directly involved, i.e. actively fighting, actor. In the case of an intrastate conflict, it means that this position can be occupied only by an external actor. The current situation also allows for an armed involvement of other actors on the side of the primary actors without sharing the position in the incompatibility. Typical representatives can be found in private military companies

2 JEONG, H-W., Understanding Conflict and Conflict Analysis. New Delhi: SAGE Publications 2011, p. 130.

3 The Uppsala Conflict Data Program, online edition, Uppsala, 2017, http://www.pcr.uu.se/research/ucdp/ definitions 
or other non-state actors with adequate military force and with specific, e.g. purely material, motives. ${ }^{4}$ In this respect, the protracted Second Congo War can be mentioned, considered to be the bloodiest conflict since the end of World War II, with 25 armed non-state actors fighting alongside the 9 African states involved. The shortcoming of the UCDP typology seems to lie in an inadequate account of the importance of certain national and non-state actors and its difficult applicability to analyses of a large number of current armed conflicts, where the two-level concept is often insufficient. ${ }^{\mathbf{5}}$

At present, the most widely used typology was also designed by the UCDP, defining the armed conflict itself as the competition on incompatibilities, in which armed forces are deployed and at least one of the parties to the conflict is a state government. The UCDP identifies four types of conflicts:

Interstate conflict is a conflict between two governments. The governments of the states must be the primary actors who formulated the incompatibilities. The mere presence of state actors on both sides of the conflict is not a sufficient criterion for the classification as an interstate conflict, since there can be also an intrastate conflict with foreign participation. It is the least problematic category that reflects the standard concept of armed conflicts within the traditionally viewed system of international relations. Still, it is a category that currently does not need to have totally clear boundaries and is often blended with the below hybrid form.

Intrastate conflict assumes that the primary actors are the government of the state and a non-state actor without the participation of other countries. This typology, none the less, does not address what will happen, if the conflict involves a non-state actor with its origin (location, headquarters, centre of operations) abroad. ${ }^{6}$ There are many cases that illustrate this, such as the initial activities of the Islamic state (established in Iraq) or armed formations of the Lebanese Hezbollah movement in the civil war in Syria. If such type of involvement was the only foreign participation in the conflict, according to this definition, it still, theoretically, accounts as an intrastate conflict.

Hybrid form is represented by an intrastate conflict with foreign involvement, again involving the government and a non-state actor at the primary level. At the same time, one or both primary actors receive direct military support from the government of another state. As with the intrastate conflict, this category is also currently affected by the ongoing transformations, as may be illustrated by the civil war in Syria. The quantity of external military support for the conflict parties is in many ways beyond the local actors' own capacities, thus, the intrastate nature is given solely by the geographical constraints of the conflict. Following many years of intense fighting activities, the Syrian government forces are so exhausted that Iranian land forces or Lebanese Hezbollah have significantly higher quantitative and qualitative representation in defending the interests of the former regime than the Syrian Arab Army itself. Similar situation exists in the air with the dominant presence of the Russian air contingent. However, the external

4 DE SPIGELAIRE, S., SWEIJS, T., ZHAO, T. Contours of Conflict in the $21^{\text {st }}$ Century, The Hague Centre for Strategic Studies, Rapport No $06 / 03 / 11$, p. 67. DYČKA, L. Typologie aktérů v konfliktech: Angolský prípad. Politologická revue, Issue 1/18/2012, pp. 73-93.

6 DYČKA, L. Aktéri surovinového konfliktu v Angole. Brno: FSS MU 2010, p. 17. 
support is no less significant in the case of the opposing formations, whether foreign jihadists and Iraqi Sunnis in the ranks of the Islamic State or other external elements in the ranks of the Syrian opposition or Kurdish formations. Practically all fighting parties are fundamentally dependent on external aid and even though the Syrian conflict cannot be labelled as a proxy war between the dominant external actors, it cannot be limited to a conflict of an intrastate nature either.

The UCDP also defines a non-state conflict. It refers to the use of armed forces by two actors, neither of which is a government of any state, if the conditions of organization of the actors and reaching 25 casualties of the conflict within one year are fulfilled. Even in this case the category can be considered somewhat problematic. In the conditions of failed states, none of the warring actors may be regarded as a state actor, or such situation can occur that in these conditions there are more warring actors, who still need not be in a direct conflict with an actor with certain, perhaps only externally granted, legitimacy. In the ongoing conflicts, e.g. in Libya or Somalia, we can identify one internationally recognized representative of the state power, but these representatives are far from controlling the most of the national territory and often have virtually no impact on other armed actors, albeit not being in the armed confrontation with some of them. In such conflicts, the differences between state and non-state actors are blurred and the question is whether thus defined typology is fully relevant to such cases.

The problem with this typology of conflicts is also in the question who can be considered a state actor and how to assess impartially the degree of their legitimacy. ${ }^{7}$ Even today there are several state entities whose legitimacy or international recognition are subject of controversy and completely different approaches. A potential armed conflict between Georgia and the separatist Abkhazia or South Ossetia could be classified both as an interstate or intrastate conflict, based only on the perspective. Similarly, a hypothetical armed conflict between Kosovo Albanians and Kosovo Serbs, limited to the geographic area of the Kosovo entity, could be interpreted as an intrastate or non-state conflict. A whole range of similar examples can be found. Even a non-state actor in the conflict can have the characteristics of a state actor, i.e. regular conventional military, government, defined territory, etc. It would be perhaps more appropriate to use the categories of quasi or semi state actors, such as the RSK (Republic of Serbian Krajina) in Croatia or the Kurdish autonomy in Iraq.

Similar to the UCDP, conflicts are classified by another institution respected in the academic community, namely the Heidelberg Institute for International Conflict Research. The methodology of the HIIK distinguishes between interstate, intrastate, and substate conflicts. Whereas interstate conflicts only involve internationally recognized state actors, intrastate conflicts involve both state actors and non-state actors. Sub-state conflicts occur solely among non-state actors. ${ }^{8}$

7 NYE, S. J., WELCH, A. D. Understanding Global Conflict and Cooperation: Intro to Theory and History Harlow: Pearson, 2014. ISBN 978-1-29202-318-2., p. 48.

8 Heidelberg Institute for International Conflict Research, Conflict Barometer 2016, No. 25, online edition, Heidelberg, 2017, http://www.hiik.de/en/konfliktbarometer/pdf/ConflictBarometer_2016.pdf 
However, some of the conflicts are difficult to classify using the applied typologies, they can change their basic parameters and it can be difficult to assess the incompatibility of the involved parties. For instance, the conflict in Kosovo between 1998-1999 can be labelled as an intrastate conflict in its first stage, in the second stage as an intrastate conflict with foreign involvement, and finally as interstate in the third stage, as we can also identify the incompatibility of primary state actors.

There are also intrastate conflicts which may not involve external aid, but in which the parameters of the conflict are determined by external actors without being described as primary or secondary ones. They can significantly influence the course and outcome of the conflict and therefore should not be excluded from the typologies. These actors can, for example, set up no-fly zones or the so-called safe zones, which limit one of the parties or prevent it entirely from achieving military superiority, thus indirectly prolonging the conflict (see e.g. the conflict in $\mathrm{BiH}$ ).

\section{CONFLICT TYPOLOGY BY INTENSITY}

Conflicts can be analysed and classified according to their intensity, or the intensity of armed violence, established primarily based on the number of the resulting number of casualties. Researchers M. Small and D. Singer, who developed the conceptualization and typology of war under the Correlates of War Project, put considerable emphasis on the quantitative criteria and tried to distinguish war from conflicts of another type with a lower intensity. According to these scholars, the threshold of 1,000 battle-related deaths caused by sustainable organized armed forces differentiates war from other types of conflict. ${ }^{9}$ This criterion is broadly accepted by the academic community; however, the threshold of 1,000 deaths was broadened to include civilian casualties. ${ }^{10}$ This criterion was adopted and used by a number of other authors and important research institutions, and it was further elaborated by the UCDP. ${ }^{11}$ The Uppsala Conflict Data Program introduces an empirical-quantitative analysis of conflicts and offers a deeper differentiation of conflict intensity.

There are three categories of armed conflicts: (1) minor armed conflict, which involves at least 25 battle-related deaths but less than 1,000 for the whole duration of the conflict; (2) intermediate armed conflict, in which the number of deaths counts more than 25 people and fewer than 1,000 per year, but more than 1,000 during the entire conflict; and (3) war, a conflict in which there are more than 1,000 deaths in one year. It

9 SINGER, J. D., SMALL, M. The Wages of War, 1816-1965: A Statistical Handbook. New York: John Wiley \& Sons Inc. 1972, p. 8.

10 SARKEES, M.R. The COW Typology of War: Defining and Categorizing Wars. The Correlates of War Project 2017, http://www.correlatesofwar.org/data-sets/COW-war/the-cow-typology-of-war-defining-andcategorizing-wars

11 LEVINGER, M. Conflict Analysis. Understanding Causes, Unlocking Solutions. Washington, DC: United States Institute of Peace 2013, p. 213. 
means that a conflict has to reach a certain magnitude before it is classified as "armed". It is measured in terms of a minimum of 25 battle-related deaths per year and per incompatibility. ${ }^{12}$

The number of casualties is considered as one of the indicators of the gravity and intensity of armed conflicts also by the HIIK, which uses differently set quantitative criteria. In its typology, the overall number of casualties in the conflict in a region-month is evaluated, comprising the number of deaths from violent measures or their direct consequences. Persons dying due to indirect effects, e.g. starvation or disease, are not counted. The thresholds employed here are 20 and 60 persons killed. ${ }^{13}$ However, the informative value of these indicators in practical terms is often complicated by the limited availability of credible data in the framework of the ongoing conflicts. The parties in the conflict are often interested in manipulating the actual numbers of losses, and there are considerable distortions in the published data, whether in order to maximize or minimize the numbers. The motives are mostly political or propaganda and a lot of false information may have quite a long life even after the end of the conflict. An example might be the information about 200 thousand of victims of the conflict in BiH that appeared already in the first months of its duration. In the post-war period, however, the number of confirmed victims was established as 96 thousand based on an extensive research of the UN. However, more than 20 years after the termination of the conflict, some academic texts still refer to the above exaggerated information. ${ }^{14}$

There is also the question of the relevance of similar quantification in present or future conflicts. The value of human life is not a universally applicable unit and can lead to significant distortions in the evaluation and analysis of the conflict. There are conflicts that fully meet the parameters of the conflicts of the highest levels based on the number of casualties, still, in relation to the local context they may be seen as less severe even by the actors themselves. The degree of sensitivity to own and overall human losses is important and for actors with different backgrounds it can be vastly different. Limited escalation of armed violence (whether temporally or geographically), for example in the form of border clashes, may result in a large number of casualties in some regions of the world, whether from the ranks of combatants or civilian population, still, from the point of view of state actors it may be a relatively insignificant confrontation defining their mutual position and hold on power. However, a quantitatively comparable incident occurring elsewhere could be interpreted as a large-scale military conflict. The sensitivity toward loss can, of course, significantly influence the course of the conflict or the behaviour of actors and be reflected in the evaluation of the conflict itself, whether by the participating actors or in the perception of the surroundings. The difference in sensitivity, of course, concerns mainly the actors themselves and their behaviour, none

12 The Uppsala Conflict Data Program, online edition, Uppsala, 2017, http://www.pcr.uu.se/research/ucdp/ definitions

13 Heidelberg Institute for International Conflict Research, Conflict Barometer 2016, online edition, Heidelberg, 2017, https://www.hiik.de/en/konfliktbarometer/pdf/ConflictBarometer_2016.pdf

14 STOJAROVÁ, V. Současné bezpečnostni hrozby západního Balkánu. Kritická analýza konceptu bezpečnosti Kodaňské školy. Brno: CDK 2007, p. 70. 
the less, in the framework of general typology it may lead to individual distortions of the conflict and its severity.

The loss of a few soldiers during the US intervention in Somalia led to a complete withdrawal of this world superpower from the original objectives, while incomparably greater losses occurring almost at the same time did not significantly affect the Russian effort to eliminate the Chechen separatism. During the 15 years of its deployment in Afghanistan, US armed forces lost 2400 persons of military personnel in the globally watched conflict, while a comparable amount of lost human lives was virtually the daily quota of the Second Congo War, uncovered by the media. In this context, the decade-long Mexican Drug War can also be mentioned, accounting for tens of thousands of victims, whereas it could be classified as an intrastate or non-state conflict of high intensity, however, outside the media attention and in the past also outside the UCDP's overview. The importance of the so-called hierarchy of death for the global media attention has already been described many times, but in relation to the analysis of the conflict it is not fully reflected. Critically evaluating these quantitative indicators, today's aim is not only to provide somewhat controversial assessment or a different perception of the value of human life. Technological progress already leads to dynamic implementation of robotic devices, which may significantly affect the appearance and operation of conflicts in this respect. Human losses may not be a fully reliable indicator of armed violence today. The so-called drone war, led by the US in certain regions, completely minimises their own natural human losses, does not require their own long-term military presence in the area of deployment and often takes place without any authorisation from the local government authorities, though they may be US allies. Such conflicts make the US a specific actor, difficult to be included in the existing typologies. The process of robotisation, however, can prospectively largely suppress the human element in direct combat activities and thus render the quantitative indicator based on the number of human losses less relevant. ${ }^{15}$ Already today, such scenarios are evaluated as real in the medium term and can lead to a massive military confrontation of technologically advanced state actors, in which the numbers of human losses could be minimal. Such conflicts would primarily take place between the robotic armed systems, whether drones in the air or sea and land weapon systems without human crew, and would be terminated in the case of proven superiority of one party or completed upon the exhaustion of available resources without any significant deployment of human component in the war operations, thus eliminating potential human losses.

\section{CONCLUSIONS}

There is no generally accepted typology and for research or categorisation of armed conflicts there is a whole range of other approaches. It is possible to choose based on personal preferences or the focus of a specific research. In the period of the second half

15 STOJAR, R. The Robotisation of Armed Conflict, 4th International Multidisciplinary Scientific Conference SGEM, Book 1, Volume 2, p. 275. 
of the $20^{\text {th }}$ century, when the academic community started to research conflicts in more depth, most of the conflicts were associated with the collapse of the colonial system and the subsequent wars for local or regional dominance (in Africa and Asia), or a little later, with the breakdown of the multinational state units that, owing to internal causes, were not able to adapt to the democratisation processes, following the collapse of the bipolar world (in the eastern European area). For the $21^{\text {st }}$ century conflicts, the typologies based primarily on the preceding period are no longer appropriate as they do not fully reflect both the social and the technological changes and to a certain extent also the developments in international relations. The currently ongoing intense conflicts, such as the civil war in Syria, are often taking place against the background of larger and more complex events, which must be also taken into account in the analysis and classification. Armed conflicts will not certainly be a thing of the past and will continue to provide space for research. Newly discussed forms of conflict, removing the borders between war and peace, so-called hybrid wars, can bring additional impetus for new criteria or indicators and become reflected in the new approaches and typologies.

Author: $\quad$ Richard Stojar, Ph.D., born in 1970. Graduate from the Faculty of Arts, Masaryk University in Brno, where, alongside the University of Defence, he lectures on the topics of security policy and international relationships. In 2005-2008 he was a representative of the Czech Republic in Regional Arms Control Verification and Implementation Assistance Centre -SE Europe. Since 2002 he works at University of Defence in Brno, currently at Centre for Security and Military Strategic Studies. Member of the Editorial Board of the journals Defence and Strategy, Strategic Impact and the Rexter. He is specialised in the problem of security threats and risks, armed conflicts in the post-bipolar world, security dimension of the European integration and development of the security environment, especially in the South-Eastern European region.

How to cite:

STOJAR, Richard. Typology and Analysis of Armed Conflicts. Vojenské rozhledy. 2017, 26 (5), 83-92. ISSN 1210-3292 (print), 2336-2995 (on-line). Available at: www.vojenskerozhledy.cz 
Information

\title{
The Future of Military Cooperation in Central Europe
}

\section{Budoucnost vojenské spolupráce ve střední Evropě}

\author{
Gunther Hauser
}

Abstract: The current security threats cannot be countered by any single country, but only through comprehensive cooperation within reliable security partnerships. Thus, regional tailored military cooperation has gained more importance than ever before in order to tackle various threats and challenges and to strengthen crisis management capabilities. Therefore, Austria launched the Central European Defence Cooperation (CEDC) in 2010 to foster regional security cooperation and to promote modernisation of military resources. Two years later, Austria co-founded the EU Mountain Training Initiative which closely coordinates training and education with the NATO Mountain Warfare Centre of Excellence in Slovenia. This paper aims at analysing and discussing current initiatives and possible ways of improving Central European security cooperation between NATO member states and Austria.

Abstrakt: Současným bezpečnostním hrozbám nemůže čelit žádná země osamoceně, ale pouze prostřednictvím komplexní spolupráce $v$ rámci spolehlivých bezpečnostních partnerství. Díky tomu získala vojenská spolupráce založená na regionální bázi větší důležitost než kdykoli předtím, nebot' jen tak je možné vypořádávat se s různými hrozbami a výzvami a posílit tak schopnosti krizového řízení. V roce 2010 proto Rakousko zahájilo Středoevropskou obrannou spolupráci (CEDC), aby tak podpořilo regionální bezpečnostní spolupráci a podpořilo modernizaci vojenských kapacit. O dva roky později Rakousko spoluzaložilo Iniciativu horského tréningu EU, která úzce koordinuje výcvik a vzdělávání ve spolupráci se slovinským NATO Mountain Warfare Centre of Excellence. Cílem tohoto článku je analyzovat a diskutovat současné iniciativy a možné způsoby zlepšování středoevropské bezpečnostní spolupráce mezi členskými státy NATO a Rakouskem.

Key words: Central European Defence Cooperation; Mountain Training Initiative; Hybrid Warfare; Cyber Threats; Crisis Management.

Klíčová slova: Obranná spolupráce ve střední Evropě; Iniciativa horského tréninku; hybridní válčení; kybernetické hrozby; krizový management. 


\section{INTRODUCTION}

Coordinated military cooperation has gained more importance than ever before in order to tackle various threats and challenges: "If you look at the multiplication of potential threats many countries face - the thinking now about Russia, the terror threat - and general world instability ... defence is really no longer down the agenda." ${ }^{1}$ The need to reflect how to deter, respond and protect against threats such as terrorism, large-scale cyber-attacks, the proliferation of weapons of mass destruction and hybrid threats, has never been so critical. However, a closer cooperation between European nations is more imperative than ever before - at a time when Europe should move towards closer cooperation in the light of doubts about U.S. President Donald Trump's commitment to NATO:2 "President Trump's focus on NATO's usefulness and efficacy has caused European allies to no longer assume the transatlantic alliance can be taken for granted." ${ }^{3}$ In July 2016, during the U.S. election campaign, Trump said that if Russia attacked Baltic states, he would decide whether to come to their aid only after reviewing whether those nations "have fulfilled their obligations to us." ${ }^{4}$ Five years earlier, then-U.S. defence secretary Robert Gates told that NATO had a "dim if not dismal future" and warned of possible "military irrelevance". Gates added that there was "dwindling appetite" in the US to keep supporting the organisation."

The Ukraine crisis has been a game changer for European security and a wake-up call for European members of the EU and NATO, highlighting the growing strategic challenge of Russia to the institutions and security of Euro Atlantic community. According to retired Admiral James Stavridis, who served both as a commander of NATO and U.S. European Command, Russia conducts military operations with "cleverness": "Some have called this hybrid warfare. It's a mix of special forces; information warfare; cyber ... and this element of surprise, building real ambiguity into their maneuvers." ${ }^{\prime \prime}$ Thus, hybrid warfare relies on a combination of non-traditional tools plus the insertion of irregular forces and/or commandos, all executed below the threshold of a conventional military invasion across borders. Hybrid warfare is designed to create a chaotic environment (by use of deception, coercion and ethnic unrest).

1 Alexandra Ashbourne-Walmsley, assoicate fellow of the Royal United Services Institute, in: Jon Henley, Women copmmand EU's defence stronghold, The Guardian Weekly, 26.05.2017, p. 7.

2 Ebenda.

3 Anders Fogh Rasmussen, Trump has shown the transatlantic relationship cannot be taken for granted, European Leadership Network, Brussels 2017, p. 3, http://www.europeanleadershipnetwork.org/ trump-has-shown-the-transatlantic-relationship-cannot-be-taken-for-granted (accessed on 29 May 2017, 12:35 hours).

4 David E. Sanger and Maggie Haberman, Trump casts doubt over U.S. pledges to its allies, International New York Times, July 22,2016, pp. 1 and 4, p. 4.

5 Geoff Dyer, Washington can focus on Asia only with a robust NATO, Financial Times, May 22, 2012, p. 2.

6 Jen Judson and Aaron Mehta, US Army Pivots to Europe As Russian Threat Grows, Defense News, February 15, 2016, p. 8. 
Cyber threats and attacks will continue to become more common, sophisticated, and potentially damaging. Cyber-attacks can reach a threshold that threatens national and Euro-Atlantic prosperity, security and stability. Their impact could be as harmful to modern societies as a conventional attack. The current threats to our security cannot be countered by any single country, but only through wide international co-operation and collective effort within international reliable security partnerships. This paper aims at analysing and discussing possible ways of deepening Central European security cooperation in order to face common risks and threats.

\section{EUROPEAN SECURITY COOPERATION - WAYS AND CHALLENGES}

The efficiency of security and military co-operation depends on the political will and interests of the participating states as well as the political framework conditions that determine the depth of such co-operation.

In 2014, a joint statement was adopted to identify privileged areas of cooperation between EU and NATO in Warsaw. This includes countering hybrid and cyber threats, supporting new partners in defence capacity, broadening and adapting "operational cooperation including at sea, and on migration, through increased sharing of maritime situational awareness", developing "coherent, complementary and interoperable defence capabilities of EU Member States and NATO Allies, as well as multilateral projects", and facilitating "a stronger defence industry and greater defence research and industrial cooperation within Europe and across the Atlantic". 7

The hybridization of security "establishes a complex system of international state, non-state and civic actors, who interact and compete for power and resources and determine patterns of security." 8 In "such contemporary hybrid security the new quality also includes peacekeeping, crisis management and peace support in the most generic meaning." ${ }^{1}$ However, peacekeeping "too has to hybridize sooner or later and integrate itself into the logical circle: hybrid war - hybrid peace support - hybrid peace. Hybrid peace operation is carried out by joining different types and means of peace support. We can join different types of operations like military, police, civilian, humanitarian, etc. or share different goals like ceasefire, separation of force, peace enforcement, security sector reform, build-up of civic society, good governance, respect of human rights, etc."10

7 North Atlantic Treaty Organization, Joint declaration by the President of the European Council, the President of the European Commission, and the Secretary General of the North Atlantic Treaty Organization, Press Release (2016) 119, Issued on 08 Jul. 2016.

8 Mirko Cigler, Hybrid Peacekeeping, in: Thomas Achleitner and Günther Greindl, New Challenges in Contemporary Peace Operations, October 21st-23rd, 2015, National Defence Academy, Blue Helmet Forum Austria 2015. An Initiative of the Association of Austrian Peacekeepers, Vienna 2015, pp. 53-59, p. 55.

9 Ibid., p. 57.

10 lbid., pp. 57-58. 
This, hybridity can also be considered "as a relationship between traditional and non-traditional understandings of the role and the extend of peacekeeping in the whole conflict spectrum from early warning and conflict prevention to conflict management, limitation, resolution and post conflict rehabilitation."11

Security and military cooperation remains of utmost importance, also among Central European states in this context.

In order to strengthen European strategic autonomy, Central European forces should achieve interoperability with each other, by contributing national combat units, anchored in multinational corps structures and multinational command, logistics, maintenance, and training. Targeted Central European forces coordination can foster and enhance EU capabilities in these various fields of cooperation.

European leaders should be convinced that the European Union needs a common foreign policy and the military instruments to support it. Member states will remain sovereign in their defence decisions also in the future. EU Common Security and Defence Cooperation will be continued to be focused on crisis management. To achieve goals defined in the 2016 European Global Strategy (EGS), enhanced cooperation between Member States should be explored and might lead to more structured form of cooperation, making full use of the Lisbon Treaty's potential. According to the EGS,

"Member States must channel a sufficient level of expenditure of defence, make the most efficient use of resources, and meet the collective commitment of 20 percent of defence budget spending devoted to the procurement of equipment and Research and Technology."12

Furthermore, capabilities "should be developed with maximum interoperability and commonality, and be made available where possible in support of EU, NATO and UN and other multinational efforts." 13

In the Lisbon Treaty, there are various possibilities to enhance cooperation in the fields of Article 43 EU Treaty "Tasks", particularly in the field of humanitarian and rescue tasks, military advice and assistance tasks, conflict prevention and peace-keeping tasks, tasks of combat forces in crisis management, including peace-making and post-conflict stabilisation. All these tasks may contribute to the fight against terrorism, including by supporting third countries in combating terrorism in their territories. ${ }^{14}$

According to Article 44 EU Treaty "the Council may entrust the implementation of a task to a group of Member States which are willing and have the necessary capability for such a task." ${ }^{15}$ According to Article 46 EU Treaty, those member states which wish to participate in the permanent structured cooperation, which fulfil the criteria and have

11 Ibid., p. 58.

12 European Union, Shared Vision, Common Action: A Stronger Europe. A Global Strategy for the European Union's Foreign and Security Policy, June 2016, p. 44.

13 lbid., pp. 44-45.

14 European Union, Consolidated Version of the Treaty on European Union, Official Journal of the European Union C115, 9 May 2008, p. 39.

15 Ibid. 
made more binding commitments to one another in this area with a view to the most demanding missions shall establish permanent structured cooperation, shall notify their intention to the Council and to the High Representative of the Union for Foreign Affairs and Security Policy. ${ }^{16}$

On the development of capabilities, the Foreign Affairs Council of 18 May 2015 noted in particular progress in the four key Pooling and Sharing projects: air-to-air refuelling; remotely piloted aircraft systems (drones), governmental satellite communications, and cyber defence carried out under the auspices of the European Defence Agency "and encouraged further efforts and incentives for the development of cooperative capability projects."17

Indeed, the Pooling and Sharing "aspect of a Europe-wide coordination and mutual calibration of defence planning and military procurement [...] has taken a back seat or was simply "ignored by the ministries and the bureaucracies'" as the Foreign Affairs Council (Defense Ministers format) criticised in September 2015. ${ }^{18}$ Austria participates in three of the four Pooling and Sharing pilot projects (the exception being air-to-air refuelling) "and of several smaller ones. Nevertheless, the challenge to adequately participate persists."19

\section{AUSTRIAN CENTRAL EUROPEAN MILITARY COOPERATION INITIATIVES}

Austria will continue its cooperation with NATO, as also pledged in the 2013 National Security Strategy, in crisis management, in cooperative security endeavours, and in participation in trainings and exercises "to uphold the interoperability and the relevant military standards of the armed forces." 20 To KFOR mission, Austria is, with its nearly 500 -strong contingent in Kosovo, the fourth largest troop contributor. In order to increase interoperability, military cooperation with Central European nations remains essential for Austria on various fields.

Thus, in 2010, Austria launched the Central European Defence Cooperation (CEDC) - together with the Czech Republic, Hungary, Slovakia, Croatia and Slovenia. It "is a security policy coordination forum." 21 Poland has observer status. CEDC fosters "regional

16 Ibid., pp. 40-41.

17 Gerhard Jandl, Crisis Management Challenges for Austria, in: Thomas Achleitner and Günther Greindl, New Challenges in Contemporary Peace Operations, October 21st-23rd, 2015, National Defence Academy, Blue Helmet Forum Austria 2015. An Initiative of the Association of Austrian Peacekeepers, Vienna 2015, pp. 97-115, pp. 99-100.

18 Ibid., p. 100

19 Ibid.

20 Ibid., p. 108

21 Federal Minister for Defence and Sports, Central European Defence Cooperation (CEDC), Vienna 2016, p. 1. 
military cooperation in selected areas through shared military projects."22 The shared field of interest focuses to the sustained stabilisation of the Western Balkans.

A cooperation by which security challenges are collectively met, for example Cross-Border Disaster Relief, CEDC enables a regional military partnership in the sense of Pooling and Sharing, which promotes armed forces modernisation through shared experience and synergies. Croatia there is the framework nation for conducting training activities for Special Forces: exercises have been conducted by the Croatian and Austrian Special Operation Forces. Hungary is the framework nation for conducting training activities for Forward Air Controllers, Air Traffic Controllers and in the field of Counter-Improvised Explosive Devices (IEDs). Training courses are vital to improve soldier's protection against IEDs. ${ }^{23}$

Reacting to the refugee and migration crisis in Europe, the Central European Defence Cooperation under the Austrian presidency adopted three central goals in 2016: the launch of a joint initiative with respect to the security of the external borders, the closure of the Balkan route and the launch of return measures. These goals have been already nearly achieved.

In 2012 Austria took the leading role with regard to the EU Pooling and Sharing - and co-founded the Mountain Training Initiative. After years of cooperation between Austrian and German mountain troops, the readiness of mountain troops is further developed with other European partners by means of this Austro-German initiative. Nine nations are part of this initiative, the permanent members being Austria, Belgium, Bulgaria, Croatia, Germany, the Netherlands, Poland, Slovenia and Sweden. Close coordination was established with the NATO Centre of Excellence (CoE) for Mountain Warfare in Slovenia in order to exchange experience, especially within the "Lessons-Learned" process and in order to avoid duplication. The NATO CoE focuses on doctrines and rules, the EU initiative on concrete educational and training cooperation. ${ }^{24}$

\section{DEEPENING CENTRAL EUROPEAN COOPERATION - CAPABILITY MANAGEMENT}

Central European nations can create a pool of coordination in order to increase capabilities in peace support operations within the UN, NATO and EU framework relating to the following tasks: ${ }^{25}$

22 Ibid.

23 Ibid., p. 3.

24 Peter Grünwald, 'Mountain Training Initiative'. In: Der Offizier. Zeitschrift der Österreichischen Offiziersgesellschaft, no. 1 (2016): pp. 24-27, p. 24.

25 Blue Helmet Forum Austria 2015 - Summary of Essential Points, in: Thomas Achleitner and Günther Greindl, New Challenges in Contemporary Peace Operations, October 21st-23rd, 2015, National Defence Academy, Blue Helmet Forum Austria 2015. An Initiative of the Association of Austrian Peacekeepers, Vienna 2015, p. 11. 
- The protection of the civilian population, the safeguarding of cultural assets and preventive deployment;

- Training and education: Peace operations will continue to be focused on the Middle East and Africa, directly affecting European security. Therefore, cooperation with regional partners such as the EU, NATO, OSCE and African Union will continue to be intensified. Peace operations get riskier due to uncontrolled armed elements and usually chaotic conditions in operational areas. Troops participating in peace operations must continuously be well trained and well equipped in order to cope with robust operations;

- Reconnaissance, engineers, air transport and logistics are key capabilities of Austrian forces, thus Austria is in a good position to contribute towards covering the capabilities required;

- Interoperability is the key to mission success in particular in a multinational environment. NATO is considered the recognised 'standardisation agency' for European and also for international forces, and here the PfP network plays a significant role. NATO's PfP for example offers many tools to achieve interoperability like the Planning and Review Process or the Operational Capabilities Concept Evaluation and Feedback program..

- A list of the elements for which there is always the greatest need in peace operations shows as follows: Intelligence, surveillance and reconnaissance (including satellites, drones (UAVs), electronic reconnaissance (SIGINT) and human intelligence (HUMINT) 26

- Capabilities for command and control (C2).

- Rapidly available intervention forces (Rapid Reaction Forces) - including the EU Battle Groups;

- Medical evacuation capacities (CESAVAC/MEDEVAC helicopters and fixed-wing aircraft like the Pilatus Porter);

- Tactical transport aircraft (especially helicopters);

- Tactical air support (close air support);

- Robust infantry;

- Military and police instructors and trainers (train-advise-assist);

- Strategic planners on civilian, police and military levels;

- Experts in security sector reform and justice;

- Civilian and military observers;

- Formed police units, i.e. paramilitary deployable and trained police units along the lines of constabulary or carabinieri or military police;

- Specialised police in terms of forensics;

- Experts in bomb disposal (Explosive Ordnance Disposal, EOD) and in combating improvised booby-traps (Counter-Improvised Explosive Devices, C-IED). ${ }^{27}$

26 Current capability-based requirements, in: Thomas Achleitner and Günther Greindl, New Challenges in Contemporary Peace Operations, October 21st-23rd, 2015, National Defence Academy, Blue Helmet Forum Austria 2015. An Initiative of the Association of Austrian Peacekeepers, Vienna 2015, p. 23.

27 Ibid., pp. 23-24. 


\section{CONCLUSIONS}

Austria covers some of the fields listed here to provide urgently needed personnel or specialised equipment and therefore is able to contribute to Central European security cooperation and provide niche capabilities. Furthermore, regional tailored cooperation could strengthen crisis management capabilities in the following tasks and objectives:

- Rapid response;

- Support to the African peace and security architecture;

- Cooperation in the domain of rule of law and Security Sector Reform, including in the area of Defence Sector Reform; and

- cooperation in support and logistics.

The UN has, at several occasion, expressed interests in having the EU Battlegroups deployed in supporting UN mandates in order to prevent or curtail conflict and to protect civilians. More enhanced military cooperation and coordination can provide - from an Austrian standpoint - the necessary assets to conduct more effective peace support management. Our common goal in Central Europe remains to stabilise the Western Balkans, to train soldiers from the region, and to further integrate this region into the EU. Enhanced military cooperation in Central Europe will continue to be necessary to tackle common man-made and natural threats as well as challenges in the region and out of area. Fields of cooperation are manifold, particularly also for and among Central European nations. Coordinated and effective military cooperation has never been that vital for the future of Central Europe and the European Union itself in order to keep our societies safe and secure.

Author: $\quad$ Gunther Hauser, M.A. (political science/international law, University of Innsbruck), Ph.D. (political science/constitutional law, University of Salzburg) is Head of the Section International Security, senior researcher and lecturer at the Institute for Strategy and Security Policy (ISS), National Defense Academy, Vienna. In 2006, Dr. Hauser began lecturing at the Center for European Integration at Danube University Krems and was appointed Vice President of the Scientific Forum on International Security at the German Armed Forces Command and Staff College in Hamburg. Since 2014, he has held the title of honorary professor and member of the scientific board of the Department for Business Law and European Integration at Danube University Krems.

\section{How to cite:}

HAUSER, Gunther. The Future of Military Cooperation in Central Europe. Vojenské rozhledy. 2017, 26 (5), 93-100. ISSN 1210-3292 (print), 2336-2995 (on-line). Available at: www.vojenskerozhledy.cz 
Information

\section{The Future Security Environment: An Emerging View Budoucí bezpečnostní prostředí: Nový pohled}

\section{Aaron Bazin}

Abstract: The future security environment through 2035 and beyond will likely be increasingly complex and both present challenges and offer opportunities to NATO military forces. Analysis of the future security environment indicates that forces will likely face challenges that could unfold in an exponentially accelerated and increasingly complex fashion. As trends converge in the future, there are twelve likely instability situations that could reach a threshold requiring the Alliance's use of military forces. However, there are also many opportunities that NATO military forces could seize in the future, including building and strengthening relationships, addressing emerging challenges, capitalising on innovative technology and ideas to maintain the military edge, and understanding and influencing the human aspects of conflict.

Abstrakt: Budoucí bezpečnostní prostředí do roku 2035 a poté bude pravděpodobně stále složitější a bude pro vojenské síly NATO přinášet výzvy i příležitosti. Z analýzy budoucího bezpečnostního prostředí vyplývá, že ozbrojené síly budou pravděpodobně čelit výzvám, které se mohou rozvíjet s exponenciálním zrychlením a stále složitějším způsobem. Na základě budoucího směřování trendů Ize identifikovat dvanáct pravděpodobných př́padů nestability, které by mohly dosáhnout mezí vyžadujících použití vojenských sil aliance. Existuje však také mnoho příležitostí, které mohou ozbrojené síly NATO v budoucnosti využít, například budování a posilování vztahů, řešení nově vznikajících problémů, využití inovativních technologií a myšlenek k zachování vojenské výhody a porozumění lidských aspektů konfliktu s možností je ovlivnit.

Keywords: NATO; Future Security Environment; Framework for Future Alliance Operations; Strategy.

Klíčová slova: NATO; budoucí bezpečnostní prostředí; rámec budoucích aliančních operací; strategie. 


\section{THE FUTURE SECURITY ENVIRONMENT: AN EMERGING VIEW}

Today, NATO military forces face a challenge in that they must adapt, evolve and innovate to constantly address an ambiguous, complex, and rapidly changing security environment. To help inform the discussion options on how best to change, the NATO Long-term Military Transformation Programme seeks to identify the abilities of the future Alliance's pool of forces to meet the potential demands of the security environment today, through the near future, into 2035 and beyond. This paper describes a summary of working-level discussions and workshops held between January 2016 and April 2017 and sponsored by Allied Command Transformation as an emerging view of the challenges and opportunities NATO may have in the future as a baseline for organizational adaptation and innovation.

\section{FUTURE CHALLENGES}

In the study of war and armed conflict, there are some factors that change over time and some that remain the same. By its nature, war has always been a contest of wills driven by fear, honour and interest.War remains a phenomenon where three key factors interact: (1) primordial violence, hatred, and enmity; (2) the play of chance, fog, and friction, and (3) its use for political purposes.

However, as evidenced by current threats involving non-state actors, each instance of armed conflict is different from the last as the character of conflict changes over time. Factors such as technological advances, new operating concepts, changes in the security environment, and shifts in the geopolitical landscape will greatly influence the security environment of the future.

Since its founding, NATO has seen many shifts in the character of armed conflict. Although it is impossible to determine with absolute certainty what conflict will be like in the future, analysis of trends indicate that conflict in the future may be characterised by:

a) An increasing pace of the emergence and escalation of armed conflict.

b) Greater complexity of armed conflict where the dense linkages could result in cascading instability, and gray zones blurring the lines between military and non-military aspects of conflict.

c) Increased interconnectivity across the operating environment and the domains of warfare (air, land, sea, cyber, and space) and strategic communications.

d) A compression of the traditional levels of war where strategic, operational, and tactical events become difficult to differentiate.

e) Rapidly emerging technologies in areas such as cyber, autonomous systems, robotics, hypersonic weapons, digital data, artificial intelligence, communication, surveillance, electronic warfare. 
f) Increased likelihood of human enhancement through mechanical and biological means to improve military performance and the increasing importance of the human-machine interface.

g) Over time, the use of automated systems in warfare may increase and eventually may not directly involve humans in the decision cycle.

h) Smaller numbers of forces may fight over greater distances.

i) New classes of weapons of mass destruction/effect may emerge.

j) Increased numbers of sensors and the ubiquitous "internet of things" could influence operational security and increase the impact of social media on the battlefield.

k) An increase in the likelihood of armed conflict involving global commons, space, densely populated areas and subterranean areas.

I) The widely accessible and cheaper technologies are increasing the role of individuals, giving separate persons or groups the ability to produce uncontrolled and hard to predict effects.

$\mathrm{m})$ Increased access to knowledge could enhance and speed up the emergence and mobility of threats. This will likely include an increase in the use of innovative ways and means to exploit the weaponization of information activities to influence populations alone or in support of the armed conflict.

n) Increasing overlap between criminal activity and war/armed conflict.

Instability is a state of likely change. Not all instabilities in the security environment will result in a need and decision by the Alliance to employ military forces. Therefore, to focus on the specific operational impacts on NATO's military forces in the future, it is critical to clearly define and differentiate between instability drivers and instability situations. Instability drivers are defined as any conditions, events, or circumstances that increase the tendency for the security environment to be unpredictable, changeable, or erratic. Some instability drivers represent visible trends, others are slow emerging, underlying conditions that lead to unstable situations progressively over time. Others may act as catalysts that quickly change the security environment. For example, climate change, mass migration, and competition for resources may cause instability, as might differences in beliefs, value systems, and disruptive technologies. Disintegrating political, economic, rule of law, social systems and increasing population density could further complicate the security environment. Arguably, the greatest drivers of instability are the activities of hostile state and non-state actors. Such activities span a wide range, from isolated terrorist attacks, continued nuclear proliferation to the escalatory use of force. 


\section{INSTABILITY SITUATIONS}

- WMD/E Use

- Conventional War

- Escalatory Use of Force

- Hybrid War

- Unconventional War

- Global Commons Disruption

- Critical Infrastructure Attack

- Cyberattack

- Governance Challenges

- Endangerment of Civilian Populations

- Pandemic Disease

- Natural/Man-made

Figure 1: Instability Situations

Instability situations are defined as generic descriptions of possible future events of critical significance that could reach the threshold requiring the Alliance's use of military forces. ${ }^{1}$ Instability situations are not mutually exclusive and could occur in isolation or at the same time as others, resulting in a compounded effect, or hyper-instability. In the future, a wide range of instability situations may exist, including:

a) Weapons of Mass Destruction/Effect (WMD/E) Use: Hostile state and non-state actors could seek access to and use WMD/Es to cause widespread devastation and loss of life against targets such as political leadership, population concentrations, the global financial system, or locations of symbolic importance. ${ }^{2}$ This could include Chemical, Biological, Radiological, or Nuclear (CBRN) weapons or weapons of mass destruction based on new technologies.

b) Conventional War: State-on-state war between conventional forces will remain within the realm of the possible. This could include two or more states in an open confrontation where the forces on each side are well-defined and fight using weapons that primarily target the opponent's military. ${ }^{3}$

1 NATO-ACT, FFAO Bydgoszcz, Poland Conference Report 2016, http://www.act.nato.int/futures-ws-5, (November 2, 2016).

2 UN, "Weapons of Mass Destruction: Threats and Responses," http://www.un.org/ sustainabledevelopment/blog/2015/01/weapons-of-mass-destruction-threats-and-responses/, (November 2, 2016); NATO, AAP-6 Edition 2015, https://nso.nato.int/nso/sPublic/ap/aap6/AAP-6.pdf, (November 2, 2016).

3 David Barno and Nora Bensahel, "The Irrelevance of Traditional Warfare?" War on the Rocks, http:// warontherocks.com/2015/01/the-irrelevance-of-traditional-warfare/, (November 2, 2016). 
c) Escalatory Use of Force: Hostile actors may use threats or force increasingly over time to destabilise the security environment. This could lead to a strategic miscalculation or increase the likelihood of a wider conflict. ${ }^{4}$

d) Hybrid War: Hostile state actors will likely use a combination of conventional and unconventional means to avoid being held directly accountable for their actions while retaining the option to employ conventional forces, if directly threatened. One of the major characteristics of hybrid warfare is that it often aims to leverage all elements of power while limiting the conflict below the threshold of a conventional war, thus complicating the timely and effective use of rigid collective defence mechanisms. 5

e) Unconventional War: Hostile state and non-state actors may conduct military activities through or with underground, auxiliary or guerrilla forces to enable a resistance movement or insurgency to coerce, disrupt or overthrow a government or occupying power. ${ }^{6}$ In unconventional conflicts the use of propaganda could be utilized in an attempt to influence populations. In the future, terrorism is one of the widely used tactics that adversaries may use to pursue unconventional war. Hostile non-state actors may unlawfully use or threaten the use of force and violence against individuals or property at an increased scale, scope or duration in an attempt to coerce or intimidate governments or societies to achieve political, religious or ideological objectives. Terrorism can be used to create fear or terror in an attempt to gain control over the population. Additionally, hostile states will likely continue to use proxies that employ terrorism to further their own interests. ${ }^{7}$

f) Global Commons Disruption: Hostile actors may directly challenge international laws and norms in the global commons through threat or use of force. ${ }^{8}$ Increased competition for resources and commercialisation of space may lead hostile actors to directly challenge international treaties in new ways. Additionally, space disruption could be executed by kinetic or non-kinetic means, such as direct attack, jamming or cyberattacks. ${ }^{9}$

g) Critical Infrastructure Attack: Some physical and virtual infrastructure nodes and installations remain essential to the enduring interests of the Alliance (e.g., energy

4 ICRC, Violence and the Use of Force, https://www.icrc.org/eng/assets/files/other/icrc_002_0943.pdf, (November 2, 2016).

5 NATO, International Staff Memo, IMSM-0043-2016, (January 15, 2016).

6 NATO, AAP-6 Edition 2015, https://nso.nato.int/nso/sPublic/ap/aap6/AAP-6.pdf, (November 2, 2016).

7 Melissa Clarke, "Globally, Terrorism is on the Rise," ABC News, http://www.abc.net.au/news/201511-17/global-terrorism-index-increase/6947200_(November 2, 2016).; NATO, AAP-6 Edition 2015, MC472/1 "Military Committee Concept on CT", endorsed by MC and approved by NAC, December 2015) https://nso.nato.int/nso/sPublic/ap/aap6/AAP-6.pdf, (November 2, 2016), Institute for Economics and Peace, Global Terrorism Index 2015, November 2015, http://economicsandpeace.org/wp-content/ uploads/2015/11/2015-Global-Terrorism-Index-Report.pdf; NATO, PO(2015)0045, (November 2, 2016).

8 Gerald Stang, Global Commons: Between Cooperation and Competition, http://www.iss.europa.eu/ uploads/media/Brief_17.pdf, (November 2, 2016).

9 Lee Billings, "War in Space May Be Closer than Ever," Scientific American, https://www. scientificamerican.com/article/war-in-space-may-be-closer-than-ever/, (November 2, 2016). 
hubs, port facilities, etc.). Hostile actors could attack these nodes in an attempt to disrupt vital societal functions and global stability. ${ }^{10}$ This could also include an attack to deny the electromagnetic spectrum, position navigation and timing, radar, and other key systems. Such attacks can occur as physical attacks or in the form of cyber-attacks.

h) Cyberattack: Hostile actors could conduct a cyberattack of significant scale, scope or duration to disrupt, deny, degrade, modify, steal, or destroy information resulting in a large physical, emotional or financial impact. ${ }^{11}$ Hostile actors could use cyberattacks in isolation or in support of conventional, hybrid, or unconventional approaches.

i) Governance Challenges: Some governments may fail to provide administration and basic functions that could threaten internal and external security and destabilise the security environment. Furthermore, ungoverned spaces may exist where there is no legitimate rule of law resulting in a security vacuum and increasing the chance of an armed conflict. Additionally, the future migration and population flows could contribute to the emergence of governance challenges.

j) Endangerment of Civilian Populations: There is a potential for hostile actors to conduct large-scale acts of violence directed against civilian populations. These events could include mob violence, post-conflict revenge, insurgency, predatory violence, communal conflict, government repression, ethnic cleansing, destruction of cultural property, and genocide. ${ }^{12}$

k) Pandemic Disease: There is a possibility of an outbreak of a disease that occurs over a wide geographic area and affects an exceptionally large proportion of the population exceeding response capacity. ${ }^{13}$

I) Natural/Man-Made Disaster: There is a possibility of a sudden large-scale man-made or natural event that could result in serious damage, widespread death, and injury that exceeds response capacity. These events could occur as a culmination of several smaller individual disasters in a way that may have an effect similar to a large-scale disaster. ${ }^{14}$

10 Sarah Kuranda, "Experts: Recent Critical Infrastructure Attacks a Sign of Major Security Challenges Coming in 2016," CRN, http://www.crn.com/news/security/300079278/experts-recent-criticalinfrastructure-attacks-a-sign-of-major-security-challenges-coming-in-2016.htm, (November 2, 2016).

11 Jason Healy, The Five Futures of Cyber Conflict, http://journal.georgetown.edu/wp-content/ uploads/2015/07/110_gj124_Healey-CYBER-20111.pdf, (November 2, 2016).

12 Stian Kjeksrud, Alexander Beadle, and Petter Lindqvist, Protecting Civilians from Violence, https:// www.ffi.no/no/Publikasjoner/Documents/Protecting-Civilians-from-Violence.pdf, (November 2, 2016). NATO Policy for the Protection of civilians http://www.nato.int/cps/en/natohq/official_texts_133945. htm?selectedLocale=en (July 9, 2016)

13 Regina Parker, "Prevent Disease to Prevent War," The Strategy Bridge, http://www.thestrategybridge. com/the-bridge/2016/10/6/prevent-disease-to-prevent-war ${ }_{L}$ (November 2, 2016).

14 Peter Baxter, "Catastrophes - Natural and Manmade Disasters," Conflict and Catastrophe Medicine, http://link.springer.com/chapter/10.1007\%2F978-1-4471-0215-1_3_(November 2, 2016). 


\section{FUTURE OPPORTUNITIES}

Despite the many challenges anticipated in the future security environment, there are many opportunities that NATO Forces could seize upon to improve the security environment. ${ }^{15}$ Innovation and technological changes during this time period will offer military advantages that NATO forces or adversaries could capitalise on. Innovation is not only the adoption of new technologies but could include the combination of old technologies in novel ways. In this period, developments are likely to be the greatest in five broad areas, or BRINE: (1) biology, biotechnology and medicine; (2) robotics, artificial intelligence, new smart weapons, and human enhancement; (3) Information and Communication Technology (ICT), surveillance and cognitive science; (4) nanotechnology and advanced materials; and (5) energy technology. These developments could have an impact on organisational structures, culture, and processes. ${ }^{16}$

Although states will continue to develop new technologies, in many areas, the greatest advances will likely come from civilian entities. As such, relationships with academia and industry may become more critical to maintain the military advantage. Additionally, the Alliance has an opportunity to harness the creative thinking of its forces and society to develop innovative solutions to problems. The key here is experimentation and the ability to embrace failure as a way to learn and grow. ${ }^{17}$

Increased interconnectedness and globalisation offers military forces new opportunities to build and strengthen relationships. ${ }^{18}$ By taking a proactive stand towards achieving increased partnership and cooperation NATO Forces could better address the emerging multidimensional threats. ${ }^{19}$ To help balance hard and soft power, military forces should also improve upon their ability to coordinate a wide network of trusted relationships and partnerships with other international organisations around the globe. This would serve to increase situational awareness, to help ensure regional security, deter conflict, and deescalate conflict situations. ${ }^{20}$

Increased complexity, rapid changes in the security environment, and advances in awareness may create opportunities for military forces to address challenges and provide a stabilising presence in an unstable world. The capacity of military forces to respond to global events in a timely manner enables management of emerging issues which pose a threat to the security of territory and populations. Military forces may also have more

15 Ibid.

16 Ibid.

17 Ibid.

18 NATO-ACT, Strategic Foresight Analysis 2015 Update Report, http://www.act.nato.int/strategic-foresightanalysis-2015-report, (November 2, 2016); NATO-ACT, Strategic Foresight Analysis 2013, http://www. act.nato.int/futures-ws-1 (November 2, 2016); NATO-ACT, Strategic Foresight Analysis 2017, Currently under Development.

19 NATO-ACT, FFAO Bydgoszcz, Poland Conference Report 2016, http://www.act.nato.int/futures-ws-5, (November 2, 2016).

20 Ibid. 
opportunities to engage in a wide array or activities, deter and prevent conflicts, or help resolve conflicts, all of which could change the future security environment for the better. Additionally, NATO Forces in the future may find themselves in a supporting role to assist non-traditional partners in addressing the root causes of instabilities. ${ }^{\mathbf{2 1}}$

NATO Forces will likely have many opportunities in the future to help influence the human aspects of conflict. NATO Forces will be able to seize upon these opportunities if they are able to develop and adopt a mind-set that recognizes that, even in our technological age, war is primarily a human endeavour. Properly cultivated and applied, this mind-set could serve to improve how the forces visualize the environment and interact with relevant actors within the context of the situation. ${ }^{22}$

\section{CONCLUSION}

Overall, the future security environment through 2035 and beyond will likely be increasingly complex and both present challenges and offer opportunities to the NATO's military forces. The analysis of the future security environment indicates that the NATO's military forces will likely face challenges that could unfold in an exponentially accelerated and increasingly complex fashion. A wide variety of drivers could lead to instability situations resulting in the Alliance's decision to employ military forces. However, the NATO's military forces could seize many opportunities in the future. These include building and strengthening relationships, addressing emerging challenges, capitalising on innovative technology and ideas to maintain the military edge, and understanding the human aspects of the conflict. To keep the operational edge today and in the future, NATO joint forces and partners may need to evolve, adapt, and innovate continually to improve their ability to act together comprehensively across all domains to communicate and achieve the political-military objectives of the Alliance.

The views expressed in this article are the author's own and do not represent the views of the U.S. Army, NATO, the Department of Defense, or the U.S. Government.

21 Ibid.

22 U.S. Joint Concept for Human Aspects of Military Operations, http://nsiteam.com/social/wp-content/ uploads/2017/01/20161019-Joint-Concept-for-Human-Aspects-of-Military-Operations-Signed-by-VCJCS. pdf (April 10, 2017). 
Author: $\quad$ Aaron Bazin, Psy.D., MBA, is career Army officer with over 20 years of leadership and experience at the combatant command level, NATO, and the institutional Army. Aaron was the lead-planner for four numbered contingency plans between 2009 and 2012, and has operational experience in Pakistan, Afghanistan, Iraq, Jordan, Kuwait, Bahrain, and UAE. Aaron holds a Doctorate in Psychology in specializing in conflict resolution. He also is the author of the new book, Think: Tools to Build Your Mind.

How to cite:

BAZIN, Aaron. The Future Security Environment: An Emerging View. Vojenské rozhledy. 2017, 26 (5), 101-109. ISSN 1210-3292 (print), 2336-2995 (on-line). Available at: www.vojenskerozhledy.cz 


\section{CONTENTS}

Institutionalisation of the Analytical Support Function to Ensure Credibility of Defence Management - Canada, Norway, Sweden and NATO Case Study

Josef Procházka

The Internationalization of Conflicts: Theoretical Background, Conceptualization, and Contemporary Middle-East Region Josef Kraus

Military Scenario Development

Marius Titi Potirniche

Czech Defence Policy - Critical Assessment and Recommendations

Josef Procházka, Lukáš Dyčka

Landmarks in Analysing Contemporary Conflicts: Between Tradition and the Need for Innovation

Alexandra Sarcinschi

Czech Foreign Fighters in the Ukrainian Conflict: Legal Aspects and

Propagandist Use

Miroslav Mareš

Typology and Analysis of Armed Conflicts

Richard Stojar

The Future of Military Cooperation in Central Europe

Gunther Hauser

The Future Security Environment: An Emerging View 


\section{OBSAH}

Institucionalizace funkce analytické podpory pro potřeby důvěryhodného

rízení obrany - případová studie Kanada, Norsko, Švédsko a NATO

Josef Procházka

Internacionalizace konfliktů: Teoretické pozadí, konceptualizace a oblast současného Středního východu

Josef Kraus

Tvorba vojenských scénářů

Marius Titi Potirniche

Česká obranná politika - kritické hodnocení a doporučení

Josef Procházka, Lukáš Dyčka

Mezníky analýzy současných konfliktů:

mezi tradicí a potřebou inovace

Alexandra Sarcinschi

Čeští zahraniční bojovníci v ukrajinském konfliktu:

právní aspekty a využití v propagandě

Miroslav Mareš

Typologie a analýza ozbrojených konfliktů

Richard Stojar

Budoucnost vojenské spolupráce ve střední Evropě

Gunther Hauser

Budoucí bezpečnostní prostředí: Nový pohled 


\section{Časopis VOJENSKÉ ROZHLEDY}

čtvrtletník

Vydává:

Ministerstvo obrany České republiky, Tychonova 1, 16001 Praha 6 - Dejvice

Vydávající instituce:

Univerzita obrany, Kounicova 156/65, 66210 Brno

IČo: 60162694

Vojenské rozhledy Mimořádné číslo / 2017

Ročník: XXVI. (LVIII.)

Datum předání do tisku: 16. 10. 2017

Rož̌iřuje:

OKP MO, distribuce, Rooseveltova 23, 16105 Praha 6

Olga Endlová, tel. 973215 563, endlovao@army.cz

Redakce:

Mgr. Martin Doleček, telefon: 973442588

E-mail: vojenskerozhledy@unob.cz

\section{Redakční rada:}

Ing. Vojtěch Němeček, Ph.D. (předseda), PhDr. Miloš Balabán, Ph.D., doc. Mgr. Oldřich Bureš, M.A., Ph.D., doc. PhDr. Felix Černoch, CSc., Luboš Dobrovský, Mgr. Lukáš Dyčka, doc. PhDr. Jan Eichler, CSc., Ing. Jiří Halaška, Ph.D., plk. doc. Ing. Vladan Holcner, Ph.D., Ing. Karel Janáč, prof. Ing. Aleš Komár, CSc., PhDr. Tomáš Kopečný, brig. gen. Ladislav Košner, CSc., Mgr. Josef Kraus, Ph.D., plk. Ing. Tomáś Novotný, Ph.D. MSc., Mgr. Martin Riegl, Ph.D., Ing. Ján Spišák, Ph.D., RNDr. Pavel Štalmach MBA, Mgr. et Mgr. Lukáš Tichý, Ph.D.

\section{Tajemník redakční rady:}

Ing. Vladimír Karaffa, CSc.

Sídlo redakce: Kounicova 65, 66210 Brno

Adresa pro zasílání pošty:

Vojenské rozhledy - redakce, Kounicova 156/65, 66210 Brno

Časopis Vojenské rozhledy v elektronické podobě naleznete na:

http://www.vojenskerozhledy.cz/

\section{Časopis je evidován:}

- v evropské databázi ERIH PLUS,

- v seznamu recenzovaných neimpaktovaných periodik vydávaných v České republice

- v mezinárodní databázi Index Copernicus Journals Master List 2015

- v katalogu Národní knihovny České republiky

- v databázi Central and Eastern European Online Library GmbH (CEEOL)

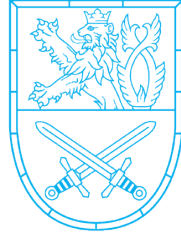

Grafická úprava: Adéla Zemanová

Tiskne: VGHMÚŕ Dobruška

Evidenční číslo: MK ČR E 6059

Identifikační číslo: ISSN 1210-3292 (print), ISSN 2336-2995 (on-line)

doi: 10.3849/2336-2995 